\title{
Em torno de uma sindicância judicial extraordinária: \\ o processo da comarca de Meda (1850)
}

\section{Around an extraordinary judicial investigation: the Meda county process $(\mathbf{1 8 5 0})$}

\author{
Isabel GRAES \\ Professora Auxiliar da Faculdade de Direito \\ Universidade de Lisboa \\ Isabel.Graes@tcontas.pt
}

Recibido: 5 de noviembre de 2013

Aceptado: 7 de enero de 2014

\begin{abstract}
RESUMEN
Según el modelo existente en los siglos anteriores, el estatuto de la magistratura del Ochocientos continua contemplando la práctica de investigar y fijar responsabilidades en la conducta profesional de los magistrados y demás funcionarios judiciales, contra los cuales son instaurados procesos y aplicadas penas, en nombre de la justicia, pretendiendo la legislación vigente controlar de modo integral la actividad judicial e innovando al introducir los consejos disciplinarios.
\end{abstract}

PALABRAS CLAVE: Juez, justicia, liberalismo portugués, residencia, pena, responsabilidad, consejo disciplinario.

\begin{abstract}
Following the previous centuries existing model, the practice of investigating and accountable professional behaviour of judges and other court officials was still contemplated on the $19^{\text {th }}$ century judiciary status. These practices put in place processes and penalties imposed on behalf of the justice, giving the legislation intended to integrally consider the judiciary to introduce innovative activity and the disciplinary councils.
\end{abstract}

KEYWORDS: Judge, justice, Portuguese liberalism, residence, grief, responsibility, discipline council.

\section{RÉSUMÉ}

Selon le modèle existant dans les siècles précédents, le statut de la magistrature du XIX ${ }^{e}$ siècle a continué à viser la pratique de l'enquête et la responsabilité sur la conduite professionnelle des juges et autres fonctionnaires de la cour. Des processus et des sanctions ont été mis en place au nom de la justice, avec l'appui d'une législation destinée à examiner intégralement le système judiciaire et a y introduire l'innovation des conseils de discipline.

MOTS CLÉ : Juge, justice, libéralisme portugais, résidence, peine, responsabilité, conseil de discipline. 


\section{ZUSAMMENFASSUNG}

Dem Modell vergangener Jahrhunderte folgend behalten die Statuten der Magistratur von Ochocientos die Praxis bei, das standesrechtliche Verhalten der Richter und der übrigen Gerichtsbeamten zu untersuchen und diese zur Verantwortung zu ziehen. Damit sind Prozesse und verhängte Strafen im Namen der Justiz verknüpft, die das Gesamtbild des Justizhandelns berücksichtigen und sogar Standesgerichte einführten.

SCHLÜSSELWÖRTER: Richter, Justiz, Portudiesischer Liberalismus, Residenz, Zusammenschluss in Berufsverbänden, Strafe, Verantwortlichkeit, Disziplinargericht.

SUMÁRIO: Apresentação. Introdução. I. O processo de sindicância na primeira metade de oitocentos. 1. Regime jurídico aplicável. 2. Regras constantes do Decreto de 25 de Setembro de 1844. 3. Os conselhos disciplinares 4. Natureza jurídica do processo de sindicância. 5. Penas comummente aplicadas. 6. As sindicâncias extraordinárias. 7. Outras situações. 7.1. Erros de ofício e crimes. 7.2. Correições realizadas a funcionários judiciais II. O caso de Meda, 1850 1. José Januário Teixeira Leite de Castro: breves dados biográficos. 2. A sindicância judicial extraordinária. 2.1. A denúncia e o processo de averiguações. 2.2. A sindicância ou residência extraordinária. III. Conclusão. IV. Apêndice documental.

\section{Apresentação}

A regulação do poder judiciário foi uma das temáticas que se destacou desde o alvor da segunda década de oitocentos quer na oratória parlamentar ${ }^{1}$ quer na doutrina. Muito embora permaneçam alguns conceitos e algumas estruturas do período absolutista sejam ainda adoptadas, o que revela uma certa continuidade no regime vigente, o novo estatuto jurídico da magistratura e a estrutura arquitectónica que se pretende delinear tenderá a ajustar-se ao novo ideário. Nesta circunstância encontra-se a fiscalização e responsabilização do corpo judiciário enquanto sinónimo da recta aplicação da justiça, assunto que reveste a maior importância ao tocar numa das pedras fundamentais do pensamento jurídico oitocentista, ou seja, a independência do poder judiciário enquanto poder político.

O modelo, como veremos, não é inovador, nem tampouco poderemos dizer que as medidas sancionatórias que são tomadas se tornam mais acintosas. Aliás, a julgar

\footnotetext{
${ }^{1}$ A este respeito diz Borges de Carneiro: ... os magistrados prevaricão, e a razão de prevaricarem he terem a certeza de que hão-de escapar da pena. E continuava o mesmo deputado: ... a administração da justiça chegou ao estado que todos sabem. O corpo todo da magistratura he o mais respeitável, mas há membros discalos que a desacreditão; as queixas das partes não infamão a magistratura, de certo não são ellas que a desacreditão, são as Auctoridades superiores, que não castigam as inferiores; estas he que fazem reflectir o vicio de alguns membros no corpo todo; o que infama a magistratura, he chegar um secretario de estado a não castigar os ministros que não cumprem os seus deveres e castigallos asperamente.(...) muitos dos magistrados querem encobrir seos collegas, muitas das partes queixão-se das violencias dos magistrados; porem os magistrados superiores encobrem estas violencias, e o que he mais ainda por cima querem que as partes fiquem reputadas calumniadores... (discurso proferido na Câmara dos Deputados de 1 de Junho de 1821, fls. 1.084-1.085.
} 
por um leque de críticas que caracterizará toda a centúria, é invocada, sem pudor, uma possível tendência para a desresponsabilização legitimada ${ }^{2}$, ou mesmo impunidade fundada num proteccionismo corporativo já que sindicantes e sindicados saíam ambos da magistratura ${ }^{3}$.

Se a crítica é constante não podemos daqui extrair que os processos de sindicância rareiem até porque ao consultarmos os fundos arquivísticos do Ministério dos Negócios Eclesiásticos e de Justiça e do Ministério do Reino existentes no Arquivo da Torre do Tombo, verificamos que os exemplos documentais e os episódios ocorridos são significativos. No entanto, pouquíssimos são os casos em que é possível proceder a uma reconstituição integral do processo, de modo a conhecer a história da personagem sindicada e os incidentes que conduziram ao processo de averiguações e à sindicância judicial de que foi alvo. Na maioria dos casos apenas se conhece o teor de algumas denúncias infundadas que acabam por não ter qualquer consequência, ou ainda breves notas de desfecho apenas com a indicação da pena disciplinar que foi aplicada pelos respectivos tribunais da Relação ${ }^{4}$.

O caso que nos propomos apresentar resulta da análise dos processos de averiguações e de sindicância que são instaurados ao bacharel em Leis, José Januário Teixeira Leite de Castro, juiz de Direito na comarca de Meda nos anos de 1849-51. Destacámo-lo, não só pela sua completude, uma vez que permite a reconstituição daqueles processos, mas sobretudo, pela possibilidade de os podermos conjugar ou integrar no cursus honorum do magistrado cuja conduta foi apreciada.

\section{Introdução}

... por confiarmos de algumas pessoas que nos sirvam bem e fielmente, $e$ como cumpre a nosso serviço e bem da justiça, descargo de nossa consciência e proveito de nossa fazenda, os encarregamos de alguns oficios de justiça, ou da nossa fazenda, e assi por lhes fazermos mercê (a qual porém lhes não faríamos, posto que boa vontade lhes tenhamos, se não fosse a confiança, que neles temos), e depois de os assim termos encarregados nos tais oficios, vêm às vezes à nossa notícia, que os não servem como são obrigados, e conforme a confiança, que neles tínhamos, quando dos tais ofícios os provemos. E posto

\footnotetext{
${ }^{2}$ Por affento (n. $\left.{ }^{\circ} 58\right)$ da Casa da Supplicaçaõ de 28 de novembro de 1634 ficaraõ os Dezembargadores abfolvidos da refponfabilidade. Por eftillo (in João Martins da Cofta: Eftillos da Cafa da Supplicaçaõ, Olifipone, 1692, p. 188) da Cafa da Supplicaçaõ a sentença condenatória em cuftas contra juiz inferior, tem fempre a claufula expreffa, ou tacita de poder fer embargada dentro em trinta diasdepois da fua notificaçaõ. Por ordenaçaõ do livro I, tit. 48, \$15. o advogado com procuraçaõ geral naõ é refponfavel a feu cliente do pejuizo, que lhe caufa (Rocha Peniz, Elementos da pratica formularia ou breves ensaios sobre a praxe do foro portuguez escritos no anno lectivo de 1807 para 1808, edição póstuma, de 1816, tomo I, divisão I, titulo II, §§9-11 pp. 4-5, Regia Typografia Silviana).

${ }^{3} \mathrm{Vd}$. nota ${ }^{\mathrm{0}} 2$.

${ }^{4}$ Nestas circunstâncias se situam os processos instaurados também a Leite de Castro, em 1845 e 1847.
} 
que nas coisas, que assim dos sobreditos sabemos, e que à nossa notícia vem, às vezes não há provas tão claras, porém há quanto basta para sermos certo, que somos deles mal servidos, e eles errarem nos ditos oficios, de maneira que será mais serviço de Deus e nosso serem-lhes tirados que deixá-los estar neles.

Pelo que, e por outros respeitos que nos movem, de muito serviço de Deus e nosso bem da justiça e governo de nossos reinos e senhorios, determinamos, que quaisquer oficios, que dermos, assim da justiça, como da nossa fazenda, ou de qualquer outra sorte e qualidade que seja, quando quer que nós soubermos, e nos certificarmos em nossa consciência que alguns dos ditos oficiais nos servem neles mal e fazem o que não devem, ou danificam e roubam a nossa fazenda, lhos possamos tirar e dar a quem nossa mercê for, sem por isso lhes sermos em obrigação alguma, assim do foro da consciência, como no foro judicial, para por isso haverem de demandar nosso procurador, sem requerer a nós satisfação, porque de todo os excluímos (OF, 1.99).

Todos os magistrados e officiaes de justiça serão responsáveis pelos abusos de poder e pelos erros que commetterem no exercício dos seus empregos (art. $196^{\circ}$ da Constituição de 1822).

Ao longo da sua carreira judiciária, o magistrado não se encontra isento de qualquer responsabilidade. Por este motivo, é, periodicamente, apreciada a sua conduta assim como a do respectivo funcionário que o coadjuvará, através de processos de sindicância judicial ou residência.

A sindicância diz-se ordinária ao ser realizada após a conclusão do período da judicatura, o qual oscila, ao longo de oitocentos, entre três, quatro e seis anos ${ }^{5}$ e na sequência da transferência do referido magistrado de uma para outra comarca ${ }^{6}$. Todavia, sempre que ocorram factos extraordinários que mereçam a devida averiguação e apreciação, é desencadeada uma sindicância extraordinária, por determinação do Poder Executivo.

O objectivo da sindicância ordinária reside na apreciação do efectivo cumprimento dos deveres que são impostos por lei ao magistrado; sendo analisado, entre outros aspectos, a sua probidade e honestidade indispensáveis ao bom desempenho do cargo, ao mesmo tempo que se procura obstar à prática de abusos e prevaricações.

Se no decorrer da sindicância for dada a conhecer a prática de algum crime ${ }^{7}$ e de erros de ofício ${ }^{8}$, já que sobre estes não decorre a sindicância ordinária, o seu conhe-

\footnotetext{
${ }^{5}$ Cfr. Decreto de 25 de Setembro de 1844, art. $3^{\circ}$ da Lei de 18 de Agosto de 1848 , o art. $4^{\circ}$ da Lei de 21 de Julho de 1855 e o art. $11^{\circ}$ do Decreto n. ${ }^{\circ} 3$, de 29 de Março de 1890.

${ }^{6} \mathrm{Cfr}$. art. $1^{\circ}$ da Lei de 31 de Outubro de 1840 que vem regulamentar o art. $127^{\circ} \S$ único da Constituição de 1838; o art. 20\% 10 e 89 $9^{\circ}$ da Novíssima Reforma Judicial e o Decreto de 1 de Agosto de 1844.

${ }^{7}$ Cfr. ainda OF, I. C. pr. e $\$ 2$.

${ }^{8}$ Entendem-se por erros de ofício aqueles que são cometidos na matéria que se professa ou no cargo que se exerce, por engano, descuido, ignorância ou inaptidão (art. erros de ofício, in Diccionario Contemporaneo da Lingua Portugueza, F.J. Caldas Aulete e António Lopes dos Santos, com prefácio de Basilio de Castelbranco, Livraria de A.M. Pereira, Lisboa, p. 648).
} 
cimento ficará sujeito ao disposto no art. $89^{\circ}$ da Novíssima Reforma Judiciária (NRJ). Importa frisar que a residência não exclui ainda a possibilidade de se recorrer para instâncias superiores com vista à correcção de actos processuais.

Em momentos que não os de final de judicatura, podem ser desencadeadas as sindicâncias extraordinárias que terão por objecto actos indevidos praticados por magistrados e, subsequentemente, pelos funcionários judiciais que com eles exerçam funções, os quais decorrem de denúncia ou informação prestada por outras autoridades, mas que não podem ser confundidos com erros de ofício.

Deste modo, a par da sindicância, são realizadas as correições, isto é, a investigação aos cartórios dos juízos e, subsequentemente, aos funcionários judiciais.

Em suma, a responsabilidade dos funcionários poderá ser apurada em termos judiciais e administrativos, dizendo esta última respeito à responsabilidade disciplinar?

\section{O processo de sindicância na primeira metade de oitocentos 1. Regime jurídico aplicável}

Os procedimentos que, sumariamente, descrevemos não são, como referimos, uma novidade do sistema liberal, pois já antes eram sindicados os magistrados judiciais ${ }^{10}$ como decorre das Ordenações do Reino (OF, livro I, tit. LX ${ }^{11}$ ) e do disposto no Alvará de 8 de Fevereiro de 1775, que veio alterar os decretos de 18 e 26 de Janeiro de 1635, o qual seria, por sua vez, revogado pelo Decreto de 17 de Julho de $1778^{12}$, repondo então em vigor as disposições seiscentistas ${ }^{13}$.

Este é o regime em vigor até à Lei de 28 de Novembro de $1840^{14}$, cujo art. $8^{\circ}$ vem restabelecer as sindicâncias ordinárias ${ }^{15}$ para os juízes ordinários, de paz ${ }^{16}$ e eleitos. ${ }^{17-18}$

${ }^{9}$ Vd. A.L. Guimarães Pedrosa, Curso de ciência da administração e direito administrativo, segunda edição, Coimbra, Imprensa da Universidade, 1908, I vol. p.289.

${ }^{10}$ Eram, igualmente, sindicados os ouvidores e corregedores, nos termos da compilação filipina (Livro I, títulos XLIX e LVIII) e dos arts. $193^{\circ}$ e $213^{\circ}$ da $2^{\mathrm{a}}$ Parte da Reforma Judiciária de 1837. Vd. ainda os arts. $85^{\circ} / 10$ e $110^{\circ}$ da Novíssima Reforma Judiciária, a Portaria de 21 de Julho de 1883 e o art. $3^{\circ}$ do Decreto n. ${ }^{\circ}$ 5, de 29 de Março de 1890.

${ }^{11}$ Sobre os erros de ofício cometidos por julgadores e outros officiciaes, $v d$. titulo C, pr. e $§ 1$ do Livro I das OF.

${ }^{12}$ As sindicâncias extraordinárias feitas aos juízes ultramarinos encontravam-se reguladas pelos Decretos de 21 de Setembro de 1668, 1 de Abril de 1677 e 11 de Março de 1732, para o período anterior a oitocentos, sendo, posteriormente, revogado pelos Decretos de 27 de Dezembro de 1852, 8 de Maio de 1855, 21 de Dezembro de 1882 e 12 de Fevereiro de 1891, pela Lei de 20 de Junho de 1866.

${ }^{13}$ Cfr. ainda o Alvará de 14 de Abril de 1785.

Sobre processos de sindicância anteriores a 1840, vd. a título exemplificativo o Fundo do Desembargo do Paço, Repartição da Corte, Estremadura e Ilhas, maços 1602-1652, in IANTT.

${ }^{14}$ In DG n. ${ }^{\circ} 289$.

${ }^{15} \mathrm{Cfr}$. art. $8^{\circ} \S 3$ da Lei de 28 de Novembro de 1840.

${ }^{16} \mathrm{Cfr}$. arts. $126^{\circ}$ e $139^{\circ}$ da Novíssima Reforma Judicial.

${ }^{17} \mathrm{Cfr}$. Projecto de Regulamento Disciplinar para os juízes, empregados de justiça e agentes do Ministério Público apresentado pelo governo na sessão da Câmara dos Deputados de 19 de Novembro de 1840. 
Ou seja, findo o período de judicatura de dois anos ${ }^{19}$ caberia ao Governo designar os delegados do procurador régio em exercício de funções junto do Supremo Tribunal de Justiça ou das Relações ${ }^{20}$ para nos julgados em questão, após efectuadas as competentes requisições, ser examinado se da análise dos feitos crimes ou em quaisquer papeis e livros existia motivo de culpa contra os juízes a sindicar. De igual modo, todas as participações e queixas de crime assim como as denúncias de erros de ofício cometidos pelos juízes no exercício das suas funções que fossem recebidas pelos delegados do Ministério Público, deveriam ser transmitidas, de imediato, ao Poder Executivo ${ }^{21}$, o qual desencadearia os respectivos procedimentos legais com vista à resolução daquelas irregularidades ou mesmo ilegalidades.

Frise-se ainda que para conhecerem dos crimes praticados pelos juízes eleitos e pelos subdelegados do Procurador Régio, no exercício de funções e fora delas, eram competentes os juízes de direito, ainda que sem a intervenção do júri ${ }^{22}$.

\section{Regras constantes do Decreto de 25 de Setembro de 1844}

O diploma promulgado em 1840 seria revogado pelo polémico Decreto de 1 de Agosto de $1844^{23}$ regulamentado pelo Decreto de 25 de Setembro de $1844^{24}$, tendo o

Posteriormente, na sessão n. ${ }^{\circ}$ 17, de 20 de Março de 1843, seria apresentada uma proposta de lei sobre conselhos disciplinares, cuja jurisdição disciplinar ou de censura tinha por objecto a advertência e repressão das faltas dos juízes, as quais não tendo a qualificação de crimes, ou de erros de oficio, revelam o esquecimento e abandono do zeloso cumprimento dos deveres dos juízes no exercício das suas funções, com grave dano da regular administração da justiça (art. $\left.1^{\circ}\right)$. Para este efeito deveriam ser criados, no STJ e nas Relações civis e comercial, conselhos disciplinares com competência para conhecer e corrigir as faltas de omissão e comissão expostas no artigo $1^{\circ}\left(\operatorname{art} .2^{\circ}\right)$, assim como das faltas dos juízes conselheiros, juízes das relações civis e comercial (art. $3^{\circ}$ ) e dos juízes de direito e ordinários do respectivo distrito judicial (art. $4^{\circ}$ ).

Vd. ainda os arts. $5^{\circ}, 6^{\circ}$ e $10^{\circ}$ do mesmo diploma assim como a Portaria de 20 de Outubro de 1840 , o art. $101^{\circ} 4 \S 1$ e 2 da NRJ, a Circular de 18 de Dezembro de 1841 e a Portaria de 19 de Abril de 1842. ${ }^{18}$ Sobre a questão da responsabilidade dos funcionários públicos em geral, cfr. Projecto n. ${ }^{\circ} 111$ apresentado e discutido na sessão da Câmara dos Deputados, em 6 de Março de 1823.

${ }^{19} \mathrm{Cfr} . \S 1$.

${ }^{20} \mathrm{Cfr}$. arts. $1^{\circ}$ e $15^{\circ}$ do Decreto de 25 de Setembro de 1844. A Circular de 16 de Outubro de 1845 determinaria que ainda que fossem competentes os juízes de direito e seus substitutos para, nos termos dos arts. $1030^{\circ}, 1228^{\circ}$ e $1236^{\circ}$ da NRJ, conhecerem dos crimes cometidos, tanto no exercício de funções como fora dele, pelos juízes eleitos, de paz e ordinários, não deveriam intervir os magistrados das comarcas a que pertencessem os arguidos, de modo a que não ficassem prevenidos, como julgadores que podem ser dos acusados devendo o Conselheiro Presidente da Relação de Lisboa ouvi-los directamente havendo os esclarecimentos que forem indispensáveis dos juizes ordinários dos julgados cabeças de comarca; e quando destes se tratar, dos seus substitutos. Vide ainda a Circular de 14 de Dezembro de 1848. Para sindicar os juízes ordinários ou de paz seriam nomeados os delegados do procurador régio.

${ }^{21}$ Idem.

${ }^{22} \mathrm{Cfr}$. $\$ 2$.

${ }^{23}$ In DG n. ${ }^{0} 187$.

${ }^{24}$ In DG n. ${ }^{\circ} 230$. 
legislador disposto que para o exercício das funções de juiz sindicante deveriam ser nomeados no continente e ilhas adjacentes, magistrados judiciais de categoria igual ou superior àquela que era detida pelo sindicado, o que implicaria que poderiam ser designados magistrados judiciais e magistrados superiores do Ministério Público.

Após a nomeação do juiz sindicante, era oficiado o Governador Civil do Distrito Administrativo a que pertencesse a comarca do juiz de direito que iria ser sindicado, que deveria diligenciar no sentido de serem, de imediato, disponibilizados os meios materiais necessários para a acomodação do juiz sindicante (art. $1^{\circ} \S$ único do Decreto de 25 de Setembro de 1844).

Este último, ao receber a ordem de sindicância ou residência, deveria informar o juiz sindicado, indicando a data de início das diligências, para que aquele pudesse atempadamente sair da comarca, deixando, em exercício de funções, um dos seus substitutos. ${ }^{25-26}$

Certo de que o juiz sindicado saíra da comarca e de que todos os meios materiais tinham sido disponibilizados ${ }^{27}$, o juiz sindicante faria divulgar a realização da residência em todos os julgados da comarca por meio de editais, cuja afixação ficava sob a responsabilidade das autoridades administrativas, de modo a que toda a pessoa que tiver razão de queixa ou de agravo contra o juiz sindicado, se apresente a ele Sindicante, durante a residência para os fins convenientes (art. $3^{\circ}$ do Decreto de 25 de Setembro de 1844$)^{28}$.

O processo de residência ordinária começava pela autuação das ordens originais para a sindicância e pela declaração do período de tempo que duraria sendo tomado em atenção o período desde o dia da abertura até ao encerramento (art. $5^{\circ}$ do Decreto de 25 de Setembro de 1844), não podendo extrapolar o prazo de um mês, a contar da data de início, excepto em casos muito excepcionais, os quais dependiam de autorização prévia do governo (art. $10^{\circ}$ do Decreto de 25 de Setembro de 1844).

As diligências incidiriam no exame dos processos pertencentes ao tempo em que o sindicado serviu ${ }^{29}$, dando preferência aos feitos crimes, da Fazenda Nacional e orfanológicos; assim como eram examinados os livros dos cartórios do mesmo juízo de direito, podendo ser exigidas aos escrivães quaisquer certidões, as quais seriam certificadas pelo escrivão da sindicância ${ }^{30}$. Quando de tais averiguações resultasse motivo de culpa ao sindicado deveriam ser feitos os exames judiciais que fossem necessários e dadas todas as providências que se julgasse próprias, de modo a não alterar

\footnotetext{
${ }^{25}$ Cfr. ainda o art. $2^{\circ}$ do Decreto de 25 de Setembro de 1844.

${ }^{26} \mathrm{Cfr}$. as Circulares de 16 de Outubro de 1845 e de 14 de Dezembro de 1848.

${ }^{27}$ A respeito do escrivão da sindicância, $v d$. art. $4^{\circ}$ do Decreto de 25 de Setembro de 1844.

${ }^{28} \mathrm{Vd}$. Alvará de 14 de Abril de 1785 e os arts. $891^{\circ}$ e $892^{\circ}$ da Novíssima Reforma Judiciária.

${ }^{29}$ Note-se que, não só é sindicado o juiz de direito mas também se estende a averiguação aos actos dos funcionários judiciais que com ele serviam, cfr. ainda primeira parte do art. $9^{\circ}$ do Decreto de 25 de Setembro de 1844.

${ }^{30} \mathrm{Cfr}$. art. $6^{\circ} \S$ único do Decreto de 25 de Setembro de 1844.
} 
o estado dos Feitos, ou dos livros em que fosse descoberto algum crime, ou a subtrair quaisquer provas (art. $6^{\circ}$ pr. do Decreto de 25 de Setembro de 1844). Analisava-se ainda o tipo de ausências da comarca que o magistrado pudesse ter praticado durante o tempo em que exercera funções, ao mesmo tempo que se verificava se tinha procedido, nas épocas marcadas, à realização de audiências gerais e à correição dos empregados de justiça; se tinha recebido peitas ou dádivas de alguém para lhe ser favorável nos seus despachos; se tinha havido empréstimos, se fizera compras ou trocas de algumas coisas com pessoas que perante ele requeressem; se tinha tomado mantimentos ou outros objectos sem os pagar, se o fizera por valor inferior ao que apresentavam; e, por fim, se favorecera algum malfeitor.

No que diz respeito ao funcionário de justiça, importava verificar a sua assiduidade no cartório e nas audiências, inteligência e probidade, o tratamento que conferia às partes, os salários que levava, os livros que escriturava, se pagara os direitos de mercê dos títulos que detinha e se cumpria as ordens do Ministério Público (art. $9^{\circ}$ do Decreto de 25 de Setembro de 1844).

Na circunstância do sindicante receber qualquer participação ou queixa de crimes cometidos pelo sindicado, deveria aceitá-la em conformidade com o disposto no art. $892^{\circ}$ da $\mathrm{NRJ}^{31}$, efectuando, de imediato, as indagações adequadas para obter a demonstração do facto arguido, podendo chamar à sua presença quaisquer pessoas que o conhecessem, as quais deveriam depor a este respeito nos mesmos autos da sindicância ${ }^{32}$ (art. $7^{\circ}$ pr. do Decreto de 25 de Setembro de 1844).

Se antes do final da sindicância, o sindicante entendesse que o Governo deveria tomar, desde logo, alguma medida, informava o Ministro dos Negócios Eclesiásticos e de Justiça, sem que a residência fosse interrompida (art. $12^{\circ}$ pr. do Decreto de 25 de Setembro de 1844). Igualmente, se a boa execução da residência dependesse do apoio das autoridades administrativas, estas poderiam ser convocadas (art. $12^{\circ} \S$ único do mesmo diploma).

Terminadas as diligências, o sindicante enviava ao Ministro dos Negócios Eclesiásticos e de Justiça os autos de residência acompanhados de um relatório circunstanciado, no qual se analisavam, de modo distinto, os actos do juiz de Direito e dos funcionários judiciais (art. $11^{\circ}$ do Decreto de 25 de Setembro de 1844).

Recebidos os autos pelo Ministro dos Negócios Eclesiásticos e de Justiça, este reencaminhá-los-ia à Procuradoria-geral da Coroa, cabendo ao Procurador-geral determinar se deveria proceder-se contra o sindicado. Em caso negativo, seria dada a conhecer esta decisão ao Ministro dos Negócios Eclesiásticos e de Justiça, assim como ao sindicado (art. $14^{\circ} \S 1$ do Decreto de 25 de Setembro de 1844). Em caso afirmativo, eram

\footnotetext{
${ }^{31}$ De igual modo era averiguada a possível cumplicidade existente entre os diversos funcionários judiciais, cfr. arts. $8^{\circ}$ e $9^{\circ}$ do Decreto de 25 de Setembro de 1844.

${ }^{32}$ Sobre a recusa à prestação de depoimento, vd. $\S$ único do art. $7^{\circ}$ do Decreto de 28 de Setembro de 1844.
} 
expedidas as ordens necessárias para que fossem promovidas, pelo Ministério Público, as devidas acções contra o juiz sindicado, o qual doravante poderia ser suspenso das suas funções ${ }^{33}$ por decreto do Governo (art. $14^{\circ} \S 2$ do mesmo diploma).

As sindicâncias extraordinárias, tal como as ordinárias, ficavam sujeitas a determinação governamental, podendo ser aplicadas a qualquer tipo de magistrado, de $1^{\mathrm{a}}$ e de $2^{\mathrm{a}}$ instância ${ }^{34}$, ainda que a lei não o expressasse directamente.

Estas regras seriam mantidas pelo diploma de 25 de Setembro de $1844^{35}$, sendo, igualmente, integradas, no texto da Novíssima Reforma Judiciária, a saber, nos arts. $89^{\circ}, 126^{\circ}$ e $139^{\circ}$.

Quatro anos depois, são introduzidos novos prazos, ainda que a Lei de 18 de Agosto de 1848 mantenha o regime de obrigatoriedade da realização das sindicâncias ordinárias aos juízes de direito de $1^{\mathrm{a}}$ instância (art. $3^{\mathrm{o}} \S 3$ ), o qual continua a ser regulado nos termos do Decreto de 25 de Setembro de $1844^{36}$. Por este motivo, as sindicâncias efectuadas aos juízes de direito de primeira instância deveriam ser sempre realizadas, no prazo de quatro meses $^{37}$, após o termo da judicatura não mais trienal ${ }^{38}$, mas quadrienal ${ }^{39} \mathrm{e}$ sempre que se verificasse a subsequente transferência ${ }^{40}$.

Outras alterações seriam introduzidas pela Lei de 10 de Abril de 1849 revista pela Lei de 28 de Novembro do mesmo ano, ao prever a criação dos Conselhos Disciplinares ${ }^{41}$. Frise-se que é este o regime jurídico que se encontra vigente quando o caso ocorrido na comarca de Meda é apreciado.

Ao longo da segunda metade do século XIX seriam apresentadas novas tentativas de reforma dos diplomas de 1844 e 1848, respectivamente, por Martens Ferrão (28

\footnotetext{
${ }^{33}$ Note-se que a suspensão não tinha obrigatoriamente de decorrer como consequência da decisão de ser accionado judicialmente o magistrado em causa, muito embora, esta fosse a prática mais comum. ${ }^{34}$ Exemplo célebre foi a sindicância aos magistrados da Relação do Porto, efectuada em 1854.

${ }^{35}$ Assim, as sindicâncias ordinárias efectuadas aos juízes de direito de $1^{\mathrm{a}}$ instância deveriam realizar-se logo que estes completassem os três annos de serviço em seus logares ou quando os ditos juizes sejam transferidos para outros logares, como estabelece a Carta de Lei de vinte e oito de Novembro de mil oitocentos e quarenta, art. 8, $\S 3$ e a Novíssima Reforma Judicial, art. $89^{\circ} \xi$ único (Preâmbulo) ${ }^{36}$. Estas regras seriam extensivas aos juízes de paz e aos juizes eleitos logo após o termo dos dois anos de exercício de funções. Esta seria uma diferença introduzida relativamente ao regime vigente até 1840, o qual apenas previa que os magistrados eleitos pelo monarca fossem sindicados.

${ }^{36}$ In DG n. ${ }^{\circ} 230$, de 25 de Setembro de 1844.

${ }^{37} \mathrm{Cfr}$. art. $2^{\mathrm{o}} \S 2$ do Decreto de 1 de Agosto de 1844.

${ }^{38} \mathrm{Cfr}$. Lei de 31 de Outubro de 1840 e art. $127^{\circ}$ da C.1838; art. $20^{\circ} / 10,89^{\circ}$ da NRJ.

${ }^{39} \mathrm{Cfr}$. art. $3^{\circ}$ da Lei de 18 de Agosto de 1848 , cujo prazo aí consagrado seria ampliado para seis anos pela Lei de 21 de Julho de 1855 sendo, posteriormente, mantido pelo Decreto n. ${ }^{\circ} 3$ de 29 de Março de 1890.

${ }^{40} \mathrm{Vd}$. ainda o art. $8^{\circ} \S 3$ da Lei de 28 de Novembro de 1840 e os arts. $89^{\circ}, 126^{\circ}, 139^{\circ}$ e $147^{\circ}$ da NRJ.

${ }^{41} \mathrm{Vd}$. art. $1^{\mathrm{o}}$ do Decreto de 25 de Setembro de 1844. Recorde-se a este respeito o texto do relatório apresentado pelo Ministro dos Negócios Eclesiásticos e de Justiça no ano de 1852, que dá a conhecer que o arbítrio não só presidia aos despachos da magistratura como, muitas vezes, não era alheio às tendências políticas dos pretendentes. Por este motivo, o mesmo relatório datado de 8 de Junho remetia para uma proposta de lei sobre sindicâncias, a qual havia sido já apresentada em 24 de Março de 1852.
} 
de Fevereiro de 186042), Adriano Machado (26 de Abril de 1880 ${ }^{43}$ ) e Veiga Beirão ( 9 de Julho de $1887^{4-45}$ ), pese embora as alterações tenham sido introduzidas apenas pelo Decreto n. ${ }^{\circ} 3$, de 15 de Setembro de $1892^{46}$, já que nenhum daqueles três textos viria a ser aprovado.

\footnotetext{
${ }^{42}$ Nesta proposta era apresentada como novidade a divisão em círculos de sindicância de seis comarcas para cada um dos distritos judiciais das Relações de Lisboa e Porto, compreendendo dois círculos criminais de assentada (art. $5^{\circ}$ ) e sendo a sua periodicidade bienal e trienal.

Criava-se em cada uma das relações de Lisboa e Porto uma secção composta respectivamente por 10 e 15 juízes a cargo da qual fica o serviço das sindicâncias dos juízes e funcionários dos tribunais de $1^{\mathrm{a}}$ instância (art. $1^{\circ}$ ).
}

As sindicâncias ordinárias em cada um dos círculos passariam, então, a ter lugar de dois em dois anos, e de três em três anos logo que as transferências passassem a ser reguladas segundo o artigo $4^{\circ} \S 5$ da Lei de 21 de Julho de 1855, sendo feitas por um dos juízes da secção de segunda instância criada por esta lei (art. $6^{\circ}$ ).

$\mathrm{Vd}$ ainda os arts. $15^{\circ}, 16^{\circ}, 20^{\circ}, 25^{\circ}, 32^{\circ}, 52^{\circ}$ e $54^{\circ}$. O texto desta proposta seria seguido, mais tarde, por Morais de Carvalho.

${ }^{43}$ Adriano Machado, também na qualidade de ministro da justiça apresentaria na sessão da Câmara dos Deputados de 26 de Abril de 1880, uma proposta de lei sob o n. ${ }^{\circ}$ 175-A, onde no seu preâmbulo indica que até hoje o Supremo Tribunal de Justiça não tinha os elementos necessários para consultar com conhecimento de causa as promoções dos juizes, nem o governo os tinha para apreciar o merecimento dos propostos. A inspecção deve supprir esta falta essencial (fl. 1655). Fazendo corresponder as sindicâncias ordinárias ao termo de judicatura (de quatro anos), período em que deveriam ser transferidos os juízes de primeira instância de uma para outra comarca (art. $5^{\circ}$, pr.) e logo depois de feita a primeira transferência geral, e daí em diante, deveria no início de cada quadriénio ser efectuada uma sindicância nas comarcas onde for possivel e especialmente em quinze de cada classe onde acabaram de servir os juízes mais antigos (art. $8^{\circ}$, pr.). A sindicância seria feita nas comarcas de $1^{\mathrm{a}}$ classe por juízes da Relação do distrito, nomeados pelo seu presidente; nas de $2^{\mathrm{a}}$ classe pelos juízes de $1^{\mathrm{a}}$; nas de $3^{\mathrm{a}}$, pelos de $1^{\mathrm{a}}$ ou $2^{\mathrm{a}}$, a quem for menos incómodo, pela razão da distância ou das comunicações (§1).

${ }^{44}$ A mesma proposta tomaria o n. ${ }^{\circ}$ 162-A. Veiga Beirão retomará, parcialmente, o exemplo dado pela legislação de 1849 e cria o Supremo Conselho de Magistratura Judicial para o qual passam as atribuições que competiam ao STJ com respeito à promoção, antiguidade e aposentação dos juízes e à imposição de penas disciplinares. Doravante, os juízes passariam a estar subordinados disciplinarmente ao ministro dos NEJ (art. $22^{\circ}$ ), residindo como critério para a realização das sindicâncias o entendimento da oportunidade e conveniência que o governo ditasse para o momento, devendo ser ouvido, para o efeito, o supremo conselho de magistratura (art. $26^{\circ}$ ) Esta medida pretendia assim salvaguardar o princípio da independência, evitando o total arbítrio por parte do poder executivo face ao Judiciário.

Durante o período da sindicância os magistrados ficavam suspensos do exercício de funções devendo sair da comarca $\left(\$ 2\right.$ do art. $\left.26^{\circ}\right)$.

${ }^{45}$ No ano seguinte, o respectivo parecer da Comissão de Legislação civil apresentado às Cortes em 12 de Março proporia no art. $26^{\circ}$ que as sindicâncias extraordinárias aos actos dos juízes, só poderiam ser determinadas quando houvesse consulta afirmativa do Supremo Conselho de Magistratura Judicial, nos termos do art. $121^{\circ} / 5$ do mesmo projecto de lei. A sindicância poderia ser feita quando o ministro da justiça, uma vez tendo sido informado pelos seus agentes, propusesse a pena disciplinar ao Supremo Conselho de Magistratura Judicial $\left(\operatorname{art} .26^{\circ}\right.$ ) ou quando o juiz processado disciplinarmente, requeresse a investigação dos seus actos, como meio de provar a injustiça das acusações (art. 121\%/5). In Reorganisação judiciaria, Parecer da Commissão de legislação civil apresentado às cortes em sessão de 12 de Março de 1888, Lisboa, Imprensa Nacional, 1888.

${ }^{46}$ In DG n. ${ }^{\circ}$ 209. Este diploma procede à criação do Conselho Disciplinar da Magistratura Judicial, ao 
Ainda que o regime instituído em 1840-44 tenha permanecido inalterado por quase cinco décadas, Martens Ferrão reconhece-lhe logo em 1860 alguns defeitos:

... O primeiro é a natureza da magistratura a que a lei as confia, o segundo é a sua irregularidade. A magistratura do MP é essencialmente fiscal, é verdade; mas esta espécie de fiscalização de que aqui se trata envolve uma operação mista, porque (...) compreende também uma espécie de julgamento. É por isso que o MP tendo um importante papel a representar nas sindicâncias, não pode ser unicamente encarregado delas. É por isso que as actuais sindicâncias são um simples processo informativo, e por isso mesmo quase sempre estéril. Alargar mais nestes objecto a acção do MP seria inverter a sua natureza, e ao mesmo tempo ofender os princípios consignados no nosso código político, que não quer que o poder judicial seja irresponsável, mas quer que seja independente.

O outro grande defeito é a irregularidade das sindicâncias. É da essência da acção fiscal que ela em regra obre sem prevenções para que possa ser equitativa. Porém isto não é possivel quando no decretar-se uma sindicância extraordinária a um funcionário ou tribunal, vai envolvida uma acusação, uma suspeita, um juizo proferido pelo poder executivo que só deverá ter recorrido a esse meio extremo, quando tiver o seu parecer formado acerca da procedência das razões que se lhe ofereceram para crer na culpabilidade do tribunal ou funcionário sindicado. ${ }^{47}$

qual é atribuída competência para ordenar sindicâncias a requerimento do Ministério Público, ou por iniciativa própria (art. $1^{\%} / 3$ ). No entanto, a instauração do processo de sindicância encontrava-se ainda dependente de despacho do Ministro da Justiça e dos Negócios Eclesiásticos, pois o referido Conselho apenas poderia apresentar uma proposta $\left(\operatorname{art.} 4^{\circ}\right)$.

${ }^{47}$ Trata-se da proposta de lei apresentada na Câmara dos Deputados pelo Ministro e Secretário de Estado dos Negócios Eclesiásticos e de Justiça, Alberto António de Morais Carvalho, in DG de 9 de Janeiro de 1861. Desta proposta cabe destacar o teor dos arts. $19^{\circ}$ e $20^{\circ}$ que previam a actuação em todas as sindicâncias de um agente do MP nomeado pelo Governo, função que poderia ser desempenhada pelo delegado do procurador régio da comarca respectiva. Todavia nenhum delegado serviria em sindicância na comarca cujo delegado tivesse servido em sindicância na dele.

Ao magistrado do MP em sindicância pertenceria: examinar os processos e livros relativos à administração da justiça e deduzir por escrito, perante o juiz sindicante, a querela dos factos criminosos ou irregulares que encontrar ou que pelo juiz lhe forem comunicados; promover investigações e exames para prova dos mesmos factos ou de queixas que por qualquer indivíduo lhe fossem feitas; agravar no auto do processo de qualquer indeferimento do juiz sindicante sobre diligências relativas à sindicância; vigiar se o juiz e mais empregados da sindicância haviam cumprido com exactidão o seu dever e informar o Governo, por intermédio do respectivo procurador régio, das irregularidades, faltas ou crimes que notasse. No fim da sindicância deveria proceder à redacção de um relatório que remeteria ao Governo, pela mesma via, expondo o estado da administração da justiça, dos tribunais e o das prisões e o juízo que forma da inteligência e probidade de cada um dos empregados judiciais da comarca, assim como o do magistrado do MP que servisse na mesma comarca, quando este não fosse o próprio sindicante (art. $21^{\circ}$ ).

Ainda sobre a ordem do processo nas sindicâncias, vide arts. $25^{\circ}-49^{\circ}$. Sobre as sindicâncias ordinárias e extraordinárias, vide arts. $54^{\circ}-58^{\circ}$. 
De igual modo, também o Relatório apresentado, em 1854, pelo Ministro dos Negócios Eclesiásticos e de Justiça, Frederico Guilherme da Silva Pereira ${ }^{48}$, ao fazer referência à legislação que contempla o regime jurídico das sindicâncias, frisa que a imposição de a cada transferência ser executada uma diligência com vista à fiscalização da judicatura do magistrado de primeira instância encontrou dificuldades no que diz respeito ao sindicante que somente pode ser escolhido entre os magistrados superiores do Ministério Público, os quais apenas bastam para o serviço que lhes compete fazer junto aos respectivos tribunaes, senão também quanto aos resultados da syndicância, visto como esta dligência é puramente informatória, e não tem carácter algum judicial. ${ }^{49}$ Não obstante estas contrariedades, o mesmo ministro decidiria, face a dois casos específicos, que se procederia à devida sindicância por altura das primeiras transferências que foram feitas, respectivamente a um juiz pertencente ao distrito da Relação de Lisboa e outro ao da Relação do Porto, como o revelam as Portarias de 4 de Outubro de $1853^{50}$, tendo os autos de sindicância, posto que conclusos, sido remetidos à Procuradoria Geral da Coroa.

Importa esclarecer que o diploma de 1892, sem revogar na totalidade os diplomas de 25 de Setembro de 1844, de 18 de Agosto de 1848 e de 10 de Abril de $1849^{51}$ apresenta-se de modo mais completo, incidindo sobre matérias que até então se encontravam dispersas por vários diplomas avulsos, dando um pouco mais de atenção às sindicâncias extraordinárias. Ainda assim, está longe de ser exaustivo. Doravante passam também a ser reguladas as penas a aplicar.

\section{Os conselhos disciplinares}

Estatuída a forma de correição na legislação ordinária de 1840, 1844 e 1848, o legislador de 1849 não só apresentaria a noção de jurisdição disciplinar ou de censura mas também criava os conselhos disciplinares.

Deste modo, por jurisdição disciplinar ou de censura era entendida aquela que tem por fim advertir e corrigir as faltas dos juízes cometidas dentro ou fora do exercício das suas funções e que não tendo a qualificação de crimes ou erros de ofício revelava por parte dos magistrados um esquecimento e desprezo pela dignidade da magistratura e do zeloso cumprimento dos seus deveres $\left(\operatorname{art.} 1^{\circ}\right)^{52}$.

\footnotetext{
${ }^{48}$ In DG n. ${ }^{\circ}$ 82. Frederico Guilherme da Silva PEREIRA, nasce em Monção, em 28 de Abril de 1806 e vem a falecer em Lisboa, em 18 de Janeiro de 1871. É filho de Francisco Xavier da Silva Pereira e de Antónia Josefa de Abreu. Bacharel em Leis (1827), segue a carreira da magistratura, sendo nomeado presidente do Tribunal da Relação de Lisboa, em 1867. Desempenharia as funções de ministro dos Negócios Eclesiásticos e de Justiça, em 1853 e da Fazenda (1855-1856). Deputado nas legislaturas de 1851-52 e 1853-56 e presidente desta Câmara (1853).

${ }^{49}$ In fl. 438.

${ }^{50}$ In DG n. ${ }^{\circ} 235$.

${ }^{51}$ In $\mathrm{DG} \mathrm{n} .^{\circ} 79$.

${ }^{52}$ Recorde-se que de acordo com a disposição constante do art. $14^{\circ}$ da Constituição de 1822 , todos os
} 
Para este efeito, o mesmo diploma criava, junto do STJ e de todas as Relações do continente, um conselho disciplinar composto pelos presidentes dos tribunais em que eram instituídos aqueles órgãos acrescidos de mais quatro dos seus membros, escolhidos sob a forma de sorteio (arts. $1^{\circ}$ e $\left.2^{\circ}\right)^{53}$. Ao primeiro competia o conhecimento dos actos que não fossem erros ou crimes de oficio cometidos pelos membros do Supremo Tribunal e pelos de todos os tribunais de $2^{\mathrm{a}}$ instância. No que diz respeito aos conselhos criados junto das Relações caber-lhes-ia conhecer dos actos praticados pelos juízes de direito de $1^{\mathrm{a}}$ instância, qualquer que fosse ou viesse a ser a sua denominação e dos praticados pelos juízes ordinários do respectivo distrito judicial, desde que não fossem, como referimos anteriormente, erros ou crimes de ofício (art. $3^{\circ}$ ).

A convocação destes conselhos disciplinares era da competência do respectivo presidente depois de recebido o requerimento do agente do MP, ao qual se encontravam apensados todos os documentos remetidos pelo Ministro dos Negócios Eclesiásticos e de Justiça (arts. $3^{\circ}$ e $4^{\circ}$ ).

Findo o processo preparatório ${ }^{54}$, o mesmo Conselho, tendo tomado conhecimento por escrito da posição do agente do MP, deliberaria em conferência particular, sobre a sua competência ${ }^{55}$ ou sobre a aplicação da pena disciplinar $\left(\operatorname{art.~} 7^{\circ}\right)$.

Quando o juiz arguido alegasse, na sua resposta, a incompetência do Conselho, ou invocasse que a falta em apreço deveria ser qualificada como crime ou erro de ofício o que conduzia à instauração dos meios ordinários da querela; ou ainda que a mesma não devia, por sua natureza e qualidade, estar sujeita à jurisdição disciplinar, o Conselho, sobrestando na decisão final, proporia o processo em mesa grande, ou em conferência de todos os membros do tribunal, decidindo unicamente o ponto da competência (art. $8^{\circ}$, pr.)

De outro modo, se o tribunal decidisse que não era caso de apreciação em sede de jurisdição disciplinar, por ser de querela, deveria fazê-lo constar de acórdão, remetendo toda a documentação ao agente do Ministério Público, que deveria agir em conformidade $(\S 1)^{56}$.

Uma vez tomadas as decisões definitivas pelos Conselhos Disciplinares, aquelas deveriam ser comunicadas pelo respectivo presidente à secretaria do MNEJ, seguindo-se a devida publicação no Diário do Governo (art. 14\%).

Ainda que a Lei de 10 de Abril de 1849 tenha previsto a criação destes órgãos, o Relatório da proposta de lei apresentada por Martens Ferrão, em 1860, assim como

empregados públicos serão estritamente responsáveis pelos erros de ofício e abusos do poder, na conformidade da Constituição e da lei.

${ }^{53}$ Em matéria de suspeições, vide art. $4^{\circ}$.

${ }^{54} \mathrm{Cfr}$. arts. $5^{\circ}$ e $6^{\circ}$.

${ }^{55} \mathrm{Cfr}$. arts. $8^{\circ}$ e $9^{\circ}$ do Decreto de 15 de Setembro de 1892.

${ }^{56}$ Quando a incompetência não tivesse sido invocada pelo juiz arguido, tendo decorrido de apreciação do Conselho Disciplinar, as consequências eram em tudo idênticas face ao já exposto (cfr. art. $9^{\circ}$ da Lei de 10 de Abril de 1849). 
o Relatório da Presidência da Relação de Lisboa datado de 1872 e o do Decreto n. ${ }^{\circ}$ 3, de 15 de Setembro de 1892 dão a conhecer que estas disposições nunca foram postas em execução o que levou a que os conselhos disciplinares nunca tenham sido efectivamente instituídos. Por este motivo, o Conselho Disciplinar da Magistratura Judicial seria criado pela primeira vez em $1892^{57}$, mantendo as competências dos órgãos previstos na legislação anterior. Refira-se ainda que, a proposta de Veiga Beirão consagraria também a criação de um Supremo Conselho composto por juízes, colocando-o na dependência do poder executivo, medida que seria, mais tarde, adoptado também pelo já mencionado diploma de 1892 .

Importa recordar que este Conselho, tal como se encontrava estatuído pelo diploma de 1892, deveria ainda proceder a todas as averiguações necessárias e às sindicâncias que entendesse convenientes para indagação da verdade (preâmbulo e art. $1^{\circ}$ /1) podendo impor a sua execução aos presidentes dos tribunais de $2^{\mathrm{a}}$ e $1^{\mathrm{a}}$ instância e requisitar dos magistrados administrativos e demais funcionários, mapas, documentos e quaisquer outras informações ou esclarecimentos (art. 1\%/2), cabendo-lhe ainda ordenar ainda a instauração do respectivo processo de sindicância, sem prejuízo da iniciativa do governo, nos termos do art. $1^{\mathrm{o}} / 3$ do mesmo diploma.

Contrariamente ao que sucedia com o regime anterior, o legislador fazia depender da apreciação do Conselho a decisão de dar início ao processo de sindicância extraordinária a um magistrado, conferindo àquele órgão a competência para advertir os magistrados e corrigir as faltas dos juízes cometidas no exercício das suas funções, ou fora delas, as quais não sendo crimes ou erros de ofício, revelavam, como já tivemos a oportunidade de referir, esquecimento ou desprezo da dignidade da magistratura e do zeloso cumprimento dos seus deveres ${ }^{58}$.

Ainda que tenha sido minuciosamente estatuído pelo legislador de $1892^{59}$, este órgão manter-se-ia, mais uma vez, inoperante até à sua extinção operada pelo Decreto de 24 de Outubro de $1910^{60}$. Ou seja, na prática mantém-se o regime vigente à data de 1849 sendo a apreciação casuística feita pelas Relações ${ }^{61}$.

\footnotetext{
${ }^{57} \mathrm{O}$ preâmbulo justificava a criação do presente Conselho como sendo uma medida absolutamente necessária e de que resultará grande utilidade pública e acrescentava em seguida que os conselhos disciplinares, estabelecidos junto das Relações e com attribuições restrictas, não exerceram funcções proveitosas, e a falta de inspecção aos serviços judiciaes tem occasionado inconvenientes (in DG n. ${ }^{\circ}$ 209, de 16 de Setembro de 1892, p. 705).

${ }^{58} \mathrm{Cfr}$. art. $7^{\circ}$.

${ }^{59}$ Cfr. arts. $1^{\circ}, 2^{\circ}, 4^{\circ}$ e $5^{\circ}$ do Decreto n. ${ }^{\circ} 3$, de 15 de Setembro de 1892 e arts. $1^{\circ}-3^{\circ}, 7^{\circ}$ e $23^{\circ}$ do Decreto de 13 de Dezembro de 1892 (in DG n. ${ }^{\circ} 289$ ).

${ }^{60}$ Cite-se ainda que a 30 de Agosto de 1883, tenha sido criado em França o regime disciplinar da magistratura judicial, onde tomaram parte numa discussão famosíssima Waldeck-Rousseau, autor do projecto e Alexandre Ribot, caberia ao Tribunal de Cassation a faculdade de impor as penas a quaisquer magistrados, com a excepção dos jurados comerciais e dos árbitros-avindores.

${ }^{61}$ Sobre o estado das sindicâncias, $v d$. o ofício remetido pelo Procurador Régio José Maria Pereira Forjaz, ao Ministro dos Negócios Eclesiásticos e de Justiça, datado de 20 de Fevereiro de 1858, in Iantt, MNEJ, maço 576/3. Para o período constitucional subsequente, vide os Decretos n. ${ }^{\circ} \mathrm{s} 4172$, de 30 de
} 
Não devemos esquecer que, paralelamente, na primeira década de novecentos seria criado, em 24 de Outubro de 1901, o Supremo Conselho de Magistratura do Ministério Público (SCMMP) ${ }^{62}$ e, em 29 de Novembro de 1901, o Conselho Disciplinar dos Oficiais de Justiça (CDOJ) ${ }^{63}$. Para esclarecer o Governo e orientar os serviços era instituído o Conselho Superior Judiciário (CSJ), em 21 de Setembro de $1901^{64}$, o qual tinha por presidente o Ministro da Justiça e vice-presidente um juiz conselheiro do $\mathrm{STJ}^{65}$. Também a magistratura ultramarina tinha o seu conselho disciplinar próprio ${ }^{66}$.

Abril de 1918 que reorganiza o CSMJ e o CSMMP; 4691, de 23 de Junho de 1918 que reorganiza o CSMJ determinando as suas atribuições quanto às nomeações, transferências e promoções de juízes, bem como determinava que os Presidentes do STJ e das Relações seriam da livre escolha do Governo, sendo escolhidos entre os juízes dos respectivos tribunais e sobre a nomeação e promoção dos oficiais de justiça. Seguir-se-ia o Decreto n. ${ }^{\circ}$ 10734, de 2 de Maio de 1925, que dispunha que a acção disciplinar sobre os magistrados, funcionários e empregados relativamente a infracções disciplinares de carácter político eram da competência do Poder Executivo.

${ }^{62}$ Cfr. Decreto n. ${ }^{\circ}$ 4172, de 30 de Abril de 1918.

${ }^{63}$ Cfr. Decreto n. ${ }^{\circ} 7128$, de 18 de Novembro de 1920.

${ }^{64}$ In DG n. ${ }^{\circ} 214$, de 24 de Setembro. Cfr. Decreto n. ${ }^{\circ} 7725$, de 6 de Outubro de 1921, alterado pelo Decreto n. $^{\circ} 7751$, de 28 de Outubro do mesmo ano e que consagrava o Conselho Superior Judiciário (CSJ) regulando ainda as respectivas atribuições e o Decreto n. ${ }^{\circ} 12260$, de 18 de Setembro de 1926 que sujeita à acção disciplinar do CSJ todos os funcionários do registo civil, predial e notariado. O diploma de 1892 determina que este mesmo conselho seria composto por juízes eleitos, vindo a Lei de 1912 substituir esta forma de recrutamento pela de nomeação governativa. Suceder-lhe-ia o Decreto n. ${ }^{\circ} 4172$, de 26 de Abril de 1918 que optaria, mais uma vez, pela eleição de todos os vogais, tendo o Decreto n. ${ }^{\circ} 5499$, de 5 de Maio de 1919, regressado ao anterior regime. Caberia ao Decreto n. ${ }^{\circ} 11751$, de 23 de Junho de 1926 estabelecer o regime misto de nomeação e eleição para os vogais conselheiros e a eleição para os demais vogais especiais, salvo quando se tratasse de magistrados do MP. Os diplomas seguintes alternariam entre um e outro regime.

A respeito do Conselho Superior da Magistratura Judicial, cfr. a Lei de 12 de Julho de 1912, os Decretos n. ${ }^{\circ}$ 4691, de 23 de Julho de 1918 e 5499, de 14 de Abril de 1919.

A dissolução e substituição do Conselho Superior Judiciário, do Conselho Disciplinar da Magistratura Judicial, do Supremo Conselho da Magistratura do Ministério Público, do Conselho Disciplinar dos oficiais de justiça e do Conselho Superior do Notariado seriam determinadas, mais tarde, pelo art. $8^{\circ}$ do Decreto de 24 de Outubro de 1910, vindo, posteriormente, o Decreto de 6 de Outubro de 1921 a reunir os vários conselhos disciplinares existentes no Conselho Superior Judiciário.

A respeito da reorganização do Conselho Superior da Magistratura do Ministério Público, $v d$. o Decreto n. ${ }^{\circ}$ 4172, de 30 de Abril de 1918 e o Decreto de 29 de Novembro de 1910

${ }^{65} \mathrm{Cfr}$. art. $4^{\circ}$. Vide ainda arts. $5^{\circ}-9^{\circ}$.

${ }^{66}$ Relativamente à magistratura ultramarina e aos funcionários judiciais em exercício de funções naqueles territórios, vide o Regimento da Administração da Justiça Ultramarina de 1894 e o Decreto n. ${ }^{\circ} 10$, de 10 de Janeiro de 1895 (in Diário do Governo n. ${ }^{\circ}$ 10, de 12 de Janeiro). Note-se que os magistrados e funcionários judiciais em exercício de funções nas províncias ultramarinas estavam sob a alçada do Conselho Superior da Magistratura Judicial Ultramarina que deveria proceder à classificação graduada dos candidatos à magistratura judicial e do Ministério Público do ultramar; fixar a antiguidade dos mesmos, efectuar a consultas sobre a aposentação, transferências e sindicâncias, aplicar penas disciplinares aos magistrados judiciais ultramarinos; emitir parecer sobre todos os assuntos de administração da justiça ultramarina, em que fosse consultado pelo Governo e exercer as demais atribuições que pelas leis e regulamentos lhe forem cometidas e que pelo mencionado Regimento pertenciam à Junta Consultiva do Ultramar. 


\section{Natureza jurídica do processo de sindicância}

O processo de sindicância tinha uma natureza meramente informativa e não condenatória ${ }^{67}$, não se tratando, por conseguinte, nem de um processo judicial, nem de um acto de jurisdição contenciosa. Ou seja, com este procedimento pretendia-se apenas apurar a verdade dos factos, devendo o processo, no seu final, ser encaminhado ao representante do Ministério Público que proporia a instauração do respectivo crime, caso se verificasse necessário ${ }^{68}$.

\section{Penas comummente aplicadas ${ }^{69}$}

Pelas faltas e irregularidades cometidas no exercício ou fora do exercício das suas funções, podem ser aplicadas aos magistrados e funcionários judiciais, consoante a gravidade do acto praticado, as penas de advertência, censura, multa, suspensão, colocação no quadro e demissão ${ }^{70}$, as quais não se destinavam exclusivamente a situações de natureza disciplinar ${ }^{71}$.

Pelas faltas disciplinares, eram aplicadas aos magistrados as penas de advertência, censura simples e severa ${ }^{72}$, suspensão e demissão ${ }^{73}$ tendo disposto a este respeito a

${ }^{67}$ Cfr. art. $5^{\circ}$ do Decreto de 25 de Setembro de 1844.

${ }^{68}$ Cfr. Circular de 14 de Dezembro de 1848.

${ }^{69}$ Vide Iantt, MNEJ, maços 329/9, 369/1 e 701/12.

${ }^{70}$ Em termos comparativos, importa enunciar que a Ley de Enjuiciamiento española, de 1870, estabelecia como penas disciplinares: a repreensão simples; a repreensão qualificada; o impedimento de promoção; a privação de soldo; a suspensão de emprego conjugada com a privação de soldo, nos termos do art. $740^{\circ}-752^{\circ}$.

No âmbito do direito português, a proposta de lei de 9 de Julho de 1887 definiria como penas disciplinares, as de censura, repreensão e suspensão temporária (arts. $117^{\circ}-119^{\circ}$ ) que poderiam ser aplicadas ao juiz que sem praticar crime, ou fora dos casos em que poderia ser advertido, multado e condenado nas custas pelos tribunais superiores, faltasse ao cumprimento dos seus deveres profissionais ou cometesse, dentro ou fora do exercício de funções, faltas, que não tendo a qualificação de crimes ou erros de ofício, mostrassem esquecimento e desprezo da dignidade da magistratura e do zeloso cumprimento dos seus deveres (arts. $\left.115^{\circ}-116^{\circ}\right)$.

${ }^{71}$ Note-se que o Código Civil havia declarado nos arts $2401^{\circ}$ e $2402^{\circ}$ que os juízes são irresponsáveis pelos seus julgamentos, excepto quando praticassem crimes, quando forem anuladas as sentenças nos tribunais superiores, se deixar expressamente o direito salvo aos lesados em caso de perdas e danos, ou quando fossem multados e condenados em custas na forma do CPC. Vide ainda os arts. $192^{\circ}, 222^{\circ}, 223^{\circ}$ e $303^{\circ}$ do Código Civil.

Cfr. ainda o art. $126^{\circ}$ do Decreto de 24 de Outubro de 1901.

${ }^{72}$ As penas de advertência e censura são aplicadas em virtude de falhas leves, nos termos do art. $7^{\circ}$ do Decreto de 13 de Dezembro de 1892, podendo também ser aplicadas aos magistrados do MP.

A censura poderia ser simples ou severa, sendo definida como a exprobração formal, que revestiria a forma escrita ou oral, permitindo ainda o legislador a sua cumulação com a pena pecuniária (de $10 \$ 000$ réis a $50 \$ 000$ réis). Vide ainda os arts. $127^{\circ}$ e $131^{\circ}$ do Decreto de 24 de Outubro de 1901.

${ }^{73} \mathrm{Cfr}$. arts. $10^{\circ}-14^{\circ}$ da Lei de 10 de Abril de 1849. A perda do lugar ocorre quando o oficial de justiça: sem motivo justificado, não tome posse no prazo legal, abandone o lugar por mais de 15 dias, renuncie 
Lei de 10 de Abril de 1849, o Código Penal de 185274, o Código de Processo Civil de 1876 e, por último, o Decreto n. ${ }^{\circ}$ 4, de 15 de Setembro de 1892.

Enquanto a censura simples poderia ser aplicada aos juízes ordinários, aos magistrados de primeira e segunda instância e aos membros do Supremo Tribunal de Justiça, devendo ser intimada aos mesmos pelo presidente do tribunal a que pertencessem, estando reunido o respectivo Conselho Disciplinar em conferência particular ${ }^{75}$; a censura severa seria imposta, por meio de acórdão, aos magistrados de primeira instância, os quais seriam intimados pessoalmente, pelo juiz de direito da comarca mais próxima, na presença de dois substitutos e do agente do Ministério Público, na sede da residência do juiz arguido (art. $12^{\circ}$, pr. da Lei de 10 de Abril de 1849).

Nos casos de reincidência em que tivesse, previamente, sido aplicada a pena de censura simples, deveria aquela ser publicada no Diário Oficial. Nos casos de reincidência de censura severa, o magistrado seria suspenso do exercício de funções pelo período de dois a três meses sem vencimento de ordenado, devendo a mesma pena ser imposta em conferência de todo o tribunal (art. $13^{\circ}$ do mesmo diploma de 1849) ${ }^{76}$.

Dos vários tipos de pena que indicámos, o diploma de 1849 consagrava apenas a censura simples e severa, cabendo à legislação penal e, subsequentemente, ao Código de Processo Civil introduzir a pena de multa que poderia ser aplicada de forma simples ou conjugada com outro tipo de pena ${ }^{77}$.

Disciplinarmente, a pena de suspensão decorria da decisão dos presidentes e juízes dos respectivos tribunais desde que se procedesse a audiência prévia e se dessem a conhecer, ao arguido, os motivos da suspensão,${ }^{78}$ sendo invocada a prática de faltas dentro ou fora do exercício das suas funções, que não tendo a qualificação de crimes

ao cargo, aceite emprego, exerça profissão ou assuma qualidade incompatível com o lugar de oficial de justiça e ainda quando por sentença passada em julgado for interditado da administração de seus bens. ${ }^{74} \mathrm{Cfr}$. Livro II, título III, capítulo XIII, artigos $284^{\circ}-323^{\circ}$, a respeito dos crimes públicos praticados pelos juízes bem como os artigos $326^{\circ}$ e $327^{\circ}$ da secção $8^{\circ}$.

${ }^{75}$ Tratando-se de pena aplicada aos magistrados de segunda instância, deverá o presidente do Conselho Disciplinar do STJ expedir a competente ordem do Presidente da respectiva Relação (art. $10^{\circ}$, 1 da Lei de 10 de Abril de 1849). $V d$ ainda o art. $11^{\circ}$ do mesmo diploma.

${ }^{76}$ Todas as decisões finais dos Conselhos Disciplinares deveriam ser comunicadas pelo respectivo Presidente à Secretaria de Estado dos Negócios Eclesiásticos e de Justiça (art. 14º).

${ }^{77}$ São respectivamente as situações consagradas nos arts. $306^{\circ}$ e $308^{\circ} \S 1 \mathrm{CP}$ para o primeiro caso; e o do art. $284^{\circ} \S 2 \mathrm{CP}$, para o segundo em que era conjugada com a pena de suspensão dos direitos políticos por quinze anos; ou ainda com a demissão (arts. $289^{\circ}, 316^{\circ}, 318^{\circ}$ do CP), a suspensão (arts. $292^{\circ}, 316^{\circ}$, $318^{\circ} \mathrm{CP}$ ), a prisão correccional (arts. $290^{\circ}, 291^{\circ}, 294^{\circ}$ e $317^{\circ} \mathrm{CP}$ ) e a prisão maior (arts. $318^{\circ}$ e $319^{\circ}$ $\mathrm{CP}$ ). Pelas faltas constantes dos arts. $101^{\circ}, 102^{\circ}$ e $119^{\circ} \mathrm{CPC}$ poderiam ser aplicadas as penas de multa, suspensão e demissão dos escrivães ou secretários do juízo. Cfr. ainda os arts. $120^{\circ}, 139^{\circ}, 157^{\circ}$ e $173^{\circ}$ §único do CPC.

${ }^{78}$ Ratio idêntica é adoptada pelo art. $49^{\circ}$ Carta Constitucional francesa de 1814 e pela Constituição brasileira de 1824 (arts. $154^{\circ}-157^{\circ}$ ). Cfr. art. $22^{\circ}$ do Decreto de 12 de Novembro de 1881 e o art. $15^{\circ}$ do Decreto n. $^{\circ} 3$, de 29 de Março de 1890. 
ou erros de ofício revelassem negligência no cumprimento dos seus deveres. Neste caso a pena deveria ser imposta pelo Conselho Disciplinar da Magistratura Judicial aos juízes do continente e ilhas adjacentes e pelo Conselho Superior da Magistratura Judicial Ultramarina no caso dos juízes do ultramar ${ }^{79}$. Era aplicado ainda este tipo de pena aos delegados do procurador régio que haviam agido negligentemente em relação aos crimes de abuso de liberdade de imprensa ${ }^{80}$, cabendo neste caso a sua aplicação aos procuradores régios ${ }^{81}$ e aos empregados judiciais dos tribunais de justiça do continente e ilhas adjacentes e possessões ultramarinas que houvessem cometido faltas que sejam mencionadas e punidas pelas leis de processo ${ }^{82} .{ }^{83}$

A colocação no quadro poderia revestir, a natureza de pena disciplinar, ou não. No primeiro caso, deveria ser ordenada pelo Governo sempre que os juízes, dentro do prazo legal, não tomassem posse dos lugares para que haviam sido nomeados e não justificassem a falta nos 15 dias imediatos ${ }^{84}$; quando os juízes de direito, os desembargadores da Relação e os conselheiros do STJ exercessem a advocacia ou a

${ }^{79} \mathrm{Cfr}$. art. $13^{\circ}$ da Lei de 10 de Abril de 1849 , art. $1^{\circ}$ do Decreto n. ${ }^{\circ} 4$ de 15 de Setembro de 1892 e o art. $127^{\circ}$ do Regimento de 20 de Fevereiro de 1894.

${ }^{80} \mathrm{Cfr}$. art. $8^{\circ} \S \S 6$ e 7 do Decreto n. ${ }^{\circ} 1$ de 29 de Março de 1890 e dos arts. $80^{\circ} / 16$ e $127^{\circ} \S 4$ do Regimento de 20 de Fevereiro de 1894.

${ }^{81}$ A pena de suspensão quando aplicada ao magistrado do MP priva-o do exercício das suas funções, do vencimento total ou parcial, ou só do vencimento, conforme seja a sua determinação, importando sempre o desconto, para todos os efeitos, do tempo porque durar (art. $128^{\circ}$ do Decreto de 24 de Outubro de 1901).

${ }^{82}$ Cfr. art. $8^{\circ}$ da Lei de 11 de Agosto de 1860; art. $43^{\circ}$ do Decreto de 24 de Dezembro de 1885; art. $29^{\circ}$ do Decreto de 15 de Setembro de 1892; arts. $85^{\circ} / 19,124^{\circ}, 126^{\circ}$ do Regimento de 20 de Fevereiro de 1894 e os arts. $64^{\circ} \S 2,101^{\circ} \S \S 1$ e $2 ; 119^{\circ}, 120^{\circ} \S 2,139^{\circ} \S 2,182^{\circ}, 782^{\circ} \S$ único, $983^{\circ} \S 2,1006^{\circ} \S 2$ do CPC.

${ }^{83}$ Determinou o acórdão do STJ, de 20 de Outubro de 1893 que o juiz de direito só pode suspender os escrivães e mais oficiais de justiça nos casos e forma determinada na lei. Não pode por isso suspender qualquer empregado judicial que tendo sido convidado para o acompanhar na procissão de Corpus Christi e que cumpriu essa ordem, ainda que dela se tenha retirado sem ordem do mesmo magistrado. Concluía o mesmo acórdão que a retirada daquele empregado da procissão foi um acto pessoal e não de empregado subalterno em desconsideração ao seu superior. Por este motivo, não cometeu crime algum, nem faltou ao respeito e consideração devidos ao juiz por ter depois da procissão e no tribunal censurado a câmara pelo lugar designado para a corporação judicial. O juiz, intervindo nesta discussão, fê-lo como particular e como juiz, e se nos factos relatados houve desconsideração foi feita à pessoa e não ao magistrado.

${ }^{84} \mathrm{O}$ juiz ordinário não pode ser suspenso pela autoridade administrativa sob pena de abuso de poder e incompetência, in acórdão do STJ, de 15 de Novembro de 1838 . $V d$. ainda o art. $21^{\circ}$, do Regulamento de 13 de Dezembro de 1892 e os arts. 126\% $/ 2,129^{\circ}-133^{\circ}$ do Decreto de 24 de Outubro de 1901. Poderiam ainda ser aplicadas aos magistrados do Ministério Público, as penas especiais ou comuns constantes do Código Penal. Em relação aos oficiais de justiça, vd. Decreto de 29 de Novembro de 1901 e arts. $77^{\circ}$ e $80^{\circ}$ do Código Penal. Os empregados judiciais dos tribunais de justiça do continente e ilhas adjacentes poderiam igualmente ser suspensos do exercício das suas funções por acto do Governo e nas províncias ultramarinas por acto deste também ou pela autoridade que os nomeou (art. $124^{\circ}$ do Regimento de 20 de Fevereiro de 1894). 
profissão de comerciantes ou algum cargo público electivo, à excepção do pariato ou deputação ${ }^{85}$. Seria igualmente aplicada quando o magistrado no decurso da obtenção de licença, não regressasse ao lugar findo o respectivo prazo nem durante o período imediato de 30 dias consecutivos no continente e de 40 dias nas ilhas adjacentes ${ }^{86}$; ou, ainda, quando na sequência de promoção a classe superior de $1^{\mathrm{a}}$ instância ou à $2^{\mathrm{a}}$ instância, fosse ultrapassado o prazo que a lei concedia para a tomada de posse dos novos lugares ${ }^{87}$.

Este tipo de pena começava inicialmente por corresponder a uma suspensão por tempo indeterminado, vindo, mais tarde, a corresponder à integração de um lugar correspondente à sua categoria ${ }^{88}$; podendo ser imposta com ou sem perda de vencimentos. Assim, não teriam direito a perceber qualquer tipo de remuneração os juízes que dentro do prazo legal, não tivessem tomado posse dos lugares para que haviam sido nomeados e não tivessem justificado a falta nos 15 dias imediatos; bem como, os juízes de direito de primeira e de segunda instância que, no caso de transferência, sem motivo justificável, tivessem deixado de tomar posse dos novos lugares nos prazos legais. Para os demais casos já enunciados, cabia ao Governo determinar a privação ou não de vencimentos ${ }^{89}$.

A demissão, em regra, só poderia ter lugar em virtude de sentença judicial transitada em julgado (ex vi art. $122^{\circ}$ da Carta Constitucional, arts. $12^{\circ}, 37^{\circ}$ e $89^{\circ}$ da NRJ, art. $5^{\circ}$ da Lei de 16 de Abril de 1874, art. $12^{\circ}$ do Decreto de 29 de Julho de 1886). Poderia, desta forma, ser imposta na própria sentença ${ }^{90}$, ou constituir uma consequên-

${ }^{85} \mathrm{Cfr}$. art. $5^{\circ} \S 1$ da Lei de 18 de Agosto de 1848 e o art. $14^{\circ} \S$ único do Decreto n. ${ }^{\circ} 3$ de 29 de Março de 1890. Não tendo sido respeitado este prazo, deveria proceder-se a consulta afirmativa do Conselho de Estado, tratando-se de juízes do STJ, ou consulta afirmativa deste tribunal e audiência do presidente da Relação respectiva, tratando-se de outros juízes; seguida de audiência prévia do juiz arguido (Decreto n. ${ }^{\circ} 3$ de 29 de Março de 1890 , arts. $14^{\circ}$ e $15^{\circ}$ ).

${ }^{86} \mathrm{Cfr}$. art. $15^{\circ}$ §único Decreto n. ${ }^{\circ} 3$ de 29 de Março de 1890.

${ }^{87} \mathrm{Cfr}$. art. $5^{\circ}$ da Lei de 19 de Maio de 1864.

${ }^{88} \mathrm{Idem}$, art. $6^{\circ}$.

${ }^{89}$ Podia ocorrer ainda que a colocação no quadro apresentasse contornos bastante dilatados no tempo. Assim, é citado na proposta de lei apresentada por Artur Montenegro que em 1905 havia um juiz que estava no quadro há vinte e um anos, dois há dezassete anos, um há dezasseis, um há quinze, um há catorze, um há treze, três há doze, dois há onze, um há dez, um há nove, um há oito, um há sete, dez há seis, oito há cinco, seis há quatro, quatro há três; não atingindo nos restantes casos o período de três anos. Por este motivo, Artur Montenegro ter-se-ia visto impelido a apresentar no projecto em causa a proposta de que a permanência no quadro não deveria ultrapassar o período de três anos.

Como uma das primeiras medidas do Governo Provisório da República, os magistrados judiciais e do Ministério Público que se encontravam no quadro da magistratura sem exercício, mas com vencimento e que não tivessem sido declarados aptos para a efectividade de funções públicas seriam submetidos a um exame de sanidade, ex vi da Portaria de 20 de Outubro de 1910 (DG n..$^{\circ} 14$, de 21 de Outubro). ${ }^{90} \mathrm{Cfr}$. art. $5^{\circ}$ da Lei de 18 de Agosto de 1848 , arts. $129^{\circ} \S \S 1$ e 3 e $150^{\circ}$ do Regimento de 20 de Fevereiro de 1894.

Situação distinta ocorreria quando partisse de solicitação do juiz que por não reunir as condições mínimas para o exercício do cargo, quer fosse por motivos de avançada idade, ou incapacidade física; 
cia imediata e legal da sentença ${ }^{91}$. Seria aplicada pelo Governo em sede de processo disciplinar sempre que os juízes se recusassem a prestar juramento não se encontrando ainda no exercício do cargo (ex vi arts. $2^{\circ}$ e $3^{\circ}$ do Decreto de 5 de Março de 1856) ${ }^{92}$, ou no caso dos juízes municipais que exercessem a advocacia, a profissão de comerciante ou qualquer cargo público electivo, à excepção do pariato ou deputação, devendo, em todo o caso, a infracção ser previamente constatada pelo Presidente da respectiva Relação sendo indispensável a audiência prévia do arguido ${ }^{93}$.

A demissão, nos termos do art. $134^{\circ}$ do Decreto de 1901, poderia, ainda, ser aplicada nos casos de infracção manifesta da lei nos actos e decisões; a desobediência ou falta de acatamento às ordens dos superiores; a negligência ou omissão de que resultasse perigo ao interesse público ou aos serviços oficiais cometidos ao magistrado; o procedimento irregular que impossibilitasse o exercício de funções e a imposição, por três vezes, da pena de censura ou suspensão, em consequência da mesma falta ${ }^{94}$.

\section{As sindicâncias extraordinárias}

Como referimos anteriormente, enquanto as sindicâncias ordinárias decorrem como consequência do terminus do período da judicatura, as sindicâncias extraordinárias dependem da ocorrência de factos praticados, a qualquer momento, no exercício de funções ou fora deles, que pela sua importância e delicadeza impõem uma imediata investigação, a qual deverá partir de um despacho do Ministro dos Negócios Eclesiásticos e de Justiça. Este tipo de sindicância pode ocorrer ainda na sequência de uma transferência extraordinária, feita a requerimento do magistrado transferido, ou por conveniência de serviço.

A decisão de ordenar sindicâncias a requerimento do MP ou por iniciativa própria, desde que o Governo as requeresse, viria, mais tarde, na vigência do Decreto n. ${ }^{\circ} 3$, de 15 de Setembro de 1892, a ser conferida ao Conselho Disciplinar da Magistratura ${ }^{95}$.

Das sindicâncias extraordinárias dirá Martens Ferrão na proposta de lei apresentada em 1860 que são

solicitava a sua colocação no quadro. Neste caso não teria a natureza jurídica de pena não sendo, por conseguinte, necessária a consulta do Conselho de Estado nem do STJ.

Note-se que apenas nos casos de não-aceitação de uma nomeação poderia o acto de protelação do Governo face à permanência do magistrado naquela situação revestir a característica de uma pena, como forma de manifestação da vontade do Executivo.

${ }^{91}$ Cfr. arts. 71, 285, 287, 300, 301, 304, 316, 318, 326 do Código Penal.

${ }^{92}$ Cfr. Decreto de 5 de Março de 1856, Lei de 18 de Agosto de 1848, Decreto n. ${ }^{\circ} 4$ de 15 de Dezembro de 1894 e o art. $76^{\circ}$ e $83^{\circ}$ do Código Penal.

${ }^{93}$ Recorde-se que a situação de abandono da comarca conduzia à demissão.

${ }^{94} \mathrm{Cfr}$. Decreto n. ${ }^{\circ}$ 4, de 15 de Dezembro de 1894.

${ }^{95}$ No decreto da demissão deveriam ser especificados os motivos que a determinavam (art. $43^{\circ} \S 2$ do Decreto de 1901), devendo sempre ser realizada audiência prévia do arguido e a consulta do Supremo Conselho da Magistratura do Ministério Público (art. $45^{\circ} \S 1$ ). 
extraordinárias e excepcionais, tais como resultaram dessas leis ${ }^{96}$, e actualmente estão estabelecidas são um doloroso e ineficaz remédio de que sempre se hesitará em lançar mão. Doloroso porque ordenar uma sindicância extraordinária a um juiz é já lançar sobre os seus actos uma grave suspeita que reflecte sobre o seu carácter e o desautoriza; ineficaz, porque a grande limitação de poderes dos magistrados sindicantes, tornando a sindicância um processo meramente informatório, faz com que o público não confie no resultado de tais processos, e não lhes preste o auxilio das suas declarações, sem o qual esse mesmo resultado é inteiramente impossivel..$^{97}$

Em suma, a sindicância extraordinária poderia ser efectuada aos juízes de $1^{\mathrm{a}}$ e $2^{\mathrm{o}}$ instância ${ }^{98}$, assim como aos juízes eleitos.

Deste modo, sendo apresentada uma queixa contra um magistrado quer ao Ministério dos Negócios Eclesiásticos e de Justiça, quer ao Procurador Geral da Coroa, a mesma deveria, em teoria, ser remetida ao Conselho Disciplinar, o qual, apreciandoa, declararia, por acórdão, se deveria proceder-se à sindicância, ou não. Em caso afirmativo, era proposto ao Governo o nome do magistrado que ficaria incumbido do processo de averiguações. Aprovada a proposta pelo executivo, o magistrado sindicante seria notificado por decreto sendo-lhe indicada a data de início da sindicância, a qual decorreria na comarca onde, até então, o sindicado desempenhara funções.

Na prática, e sabendo que os conselhos disciplinares acabaram por não ser instituídos, tendo o Ministro dos Negócios Eclesiásticos e de Justiça decidido pela realização de uma sindicância extraordinária, notificava-se o agente da Procuradoria-Geral da Coroa a quem cabia proceder às devidas averiguações, o qual a partir de 1848 seria substituído pelo juiz substituto do juiz sindicado existente na comarca. Em termos do procedimento adoptado, há, sem dúvida, semelhanças entre os dois tipos de sindicância (ordinária e extraordinária). Ambos devem reflectir no termo de abertura as causas que conduziram à sua instauração, a que se seguiria, nos dois casos, a notificação e oitiva das testemunhas, devendo o sindicante ouvir não só as que pudessem ter conhecimento dos factos arguidos, mas também as de qualidade, ou seja, todos os indivíduos de reconhecida inteligência e probidade ${ }^{99}$.

\footnotetext{
${ }^{96} \mathrm{Cfr}$. art. $4^{\mathrm{o}}$ do mesmo diploma.

${ }^{97}$ Refere-se, neste caso, aos diplomas de 28 de Novembro de 1840, 1 de Agosto e 25 de Setembro de 1844, 18 de Agosto de 1848, 10 de Abril e 28 de Novembro de 1849.

${ }^{98}$ Já nas sindicâncias ordinárias, ...indo o magistrado encarregado dela armado de poderes suficientes para que o povo possa conhecer e apreciar a sua acção e os efeitos dela evita ambos estes gravíssimos inconvenientes (Martens Ferrão, ibidem).

${ }^{99}$ Cfr. Lei de 1 de Agosto de 1844 e a proposta de lei de 1861 (arts. 54 e seguintes). Aliás Martins de Carvalho, tendo como antecedente o celebérrimo caso da sindicância ao Tribunal da Relação do Porto, previa que durante o período da sindicância (ordinária ou extraordinária), sendo feita a todo o tribunal, não haveria lugar a sessões na respectiva relação, ainda que os magistrados não fossem obrigados a sair da cidade onde ela tivesse a sua sede (art. $56^{\circ}$ ), muito embora tratando-se de sindicância extraordinária
} 
Durante o período de instrução, o juiz sindicado deveria dirigir a peça contestatória ao juiz substituto do juiz sindicado e que desempenhava naquele momento, como referimos anteriormente, as funções de juiz sindicante.

Tendo chegado a uma conclusão, e não havendo um período determinado para a conclusão da diligência, contrariamente ao que sucedia com as sindicâncias ordinárias, era elaborado um relatório articulado e fundamentado que era remetido ao Presidente do respectivo Tribunal da Relação que, por sua vez, o encaminhava para o Ministro dos Negócios Eclesiásticos e de Justiça, seguindo, por fim, para a Procuradoria Geral da Coroa que decidiria se haveria ou não matéria para agir criminalmente.

Em caso afirmativo era seguido o trâmite normal deste tipo de processos. No caso da matéria apenas dizer respeito a aspectos disciplinares, caberia a correição aos órgãos judiciais como decorre dos arts. $5^{\circ}$ e seguintes da Lei de 10 de Abril de $1849^{100}$.

Esta é a realidade legislativa, face ao episódio judiciário que nos propomos apresentar.

\section{Outras situações}

\subsection{Erros de ofício e crimes}

Antes de analisarmos o caso específico ocorrido na comarca de Meda, impõe-se uma breve referência acerca do procedimento que era adoptado em sede da prática de erros de ofício e crimes, os quais não devem ser confundidos com as infracções cometidas pelos magistrados e funcionários judiciais. Assim, por erro de ofício devemos entender todo o acto que é cometido na matéria que se professa ou no cargo que se exerce, por engano, descuido, ignorância ou inaptidão ${ }^{101}$; ao passo que os segundos se encontram tipificados na lei penal, de que podemos citar os casos de suborno, peita, peculato e concussão ${ }^{102}$.

Para conhecer dos erros de ofício e crimes cometidos no exercício das suas funções ${ }^{103}$, pelos juízes eleitos, de paz, ordinários e subdelegados eram competentes os juízes de direito face aos actos praticados (arts. $85^{\circ}, 1.030^{\circ}$ e $\left.1.236^{\circ} \mathrm{NRJ}^{104}\right)$, ao passo

a alguns juízes, estes fossem obrigados a suspender as suas funções (art. $57^{\circ}$ ). $\mathrm{Vd}$. ainda os arts. $58^{\circ} \mathrm{e}$ seguintes da mesma proposta de 1861.

${ }^{100}$ Vide a este respeito o art. $25^{\circ}$ da proposta de Martins de Carvalho. Frise-se que, comparativamente aos textos anteriores, foi o primeiro a tratar detalhadamente a matéria das sindicâncias extraordinárias. ${ }^{101}$ A respeito da interposição do recurso de revista nos processos de sindicância, cfr. art. $52^{\circ}$ da proposta de lei de 1861.

${ }^{102} \mathrm{Vd}$. no mesmo sentido, nota $9 .{ }^{103}$ Vide a este respeito Ordenações Manuelinas (OM), livro III, título XXXIX e Ordenações Filipinas (OF), livro I, título C, livro III, título LXIII, os arts. $196^{\circ}$ e $198^{\circ}$ da Constituição de 1822 , arts. $123^{\circ}, 124^{\circ}, 130^{\circ}$ e $145^{\circ} \S \S 27$ e 28 da Carta Constitucional, arts. $15^{\circ}$ e 26 da Constituição de 1838 . $V d$. ainda os arts. $376^{\circ}-380^{\circ}, 382^{\circ}$ e $385^{\circ}$ da $3^{\text {a }}$ Parte da Reforma Judiciária; arts. $765^{\circ}, 772^{\circ}, 774^{\circ}-777^{\circ}-778^{\circ}, 782^{\circ}-785^{\circ}, 820^{\circ}-822^{\circ}, 1223^{\circ}$ e seguintes, $1.236^{\circ}-1.238^{\circ}$ NRJ e o Decreto de 29 de Julho de 1886 .

${ }^{104}$ No caso da prática de um crime, podia o Ministério Público bem como a parte ofendida ou ainda qualquer pessoa do povo, nos casos de suborno, peita, peculato e concussão dirigir a petição de querela 
que face aos crimes cometidos pelos juízes de direito de primeira e segunda instância, bem como membros do STJ e agentes do Ministério Público conheciam, respectivamente as Relações (art.43\%/1NRJ) e o STJ (arts. $20^{\circ} / 5$ e $\left.820^{\circ}-822^{\circ} \mathrm{NRJ}\right)^{105}$, nos termos do art. $374^{\circ}, 3^{\mathrm{a}}$ parte da RJ e $1240^{\circ} \mathrm{NRJ}^{106-107}$. Nos termos do art. $1026^{\circ} / 2$ e 3 da NRJ esta forma de conhecimento constituía ainda um caso de privilégio de foro.

\subsection{Correições realizadas a funcionários judiciais}

Se a residência ou sindicância tem como objecto uma investigação oficial a magistrados e funcionários judiciais ${ }^{108}$, podendo ser ordinária ou extraordinária, a correição consiste no exame que é feito pelos juízes aos livros e processos existentes nos cartórios dos juízos aos funcionários judiciais ${ }^{109}$ para verificar se estes cumpriram os seus deveres ${ }^{110}$ de modo a corrigir os abusos e erros encontrados ${ }^{111}$.

ao juiz competente (art. $375^{\circ} 3^{\mathrm{a}}$ parte da RJ e arts. $52^{\circ} / 3,771^{\circ}$ e $1237^{\circ} \mathrm{NRJ}$ ), devendo a mesma ser instruída com todos os documentos que lhe servirem de prova.Lopes Praça distingue peita ou suborno de concussão atendendo a que nesta a autoridade emprega a violência e naquele não. $\mathrm{O}$ crime de peita ou suborno dáse quando o juiz recebe um determinado valor para exercer as suas funções de modo justo ou injusto, legal ou ilegalmente, traficando com a autoridade. Em sentido rigoroso, peita é o nome dado à causa empregada para subornar a autoridade, suborno e corrupção designam o acto criminoso (Estudos sobre a Carta Constitucional de 1826 e o acto adicional de 1852, Coimbra, Livraria Portugueza e estrangeira, 1880, vol. I, p. 353). Nos termos dos arts. $197^{\circ}$ a $199^{\circ}$ da Constituição de 1822 tratando-se da parte interessada esta poderia proceder à acusação fundada em qualquer prevaricação a que na lei estivesse imposta alguma pena, contanto que aquela não consistisse em infracção à lei relativa à ordem de processo.

${ }^{105} \mathrm{Vd}$. Portaria do Ministério da Justiça de 16 de Outubro de 1845.

${ }^{106} \mathrm{Vd}$ art. $771^{\circ}$ e ss NRJ.

${ }^{107}$ Dispõe o art. $7^{\circ}$ do Decreto n. ${ }^{\circ} 60$ de 28 de Novembro de 1831 que ...os juizes que tiverem proferido sentenças, e os que tiverem preparado os processos, serão responsáveis às partes, ou a seus herdeiros, por todas as perdas e danos que com os mesmos processos e sentenças tiverem causado, e por qualquer descaminho de bens que tenham feito, ou consentido por fraude ou omissão. Além desta responsabilidade os juizes responderão criminalmente por toda a quebra das solenidades substanciais do processo, e por toda a decisão contra as regras mais óbvias da justiça, contra o direito expresso, ou contra a prova dos autos; e bem assim por quaisquer injúrias feitas aos réus em suas pessoas, ou boa fama, sem lei que as justifique, ou sem razão que as desculpe. Ainda sobre o abuso de poder por parte dos juízes, vide os Decretos n. ${ }^{\circ} 9$ e 10 de 13 de Abril de 1832.

${ }^{108}$ Era seguido o procedimento ordinário, não havendo qualquer intervenção do júri. Vide os arts. $14^{\circ}$, $196^{\circ}$ e $197^{\circ}$ da Constituição de 1822 e os arts. $123^{\circ}, 124^{\circ}$ e $145^{\circ} \$ 27$ da Carta Constitucional. A Constituição de 1838 é omissa quanto a esta matéria, dispondo apenas o art. $121^{\circ}$ que o rei poderá suspender os juízes de direito por queixas contra eles feitas, precedendo audiência dos mesmos juízes e ouvido o conselho de estado. Os papéis que lhes seriam concernentes, seriam remetidos à Relação do respectivo distrito para proceder na forma da lei. Ou seja, conjugar-se-ia esta disposição com o preceituado na NRJ encontrando-se a matéria consagrada legal e constitucionalmente.

${ }^{109} \mathrm{Vd}$. Portaria de 21 de Julho de 1883, relativamente ao modo como os juízes devem fazer correição aos cartórios dos tabeliães e ofícios de justiça, assim como o disposto nos arts. $85^{\circ} / 10$ e $548^{\circ}$ da NRJ conjugados com o art. $103^{\circ} \mathrm{CPC}$.

${ }^{110}$ Cfr. arts. $85^{\circ} / 10,110^{\circ}, 548^{\circ}$ e $564^{\circ}$ da NRJ, arts. $1^{\circ}$ a $6^{\circ}$ do Decreto de 9 de Abril de 1864 ; art. $92^{\circ}$ do Decreto de 30 de Junho de 1864 e a Portaria de 21 de Julho de 1883

${ }^{111}$ Acerca das suspeições relativas aos tabeliães do judicial, cfr. O.F., I. 80.4. 
Sempre que fossem encontradas irregularidades ${ }^{112}$ deveriam ser lançados provimentos nos próprios livros e processos ${ }^{113} \mathrm{e}$ aplicadas as penas disciplinares compreendidas na respectiva jurisdição; sendo os factos participados aos agentes do MP para que estes promovessem o respectivo procedimento criminal ${ }^{114}$.

Um pouco à semelhança do que outrora havia sido feito pelos corregedores do crime das cidades de Lisboa e Porto, o Decreto n. ${ }^{\circ}$ 5, de 29 de Março de 1890 atribuiria competência aos juízes criminais destas cidades para, periodicamente, procederem à correição, nos meses de Julho e Agosto e Novembro e Dezembro de cada ano, aos actos praticados por todos os funcionários judiciários daqueles distritos ${ }^{115}$.

As correições tanto poderiam ter lugar no continente como nos distritos judiciais das províncias ultramarinas, sendo este último caso regulado pelos Decretos de 1 de Outubro de $1856^{116}, 1$ de Dezembro de 1866, 29 de Novembro de $1876^{117}, 12$ de Agosto de $1880^{118}$ e 24 de Dezembro de 1885. Já o Decreto de 20 de Fevereiro de 1894 seria no entanto omisso quanto a este aspecto.

Por fim, o Decreto de 29 de Novembro de 1901 determinaria que no caso de faltas cometidas no exercício das funções, poderia o Presidente da Relação e o Procurador Régio, conforme as circunstâncias, admoestar os empregados, descontar-lhes os vencimentos, suspendê-los até trinta dias, comunicando a suspensão ao Ministério da Justiça e propor maior pena se o caso o exigisse.

\section{II. $O$ caso de Meda, 1850}

\section{José Januário Teixeira Leite de Castro: breves dados biográficos}

José Januário Teixeira Leite de Castro nasce a 3 de Abril de 1800, na freguesia de Santo Adrião de Sever, bispado do Porto ${ }^{119}$. É filho legítimo de Manuel António de

${ }^{112} \mathrm{Vd}$. O.F. I. 49 e 58 que estabelecia o dever de correição aos corregedores.

${ }^{113}$ Contra o abuso praticado por alguns escrivães em confiar os autos às partes, aos advogados ou aos procuradores sem recibo nem assinatura no competente protocolo, suscitando-se para este efeito a observância do Livro $1^{\circ}$, titulo $24,4 \S 22-26$ das O.F., aplicava-se o disposto no $§ 48$ do mesmo título, nos termos da Portaria de 30 de Abril de 1841. Da redacção imprecisa ou incompleta dos termos judiciais, assim como do retardamento na feitura dos mesmos actos, pagavam os tabeliães do judicial, para além das penas citadas na lei, as custas do retardamento, valores que o contador lhes descontaria dos salários. Se levassem mais do que lhes era devido seriam suspensos por seis meses (§16), ou perder mesmo o ofício (§18), incorrendo ainda nas penas do livro V, título 72 .

Vide ainda O.F. 5. 52.assim como o livro I, título 80, §§ 12, 13, 17, 19 e 20.

${ }^{114}$ Nos provimentos a correições dos funcionários judiciais, os juízes de Direito não podem proceder à regulação da execução das leis, nos termos das Portarias de 3 de Agosto de 1844 e 5 de Julho de 1852. ${ }^{115} \mathrm{Cfr}$. arts. $193^{\circ}$ e $213^{\circ}$ da RJ, $85^{\circ}, 110^{\circ}, 548^{\circ}, 564^{\circ} \mathrm{NRJ}$; arts. $1^{\circ}-6^{\circ}$ do Decreto de 9 de Abril de 1864; art. $92^{\circ}$ da tabela dos emolumentos de 30 de Junho de 1864; art. $97^{\circ}$ da Tabela de 13 de Maio de 1896. ${ }^{116} \mathrm{~A}$ mesma medida seria acolhida, posteriormente, pelos arts. $13^{\circ}$ e $90^{\circ}$ do Decreto de 29 de Novembro de 1901.

${ }^{117}$ In DG n. ${ }^{\circ} 245$.

${ }^{118}$ In $\mathrm{DG} n .^{\circ} 272$.

${ }^{119}$ In DG n. ${ }^{\circ} 183$. 
Castro e de sua mulher Ana da Trindade, do lugar de Urbal, freguesia de Santo Adrião de Sever. É neto paterno de António Francisco e de Quitéria Maria da Fonseca, da freguesia de Santa Maria dos Anjos de Guivães e neto materno de José Teixeira Alves e de Maria Josefa, do lugar de Mofamedes e freguesia do mesmo nome ${ }^{120}$.

A análise dos registos académicos da Universidade de Coimbra, revela que no ano lectivo de 1818/19 está inscrito na aula de Retórica do Real Colégio das Artes ${ }^{121}$, encontrando-se no ano seguinte matriculado no $1^{\circ}$ ano jurídico da Faculdade de Teologia $^{122}$. A frequência académica segue de modo regular ou continuado até ao ano de 1822/23, período em que está registado como aluno do $4^{\circ}$ ano do Curso de Leis. Após um ano de interrupção, terminaria, em 1826, o curso de Leis da Universidade de Coimbra.

Na sequência dos acontecimentos políticos vintistas, o supracitado bacharel dá entrada na cadeia da Relação, em 26 de Agosto de 1828, na sequência da prisão declarada em Vianna. Mais tarde, em 27 de Abril de 1831, sendo residente em Santa Marta, são-lhe assignados cinco dias para dizer de facto, e de Direito sobre outra ordem de detenção. Em 17 de Agosto do mesmo ano é condemnado em 2 annos de reclusão na Praça de Campo Maior e em $100 \$$ réis para as despesas da Alçada. Em 21 de Outubro forão-lhe despresados os Embargos com que se oppoz à condemnação; por isso em 11 de Maio de 1832 foi remettido, por terra, para Lisboa, a fim de hir para o seu destino ${ }^{123}$.

Leite de Castro é um magistrado da nova magistratura ${ }^{124}$ cuja carreira inicia na comarca de Portalegre em 1 de Maio de $1834^{125}$. Subsequentemente, desempenhará

${ }^{120} \mathrm{Vd}$. registo de baptismo a fls. 38, datado de 15 e Abril do mesmo ano daquela freguesia e bispado, apud. certidão integrante do processo de leitura de bacharéis (in IANTT, 1827, maço 80/5).

${ }^{121}$ Cfr. registo de baptismo de 15 de Abril de 1800, a fls. 38 do processo de leitura de bacharéis do ano de 1827, maço 80/5 (in IANTT). No mesmo processo aparece, todavia, uma ligeira contradição face à data de nascimento do referido bacharel, ou seja, enquanto o documento firmado por D. José Joaquim Carneiro de Carvalho, comendador da Ordem de Cristo e desembargador da Casa da Suplicação, servindo de corregedor da corte, que tem por objectivo justificar a frequência e presença nas do citado bacharel nas audiências, confirma a idade de vinte e sete anos à data de 7 de Março de 1827; o documento de D. José de Carvalho Martens da Silva Ferrão, fidalgo da Casa de Sua Majestade, desembargador de agravos da Casa da Suplicação, corregedor do cível da corte de $1^{a}$ vara, menciona que o mesmo bacharel tem apenas 25 anos em 6 de Março de 1827.

${ }^{122}$ In Relação e Indice Alphabetico dos estudantes matriculados na Universidade de Coimbra no anno lectivo de 1818/19, suas naturalidades, filiações e moradas, Coimbra, Imprensa da Universidade, 1818, p. 62.

${ }^{123}$ Nos anos de 1819/20,1820/21,1821/22, 1822/23 e 1823/24 matricular-se-á, respectivamente no $2^{\circ}$ ano jurídico da Faculdade de Teologia e no $3^{\circ}$ e $4^{\circ}$ anos da Faculdade de Leis, conforme registo de págs. 7, 13, 18, 21 e 24 da Relação e Indice Alphabetico dos estudantes matriculados na Universidade de Coimbra... para aqueles anos. No ano de 1823/24 não se matriculará e só em 1824/25 frequentará o $5^{\circ}$ ano de Leis (cfr. p. 26) concluindo então o bacharelato em Leis.

${ }^{124}$ In Vellozo, Pedro da Fonseca Serrão, Collecção de Listas que contem os nomes das pessoas, que ficarão pronunciadas nas devassas, e summarios, a que mandou proceder o Governo usurpador depois da heroica contra-revolução, que arrebentou na mui nobre, e leal Cidade do Porto em 16 de Maio, de 
as funções de magistrado nas comarcas de S. João da Pesqueira (1835) ${ }^{126}$, Peso da Régua (1836-1837127), Chaves (1837) ${ }^{128}$, Faro (1840-1844) ${ }^{129}$, Aldeia Galega do Ribatejo $^{130}\left(1845^{131}\right)$, Vila Pouca d'Aguiar $(1846)^{132}$, Meda (1848-1854) $)^{133}$, Vale Paços

1828, nas quaes se faz menção do destino, que a Alçada, creada pelo mesmo Governo para as julgar, deu a cada uma dellas, Porto, Typ. de Viuva Alvares Ribeiro \& Filho, 1833, p. 73.

${ }^{125}$ Por nova magistratura entendemos o colectivo de juízes que iniciaram funções após a entrada em vigor da Constituição de 1822 e da legislação das décadas de trinta e quarenta que veio regular o novo estatuto da magistratura, por oposição aos juízes de fora do período absolutista.

${ }^{126}$ Nesta data toma posse como juiz de fora de Portalegre onde serve até final de Agosto de 1835.

Um traslado do livro das actas das sessões da Câmara Municipal de Portalegre de 1834 refere que Leite Castro tomou posse nesta data tendo-se apresentado naquela comarca a 6 de Agosto de 1834, altura em que apresenta uma licença que lhe é concedida por um mês. No entanto, não há qualquer documento ou referência que prove o regresso àquela comarca.

${ }^{127}$ Segundo informação constante de um documento datado de 20 de Dezembro de 1864, é despachado, em 1835 para a comarca de S. João da Pesqueira onde serve como juiz de direito, tendo tomado posse em 14 de Setembro do mesmo ano, segundo um documento da Procuradoria-Geral da Coroa do Porto. Dada a inexistência, na altura, de livros de posse naquela comarca, existe uma nota do escrivão do $3^{\circ}$ oficio do juízo de direito que dá conhecimento de um protocolo das audiências de 20 de Fevereiro de 1835 a 26 de Agosto de 1841, a cujas fls. 14 consta que Leite Castro teria tido marcada a sua primeira audiência ordinária para a data de 14 de Setembro de 1835. No entanto, em virtude da mesma ter sido adiada não consta que tenha presidido a nenhuma.

${ }^{128}$ As datas de 3 de Novembro de 1836 e 11 de Maio de 1837 dizem respeito à primeira e última audiência a que Leite Castro preside em Peso da Régua.

${ }^{129}$ De acordo com a informação prestada pela Câmara de Chaves, há um auto desta data que relata que Leite Castro se apresentou e tomou posse naquela comarca. Um segundo documento refere que Leite Castro exerceu funções em Chaves até 1 de Maio de 1840 tendo completado o triénio, segundo documento de 16 de Maio de 1840. Em 6 de Abril de 1840 pede a transferência para a comarca de Faro, mas como estava ainda em Chaves teve 30 dias para se apresentar, o que veio a ocorrer em Junho depois de ter prestado juramento a 17/Junho e tomado posse a 15/Julho devido à resistência que o juiz Jaime Samora fez à sua tomada de posse. Durante o período em que exercerá funções em Faro será removido por motivos políticos para Mafra (em 12 de Fevereiro de 1844) e desta localidade para Belas onde esteve até depois da capitulação da força d'Almeida. Em 14 de Abril de 1845, Leite Castro participa à Presidência da Relação de Lisboa que tinha saído de Mafra e chegado a Belas em 13 de Abril de 1845 não havendo qualquer indicação do seu regresso a Faro.

${ }^{130}$ De 20 de Julho de 1840 a 8 de Fevereiro de 1844 permanecerá em Faro. No livro de juramentos do Tribunal da Relação dos Açores, a fls. 45 consta o termo assinado pelo procurador de Leite Castro (Manuel José Ribeiro) com data de 27 de Junho de 1844, nos termos do qual toma posse do lugar de juiz de direito, ex vi do despacho de transferência de 8 de Maio de 1844 vindo da comarca de Faro (cfr. decreto da mesma data).

${ }^{131}$ Em 24 de Dezembro de 1844, é transferido para esta comarca. Por decreto de 8 de Maio de 1844, é transferido para S. Jorge e presta juramento a 27 de Julho, por meio de um representante. A sua transferência é suspensa e é conduzido para Aldeia Galega no Ribatejo, por decreto de 24 de Dezembro de 1844, onde tomaria posse em 7 de Fevereiro de 1845.

Em referência à Portaria do MNEJ de 30 de Janeiro de 1845, foi determinado que o MP procedesse contra Leite Castro, o qual é transferido para Aldeia Galega do Ribatejo pela prática escandalosa do crime ocorrido em 22 de Janeiro de 1845 contra o governador civil de Faro, Manuel Henriques de Azevedo Aboim. ${ }^{132}$ Leite Castro toma posse em 7 de Fevereiro de 1845 em Aldeia Galega tendo ali realizado a sua última audiência em 31 de Maio de 1845 (apud documento datado de 6 de Junho de 1864). 
$(1854)^{134}$, Lamego $(1855)^{135} \mathrm{e}$ Viseu (1858) ${ }^{136}$. Mais tarde na qualidade de juiz desembargador integrará os quadros das Relações de Ponta Delgada (1858) ${ }^{137}$, Porto $(1861)^{138}$ e Lisboa (1865).

Muito embora a sua progressão na carreira judiciária pareça decorrer, aparentemente, sem quaisquer problemas, tal não sucedeu. Não haverá qualquer exagero se dissermos que o seu percurso como magistrado foi tenebroso visto ter sido alvo de várias sindicâncias extraordinárias tendo, inclusive, sido indiciado em alguns processoscrime (de natureza política e criminal). De igual modo, o seu nome estará associado a algumas insurreições contrárias ao governo de D. Miguel (1828 e 1831) e às sublevações de Almeida (1844) e do Porto (1847), o que lhe valerá alguns sobressaltos.

O seu percurso como juiz de direito apresenta três sindicâncias extraordinárias de particular delicadeza e gravidade, ainda que o seu cursus honorum não tenha, ao final, sido ferido. Tratam-se dos episódios ocorridos em Faro (1845), Vila Pouca de Aguiar (1847) e Meda (1849).

Intercalado com algumas participações políticas mais revoltosas, em 1845 seria acusado da prática do crime de injúrias de que tinham sido vítimas o governador civil de Faro, Manuel Henriques de Azevedo Aboim, e esposa. O caso é conduzido até à Relação de Lisboa, sendo depois interposto recurso de revista, vindo, ao final, o sobredito magistrado a ser ilibado, nos termos da decisão lavrada pelo Tribunal da Relação de Lisboa (1850).

Como consequência dos processos de sindicância extraordinária que the são dirigidos, vários serão os períodos em que é forçado a interromper funções ${ }^{139} \mathrm{e}$ que, mais

\footnotetext{
${ }^{133}$ Toma posse nesta data na comarca de Vila Nova d'Aguiar por meio do seu procurador, José Bernardino de Sousa Alvares de Aguiar., em 29 de Janeiro de 1846, na sequência do decreto de transferência de 26 de Novembro de 1845 (cfr. fls. 33 do livro de posses). Importa frisar que a sua transferência decorre da concessão da amnistia concedida ex vi do Decreto de 28 de Abril de 1847, in DG n. ${ }^{\circ} 135$.A data da sua última audiência realizada esta comarca de Vila Nova d'Aguiar data de 20 de Novembro de 1848.

$V d$ ainda o doc. de 13 de Julho de 1847 in IANT, MNEJ, maço 363/5, doc. n. ${ }^{2} 2$.

${ }^{134}$ De acordo com o livro de protocolos de 1848, conclui-se que a primeira audiência de Leite de Castro, em Meda, tem lugar a 18 de Dezembro de 1848 e a última a 3 de Fevereiro de 1854 . A 18 de Janeiro de 1854, Leite de Castro seria transferido da comarca de Meda para Valpaços por ter completado o quadriénio, cfe. despacho da mesma data publicado no DG n. ${ }^{\circ}$ 18, de 21 de Janeiro de 1854.

${ }^{135}$ Data da tomada de posse em Valpaços, de acordo com o livro $1^{\circ}$ dos autos de posse e juramentos.

De acordo com um segundo documento da mesma comarca, datado de 26 de Maio de 1864, o livro de protocolo de lembranças, a fls. 130, indica que a última audiência de Leite Castro ocorreu a 16 de Julho de 1855.

${ }^{136}$ É transferido a 22 de Agosto de 1855, tendo sido transferido por Decreto de 20 de Maio de 1855 e tomado posse em 1 de Novembro de 1855.

${ }^{137}$ Leite de Castro foi despachado para esta comarca por Decreto de 16 de Junho de 1858 (cfr. 16v. do Livro de posses e juramentos da comarca de Viseu)

${ }^{138}$ Por Decreto de 25 de Agosto de 1858, Leite de Castro é transferido para a Relação de Ponta Delgada, tendo tomado posse nesta comarca em 18 de Dezembro de 1858 (cfr. doc. datado de 10 de Agosto de 1864). ${ }^{139}$ A sua transferência para a Relação do Porto consta do Decreto de 12 de Dezembro de 1861 para ocupar a vaga deixada por Joaquim Pedro Júdice. Em 25 de Janeiro de 1861, jura e toma posse como
} 
tarde, teriam implicações na contagem do período de exercício de funções para efeitos de aposentação ${ }^{140} \mathrm{e}$ da concessão do terço no vencimento atribuído por antiguidade. Ainda que em alguns casos a suspensão do exercício de funções tenha sido decretada judicialmente na sequência de processos de averiguações, estas não constituirão o alvo da nossa atenção. O objecto do nosso estudo recairá, outrossim sobre a investigação que foi exercida aos actos praticados por Leite de Castro na qualidade de juiz de direito da comarca de Meda, em 1850, onde foi acusado do exercício de abuso de poder.

Não obstante os episódios enunciados que poderiam ter tido graves implicações disciplinares, Leite Castro receberá apenas como pena a transferência extraordinária, como sucede em Fevereiro de 1844 quando é enviado para Mafra ${ }^{141}$, ou, ainda, quando é enviado para a ilha de S. Jorge em Maio do mesmo ano e, logo em seguida, em Dezembro, para Aldeia Galega no Ribatejo. Em 1847, seria ainda transferido extraordinariamente da comarca de Vila Pouca de Aguiar para Meda, em virtude de algumas desavenças ocorridas naquela comarca, tornando-se a sua transferência do interesse público, como o definiria a decisão do Supremo Tribunal de Justiça datada de 13 de Dezembro de $1847^{142}$.

O seu falecimento viria a ocorrer em 29 de Agosto de $1870^{143}$, em Lisboa, na qualidade de juiz desembargador do Tribunal da Relação de Lisboa ${ }^{144}$.

\section{A sindicância judicial extraordinária ${ }^{145}$ \\ 2.1. A denúncia e o processo de averiguações}

O processo que está na base do presente trabalho é semelhante a muitos outros que com ele povoaram o cenário judiciário de oitocentos. Quezílias pessoais e dissi-

juiz da Relação do Porto vencendo o respectivo ordenado até 15 de Março de 1865 altura em que é transferido para a Relação de Lisboa.

${ }^{140}$ Tal vem a ocorrer em 14 de Setembro de 1835, de 1 de Maio de 1840 a 20 de Julho de 1840 , de 8 de Fevereiro de 1844 a 7 de Fevereiro de 1845, de 31 de Maio de 1845 a 29 de Janeiro de 1846 e de 16 de Julho de 1855 a 1 de Novembro de 1855.

${ }^{141} \mathrm{Cfr}$. docs. in IANTT, MNEJ, maço 542/5.

${ }^{142}$ Cfr. Portaria de 8 de Março de 1844 que manda consultar o STJ, em vista do disposto na Lei de 1 de Julho de 1843, tendo sido lavrada a resposta à consulta, em 16 de Abril do mesmo ano, a qual seria firmada pelos conselheiros Paiva Pereira, Visconde de Laborim, Camelo, Leitão, Cardoso, Ribeiro Saraiva, Cabral, Osório, Abreu Castelo Branco e Vellez Caldeira que votaria vencido.

${ }^{143} \mathrm{Vd}$. IANTT, MNEJ, maço 363/5, fls. 31 e 32.

${ }^{144}$ Cfr. IANTT, ADL, PGC, Tribunal da Relação de Lisboa, TR 36, maço 477/6. Vd ainda do mesmo maço os n. ${ }^{\text {os }} 2-5$ e maço $476 / 60$.

${ }^{145}$ Importa salientar que em 1865 e ao abrigo da Lei de 17 de Agosto de 1853, solicita o percebimento de mais $1 / 3$ do seu ordenado, invocando para tanto mais de trinta anos de serviço, muito embora as sucessivas interrupções verificadas ao longo da sua carreira judiciária não o tenham permitido em virtude das injustificações ocorridas. De igual modo, se o tempo de serviço que alegava deter, lhe permitia, igualmente, a solicitação da aposentação, nunca veio a fazê-lo. 
dências políticas foram muitos dos motivos que estiveram na base de participações que eram remetidas às autoridades locais, ao tribunal da Relação do distrito em questão, ou mesmo, ao ministro dos Negócios Eclesiásticos e de Justiça.

O caso sub judice tem início numa denúncia anónima ${ }^{146} \mathrm{e}$ não datada (doc.1), remetida à autoridade administrativa local, a qual revela um conjunto de acusações a respeito de José Januário Teixeira Leite de Castro, juiz de direito da comarca de Meda. No mesmo documento é mencionado o facto de anteriormente se ter comunicado ao Ministério dos Negócios Eclesiásticos e de Justiça alguns dos excessos, arbitrariedades e despotismos cometidos pelo mesmo magistrado, ainda que, até àquele momento não tivessem sido tomadas quaisquer medidas. Por este motivo, é pedida a transferência do denunciado, caso não fosse possível decretar a sua demissão.

Tendo recebido a citada denúncia, o administrador do concelho da mesma localidade, Miguel António de Figueiredo Vasconcelos, decide enviar uma representação ao Ministro dos Negócios do Reino, em 10 de Março de 1850 (doc. 2), onde relata que o mencionado magistrado teria impedido o cumprimento de um auto de penhora dos bens deixados pelo padre Jerónimo de Gamboa Pinto e Sousa, o qual tinha por objectivo saldar uma divida à Fazenda, em especial o pagamento das côngruas de que aquele era devedor. $\mathrm{O}$ mesmo documento é ainda bastante claro no que diz respeito ao carácter conflituoso de Leite de Castro ${ }^{147}$, informando-se, então, que aquele tinha ocasionado já vários confrontos com os funcionários do poder local a quem tinha dado ordem de prisão, sem prévia licença do governo, o que violava notoriamente a legislação em vigor.

Como consequência da documentação apresentada, o administrador do concelho de Figueira de Castelo Rodrigo, Francisco da Guerra Bordalo da Fonseca recebe uma ordem do governador civil do distrito da Guarda (de 27 de Março de 1850) para que proceda às devidas diligências, tendo o processo de averiguações tido início em 19 de Abril de 1850 (doc. 3) ${ }^{148}$. O termo de assentada é lavrado em 23 de Abril ${ }^{149}$ e, em

\footnotetext{
${ }^{146}$ In IANTT, MNEJ, maços n. ${ }^{\circ}$ s 556/7 e 542/5.

${ }^{147}$ Mais tarde, numa das respostas apresentadas por Leite Castro, o mesmo viria a admitir que desconfiava ter sido Miguel Jerónimo, o seu juiz substituto, o autor da denúncia em questão, vd. doc. datado de 30 de Maio de 1850, in apêndice documental.

${ }^{148}$ Segundo descrição de algumas pessoas capazes d'aquella comarca (...) aquelle juiz he d'um carácter guerrilheiro, impróprio d'um magistrado judicial e exaltado setembrista. $\mathrm{O}$ mesmo magistrado é definido, ainda, como inimigo declarado do governo, o qual procura por todos os meios hostilizar (...) e tornar nula a acção administrativa processando os seus empregados por factos praticados no exercício de suas funç̧ões. Com data de 6 de Maio de 1850 é apensado um documento que noticia que Leite Castro teria ameaçado algumas testemunhas tendo o juiz substituto parado com as diligências e requisitado ao governador civil uma escolta de 12 soldados de infantaria.

${ }^{149}$ Nestes autos é apresentada a matéria relativa ao sucedido por altura da execução do mandato de penhora efectuado pelo administrador do concelho de Meda aos bens do padre Jerónimo de Gamboa Pinto e Sousa e que teria sido dificultada por intervenção de Leite Castro. Para o autor da presente exposição, o juiz de direito, ora arguido, teria divulgado que havia de culpar tanto o juiz como o escrivão da administração e oficial de diligências por decidirem fazer a penhora (in IANTT, MNEJ, maço 556/7, fls. 2-2v).
} 
3 de Maio do mesmo mês, estando os autos conclusos, a documentação é remetida ao Governador Civil da Guarda, João Crisóstomo Freire Correia.

O processo de averiguações viria a concluir pela acusação de Leite de Castro na prática de abuso de poder. A acusação enumerava uma série de incidentes relacionados com as testemunhas chamadas a depor em diversos processos e os jurados que tinham sido eleitos e integrado as audiências gerais do segundo semestre de 1849 . Desta feita, Leite de Castro teria insultado e decidido encarcerar na loja da casa da câmara da vila de Meda por não haver cadeia as testemunhas cujos depoimentos eram contrários à sua vontade, mandado consignar nos respectivos termos alegações que aquelas não haviam proferido; tendo, por fim, atormentado e ameaçado as mesmas testemunhas, acusando-as de resistência e exigindo, a cada uma, para efeito de livramento o pagamento abusivo e ilegal de 240 e 720 réis $^{150}$, a cada uma. Situação idêntica teria ocorrido com outra testemunha, Manoel d'Almeida, nas audiências gerais do segundo semestre de 1849, o qual também teria sido insultado, encarcerado e obrigado a pagar, indevidamente, pelo seu livramento. São citados outros casos relativos a processos-crime, onde é mencionado, mais uma vez, o pagamento indevido de emolumentos judiciais. Para efeitos de livramento, frise-se que o mesmo magistrado não só não atendia ao grau de pobreza dos réus, como se verificara no caso dos réus de Casteição, em que o mais abonado tivera de custear as custas relativas demais, mas também levava, nas demais circunstâncias, emolumentos e salários excessivos. Situação igualmente insólita ocorreria com os jurados que compunham as audiências gerais do segundo semestre de 1849, os quais, em virtude de não terem decido conforme a vontade do magistrado, foram destituídos e, subsequentemente, substituídos por um segundo júri.

A prática de injúrias não se resumia aos casos já enunciados, uma vez que o mesmo magistrado teria distratado uma menina honesta e bem comportada e insultado a mãe e demais pessoas que acompanhavam dizendo as atirava do palanquim abaixo. Ainda no mesmo ano (1849), Leite de Castro teria mandado encarcerar na cadeia a 20 léguas do Carvalhal, uma órfã que queria casar contra a vontade do tutor, tendo-a desgraçado em virtude de uma amizade ilícita que ali estabeleceu.

\footnotetext{
${ }^{150} \mathrm{O}$ primeiro termo de depoimentos é lavrado no lugar de Outeiro dos Gatos (fls. 7-16v.). Prestaram depoimento, na qualidade de testemunhas, Joaquim Nicolau de Sousa, casado e proprietário, 30 anos (fls. 7-8) Manuel António de Almeida Júnior, solteiro, fillho de Manuel d'Almeida, lavrador de Casteição (fls. 8-9); Maria Dorothêa, casada com João António, jornaleiro, da Casteição (fls. 9-10); Teresa de Jesus, casada com António Palhais jornaleiro de Casteição (fls. 10-11); Leocádea Antónia, solteira, filha de Manuel de Aguiar, jornaleiro de Casteição (fls. 11-12); Josefa de Jesus, solteira, filha de José Ramos de Casteição (fls. 12-12v); João António de Sousa, pároco de Casteição (fls. 12v-14v); Sebastião Machado Coelho de Azevedo, casado, proprietário dos Chãos (fls. 14v-15v); e Manuel d'Almeida Júnior, casado, lavrador de Casteição, 50 anos (fls. 16-16v). As testemunhas confirmam as acusações feitas, nomeadamente a prática do crime de injúrias invocando os homens que Leite Castro lhes teria chamado marotos e bregeiros, as prisões indevidas, inclusive da órfã do Carvalhal e do regedor de Poço do Canto e o pagamento ao oficial de diligências, José Maria Alves, da quantia de 720 réis por pessoa, em sede de livramento.
} 
O leque de práticas irregulares é sobejamente vasto. Terminava a mesma peça acusatória por referir o episódio verificado com o regedor de Poço do Canto. Face ao exposto, Leite de Castro, e em total violação do disposto na Circular do Ministério do Reino, de 19 de Março de 1843, teria, em primeiro lugar dado ordem de prisão pelo período de trinta dias ao regedor de Poço do Canto em virtude da ocorrência de actos praticados no exercício do seu cargo; e, em segundo lugar, anulado os inventários que o juiz de direito substituto fizera tramitar enquanto esteve vago o lugar de juiz proprietário, dizendo que o juiz anterior era incompetente, apenas com o fim de extorquir os emolumentos dos segundos inventários, desrespeitando assim o disposto no titulo 11, art. $4^{\circ}$ da Nova Tabela de Emolumentos.

Na posse de toda esta informação, o Ministro do Reino, António Bernardo da Costa Cabral $^{151}$, manda expedir um ofício, datado de 8 de Maio de 1850, dirigido ao

${ }^{151}$ A situação não é inédita, se recordarmos a narrativa constante de um dos parágrafos do ofício de 12 de Fevereiro de 1844 do procurador-geral da Coroa. Assim, ...são de natureza mui gravee escandalosas imputações feitas ao juiz de direito da comarca de Faro, José Januário Teixeira Leite de Castro; e posto que algumas sejão vagas e destituidas de prova, com as parcilalidades e despotismos na administração da justiça, as annuencias a solicitações para a torcer outras todavia tem já grande começo de provana inquirição de testemunhas, a que se procedeo admninistrativamente, e por estas se lhes deve fazer effectiva a responsabilidade nos termos legaes. A ordenação do livro $3^{\circ}$, tit, 19, $\$ 14$, expressamente proíbe aos juizes que uzem de palavras injuriosas com as partes que perante elles requerem, ordenando neste cazo aos superiores que procedam contra elles segundo as natureza dos actos; e da inquirição adjunta consta exuberantemente que o juiz de direito arguido, desconhecendo a dignidade do cargo que exerce, abusa delle, maltrata com termos e palavras afrontosas as partes que lhe demandão justiçae que em vez desta encontrão os ultrages e offensas. Não pára aqui o abuso deste juiz ;mostra a inquirição adjunta os frequentes e repetidos assaltos por elle feitos à pudicícia das partes de sexo feminino, que perante elle requerem, as suas instancias para os mover e obrigar á satisfação de seus libidinosos desejos, actos que desacreditãoe infamão o funcionário público, e que constituem o crime que a Ord. Do L. 5, tit. 18 $\$ 2$ manda punir com a pensa de direito, que he a de degredo, ainda quando não he accompanhado de circunstancia agravante de ser commettido no exercício do cargo público, com abuso da autoridade delle. A ord. Do L. 5 tit 20 impoem a pena da perda de officio, e de um anno de degredo para África ao juiz que tiver ajuntamento carnal com qualquer mulher que perante elle litigue, e este crime he attribuido ao juiz arguido no summario adjunto, onde algumas testemunhas depõem que elle o commetera em Março de 1841 na villa de Loulé, com uma presa do seu juízo e que poucos dias depois condenou em degredo perpétuo pelo crime de homicídio de que era accusada. Finalmente as testemunhas $N .{ }^{\circ} 13,16$ e 20, depondo de facto próprio, emputão ao juiz, prisões arbitrarias para satisfação de paixões particulares e todos estes factops são tão graves e escandalosos, deprimem tanto a Aucthoridade Pública, que sem grandissimo detrimento della não podem ficar impunes quando se mostremverdadeiros, nem o Governo de Vossa nagestade, sem quebra do seu decoro e dignidade, pode deixar de mandar proceder pelos meios legaes contra este juiz sobre o qual pesão tão graves imputações acompanhadas já de forte começo de prova. Nestes termos he meu parecer, que o summario de testemunhas adjunto deve ser enviado ao Ministério da Justiça, a fim de que sendo previamente ouvido o juiz sobre os crimes que lhe são imputados, se proceda á sua suspensão, ou ainda sem previa suspensão, se mande já instaurar o processo na conformidade da lei, parecendo-me que este segundo meio deve com preferência ser adoptado por que um dos crimes está próximo de prescrever, se com brevidade não for prestada a querella.

Está conforme $=$ Secretaria d'Estado dos Negócios Ecclesiasticos e de Justiça em 24 de Fevereiro de 1844 (in Iantt, MNEJ, maço 542/5). 
Ministro dos Negócios Eclesiásticos e de Justiça, Félix Pereira de Magalhães ${ }^{152}$, dando-lhe a conhecer as conclusões apuradas no processo de averiguações (doc. 4).

Face ao exposto, seriam tomadas, de imediato, as devidas medidas pelo Presidente do Tribunal da Relação do Porto, Bernardo José Vieira da Mota ${ }^{153}$, sendo determinada a realização de uma sindicância extraordinária a José Januário Teixeira Leite de Castro.

\subsection{A sindicância ou residência extraordinária}

Em Maio de 1850 é instaurado, em Meda, o processo de sindicância extraordinária a Leite de Castro ${ }^{154}$, no âmbito do qual são ouvidas várias testemunhas pelo juiz substituto Miguel Jerónimo Pinto Ferreira ${ }^{155}$, nas datas de 11, 14 e 17 daquele mesmo mês ${ }^{156}$, e em $14^{157}$ e 17 de Junho ${ }^{158}$.

152 António Bernardo da Costa CABRAL, $1^{\circ}$ Conde e $1^{\circ}$ Marquês de Tomar (1803-1889). Filho de António Bernardo da Silva Cabral e de Francisca Vitória Rebelo da Costa Corte Real. Bacharel em Direito, advogado e juiz de fora, membro do Supremo Tribunal de Guerra, auditor geral do exército durante o governo de D. Pedro. Desempenhou as funções de Procurador Régio na Relação do Porto (1832-34), juiz da Relação dos Açores (1834), deputado, Ministro dos Negócios Eclesiásticos de Justiça, Conselheiro de Estado, Par do Reino e embaixador de Portugal em Madrid após o episódio político conhecido por "Maria da Fonte".

${ }^{153}$ Félix Pereira de MAGALHÃES, nasce em Chaves, em 1794 e falece em 1878. Bacharel em Leis (1821). Eleito senador (1838-1842) e deputado (1842-1845), seria ainda nomeado par do Reino (18451870). Durante o período de 1849-1851 exerceria as funções de ministro dos Negócios Eclesiásticos e da Justiça.

${ }^{154}$ Bernardo José Vieira da MOTA (1784-?), filho legítimo do Capitão Bernardo José Vieira da Mota e de sua mulher D. Maria Joana, natural da freguesia de S. Romão de Paredes, concelho de Benviver, comarca do Porto (in IANTT, Leitura de Bacharéis, 1810, maço 12, letra B, n. ${ }^{\circ}$ 3). Bacharel em Leis pela Universidade de Coimbra (1807), viria a realizar o exame de leitura junto do Desembargo do Paço em 1810. Vd. ainda a Relação dos estudantes matriculados na Univerfidade de Coimbra no Anno Lectivo de 1806-1807, p. 21.

${ }^{155}$ In Iantt, MNEJ, maço 556/7.

${ }^{156}$ Miguel Jerónimo Pinto FERREIRA, natural da Vila da Horta, concelho de Frias de Numão, comarca de Trancoso, filho legítimo de António José da Fonseca da Vila de Muxagata e de D. Maria Joaquina da Vila da Horta, neto paterno de Bernardo Giraldes e de Ana Maria da Vila da Muxagata e materno de José Caetano Pinto Ferreira e de Joana Maria da Vila de Frias de Numão Bacharel em Leis pela Universidade de Coimbra, apresenta-se à Leitura de bacharéis no ano de 1821. (in Iantt, Leitura de Bacharéis, 1817, maço 59, n. ${ }^{\circ}$ 4). Vd. ainda a Relação dos estudantes matriculados na Univerfidade de Coimbra no Anno Lectivo de 1816-1817, p. $33 .{ }^{157}$ Nas três assentadas prestaram depoimento várias testemunhas, devendo ser salientado que nas duas primeiras o resultado foi inquestionavelmente desfavorável para Leite de Castro, situação que já não se repetiu com a terceira tomada de depoimentos que, aliás, se verificou na presença de um segundo juiz substituto. Para a primeira assentada foram arroladas como testemunhas: Luís Bernardo Domingues, casado, ferrador do Rabaçal, de 54 anos (fls. 19-20 verso), José Ferreira casado, ferreiro do Rabaçal (fls. 20 v.-21); António Ayres da Fonseca, casado, proprietário, de 30 anos (fls. 21v-23), Cândida de Jesus, casada com António da Fonseca, de 30 anos (fls. 23-24v), António Alexandre de Sequeira Carneiro, solteiro, filho de Francisco António de Sequeira, proprietário, de 40 anos (fls. 24v-25) e António Ferreira, solteiro, filho de Simão Ferreira, barbeiro, de 28 anos (fls. 25-26) e Anna Antónia, viúva de Francisco José Coelho, proprietário de Poço do Canto, de 36 anos (fls. 
Iniciada a fase de instrução do processo de sindicância, o juiz de direito substituto, Miguel Jerónimo Pinto Ferreira, envia, em 17 de Maio de 1850, um ofício ao Presidente do Tribunal da Relação do Porto onde relata ter procedido às averiguações rigorosas de que foi incumbido, tendo concluído pela veracidade dos factos alegados ${ }^{159}$. Mais informa que Leite Castro não procedeu à entrega de qualquer resposta (doc. 5).

26-26v) e, na segunda (fls. 27-27v), Máxima de Jesus da Silva, solteira, filha de Silvério Joaquim, de 18 anos (fls. 28-29), Francisco Xavier Rodrigues, casado, lavrador, 56 anos (fls. 29-30) e João António Gregório, casado, lavrador de Valongo, de 35 anos(fls. 30-31). À terceira assentada apresentam-se as testemunhas: Benedicta de Almeida, viúva de Matias Dias, vive dos seus bens, de 40 anos (fls. 33-33v.) e Margarida de Cartona, solteira, filha de Matias Dias, de 17 anos (fls. 34-34v). Ao terceiro termo de depoimentos é apensado um conjunto de documentos que dizem respeito aos autos de prisão e óbito, de remoção, em um mês, de suspensão decretada por Leite Castro e de condenação do escrivão do processo, por aquele haver feito avisos aos membros do conselho de família, datado de Penedono, 20 de Abril de 1850; assim como os documentos relativos ao processo de penhora dos bens do Padre Gamboa, o auto de prisão da órfã Máxima de Jesus da Silva, de 28.01.1849, na vila de Penedo fls. 35-35v., a pública forma da ordem de remoção de Máxima de Jesus para casa de Maria Mocinha, viúva de Luís Mocinho, a requerimento do tutor da mesma (fls. 36-37); a certidão de partilha do inventário de Silvério da Costa do povo de Arcos a fls. 38 feita pelo escrivão Manuel d'Assumpção d'Almeida Proença, escrivão, tabelião proprietário do ofício do julgado de Penedo; a certidão lavrada por António Augusto Cézar Ozório, escrivão e tabelião proprietário no julgado de Penedono; a certidão relativa ao inventário de menores por falecimento de João Manuel Cabral (fls. 39) e duas cartas de José Feijó destinadas ao padre João António de Souza, em que pede dinheiro para concessão de livramento (fls. 41-42).

Tal como tinha ocorrido com as testemunhas ouvidas na primeira assentada tomada em 23 de Abril, os termos mandados lavrar pelo juiz substituto Miguel Jerónimo Pinto Ferreira dariam a conhecer a confirmação das acusações apresentadas contra Leite de Castro.

${ }^{158}$ No termo de depoimentos datado de 14 de Junho de 1850 e lavrado perante o juiz de direito substituto Miguel Jerónimo Pinto Ferreira e o escrivão José Maria dias Cardoso de Figueiredo, encontram-se os depoimentos de Manuel do Nascimento Ferreira (fls. 19-19v); António Bernardo (fls. 19v-20); José Maria Pires (fls. 20-20v) e Joaquim Nicolau de Sousa (fls. 20v-21), as quais vêm ratificar os depoimentos anteriormente prestados.

Importa mencionar que enquanto os depoimentos tomados pelo primeiro juiz de direito substituto são prestados a indivíduos que tinham sido ou parte ou testemunhas nos processos então em apreço, de modo que vinham corroborar as acusações que eram feitas contra Leite de Castro, o mesmo já não sucedia com os depoimentos tomados na presença do segundo juiz substituto. Deste modo encontravamse provadas as afirmações de que incorrera em abuso de poder, mandando prender quem se negava a proferir afirmações contrárias à sua vontade, sendo oneradas nas custas processuais excessivas e abusivas. De igual modo, não se encontrava provada a acusação de que teria havido resistência aos actos praticados pelos oficiais de justiça, sendo, ao contrário provada a prisão injustificada da órfã que pretendia casar contra a vontade do tutor.

${ }^{159}$ Em cumprimento dos ofícios de 18 de Maio e 6 de Junho de 1850 foi ordenado que se diligenciasse sobre o conteúdo no auto de investigação realizado pelo administrador do concelho de Figueira de Castelo Rodrigo contra o juiz de direito da mesma, tendo sido ouvidas as testemunhas, conforme termo lavrado no dia 17 de Junho de 1850 e assinado pelo juiz de direito substituto, Miguel Jerónimo Pinto, segundo o qual ... aquele auto que agora devolvo, inquiri 4 testemunhas, as quais, segundo se vê dos seus depoimentos afirmam a veracidade dos factos arguidos e pelas informações particulares que tirei a respeito deles, achei o mesmo. Algumas arguições estão documentadas e comprovadas como é o caso do traslado do mandato de captura contra o regedor da vila, Mathias Nunes Souto, que o juiz declarou 
Entretanto o juiz proprietário de Meda ao ser notificado para responder às acusações que lhe são feitas no âmbito do processo de averiguações remeteria a peça de defesa directamente ao Tribunal da Relação do Porto, em 18 de Abril de 1850 (doc. 6). Mais tarde, em 30 de Maio, e depois de ter dirigido uma exposição, em 12 de Maio, em que se insurge contra o facto de o processo estar fundado numa denúncia anónima da qual ele nem conhece o teor, Leite de Castro apresentará nova defesa em resposta às acusações que lhe são dirigidas em sede do processo de sindicância (doc. 7).

Dado que o sindicado invoca a suspeição do juiz sindicante, Miguel Jerónimo Pinto Ferreira, acusando-o de ser o possível autor da denúncia anónima, é nomeado um novo juiz sindicante, José Cardoso Pinto Leitão ${ }^{160}$ que procederá à tomada de novos depoimentos, feitos sobretudo a testemunhas de qualidade, em 11 e 16 de

culpado por actos praticados no exercício do seu cargo, ainda que não tenha obtido, previamente, a licença do governo de modo a poder mandar emitir a respectiva ordem de captura. A mesma narrativa descreve outro acontecimento semelhante relacionado com o regedor do Poço do Canto.

Neste caso, o mesmo juiz de direito teria chamado a polícia correccional por actos praticados no exercício do seu cargo tendo condenado o citado regedor a 30 dias de prisão, o que foi considerado um excesso e abuso de poder. Igualmente se prova por outro traslado do mandato junto ao auto de investigação igual excesso de jurisdição em mandar intimar o depositário dos géneros penhorados ao património do padre Jerónimo de Gamboa e Sousa à ordem do administrador da vila de Meda para pagamento de décimas e impostos em dívida. Para este efeito são ouvidas as testemunhas: Francisco José Marques, lavrador, de 62 anos, juiz eleito da freguesia do Poço do Canto; António Bernardo, natural da freguesia de Poço do Canto, de 30 anos, casado, carpinteiro; Manuel António do Nascimento Ferreira, natural do Poço do Canto, jornaleiro, solteiro, de 70 anos; Sebastião Machado, natural dos Chãos, de 41 anos, casado, proprietário; Joaquim Nicolau de Sousa, natural de Casteição, proprietário, casado, de 30 anos; José Maria Pires, natural de Meda, de 40 anos, casado, lavrador; Manuel António Ferraz, natural de Meda, viúvo, vive de seus bens, de 58 anos e Ludovino António de Matheus, natural de Meda, de 24 anos, casado, jornaleiro; cujos depoimentos permitiriam concluir pela veracidade das acusações apresentadas.

${ }^{160}$ Aquele juiz deu a cada um dos seus escrivães uma cópia dos artigos daquele papel e isto para dois fins, o primeiro para fazerem algumas emendas e reformas na contagem das custas dos inventários e processos crimes em que fossem excessivas visto ele ser disso arguido. E com efeito, depois de suspenso, esteve fazendo, segundo constou, com os escrivães essas emendas, sendo certo que ele leva mais salários e emolumentos do que lhe pertencem e consente que os seus empregados os levem e grande número de partes se queixam que pagaram mais emolumentos do que estavam, contados nos autos de maneira que por estes não se conhece esse excesso mas o há por levarem mais às partes do que os contados nos autos.

O segundo fim para que deu aos escrivães a dita cópia dos artigos do papel foi para saberem quais eram as testemunhas que neles se nomeavam para prova deles e as prevenirem a favor do juiz, como fizeram de enquanto esteve em exercício publicava havia de culpar as que jurassem nesta diligência contra ele para as aterrar.

É verdade anular o mesmo juiz os inventários que o primeiro substituto fez enquanto esteve vaga a comarca de juiz proprietário tomando por fundamento para os anular que não era juiz competente para os fazer, mas o juiz ordinário; e procedeu a segundos inventários com as vistas nos emolumentos deles porque sem os herdeiros ou as partes interessadas tal requererem o juiz de direito por assim dizer oficiosamente os anulou, sendo bem óbvio que foi com as vistas nos emolumentos.

É quanto se oferece dizer a Vossa Exa. 
Julho ${ }^{161}$. Dos últimos depoimentos prestados é possível concluir pela manifestação de probidade face ao juiz de direito, ora sindicado, negando-se o uso de qualquer meio intimidatório ou abusivo daquele para com as testemunhas, contra as quais nunca havia dirigido termos injuriosos e que apenas poderiam, em última circunstância, ter sido ásperos. Deste modo, apenas restam como provados o auto de prisão contra Máxima de Jesus e a anulação dos processos de inventário.

Conclusos os autos de sindicância, em 20 de Julho, é remetida toda a documentação ao Presidente da Relação do Porto que o reencaminha, por sua vez, ao Ministro dos Negócios Eclesiásticos e de Justiça, em 30 de Julho de 1850.

Em 31 de Março de 1851 é emitido o parecer da Procuradoria-geral da Coroa que concluiria que em virtude de haver coerência entre as respostas dadas por Leite de Castro e os testemunhos prestados perante o segundo juiz substituto, não é possível concluir pela prática de actos criminosos. Por este motivo e, uma vez, instalada a dúvida, torna-se

... absolutamente necessario e indispensável mandar-se novamente informar a este respeito a Presidencia da Relação do Porto, ordenando-se-lhe mais positivamente, que encarregue ao Juiz de Direito d'uma das Comarcas mais próximas à de Meda e não a nenhum dos Substitutos do juiz de Direito desta, a escrupulosa indagação de umas e de outras arguições, e que ao mesmo tempo lhe recomende, se haja nesta diligencia com o maior acerto e circumspecção, não se limitando a inquirir as pessoas que tenham sufficiente rasão de sciencia

${ }^{161}$ José Cardoso Pinto LEITÃo é natural da Prova, Guarda. Do registo de aluno matriculado no $5^{\circ}$ ano jurídico no ano lectivo de 1848/49 sabemos ainda que é filho de Ulbino de Campos Cabral (vd. Relação e Indice Alphabetico dos estudantes matriculados na Universidade de Coimbra no anno lectivo de 1848/49, suas naturalidades, filiações e moradas, Coimbra, Imprensa da Universidade, 1848, p. 28). ${ }^{162}$ Em 11 de Julho de 1850, é realizada nova assentada, em Meda, na presença do segundo juiz substituto de direito, Dr. José Cardoso Pinto Leitão e do escrivão, José Maria dias Cardoso de Figueiredo. São arroladas novas testemunhas, a saber: o reverendo Sebastião Cardoso de Meneses, abade da vila de Marialva, de 50 anos; Manuel d'Abrunhosa Saraiva, casado, proprietário do lugar de Outeiro dos Gatos, de 54 anos; o reverendo Carlos Maria de Frias Pimentel Abraão, vigário arcipreste da vila de Meda, de 48 anos; o Reverendo João António Pimentel, pároco da freguesia do Rabaçal, do julgado de Marialva, de 37 anos; Bernardino António Gomes Amado, viúvo, proprietário de Outeiro dos Gatos, de 54 anos; o Reverendo Padre João Maria de Gamboa Pimentel, abade da freguesia do Aveloso, de 40 anos; António d'Anciães Proença, casado, proprietário da freguesia do Aveloso, de 35 anos e Luis Ignacio de Seixas e Vasconcelos, solteiro, proprietário do lugar de Cancelos, de 29 anos. Segue-se a certidão de corpo de delito tirada da situação ocorrida em Poço do Canto com o respectivo processo; a certidão de querelas públicas dada contra João António d'Almeida; a certidão que dá a conhecer o óbito do reverendo Jerónimo de Gamboa Sousa e Castro do Poço do Canto e as dívidas deixadas por este; bem como o processo de penhora.

Em seguida, em 16 de Julho de 1850 são inquiridas, em Meda, as testemunhas: José António de Sousa, casado, proprietário da vila de Meda, de 41 anos; Manuel António de Figueiredo, viúvo, proprietário da vila de Meda, de 51 anos; José António d'Abrunhosa, casado, proprietário da vila de Meda, de 42 anos; José Joaquim Monteiro de Figueiredo, casado, serralheiro da vila de Meda, de 29 anos. 
de cada um dos factos, e sejam comtudo insuspeitas, e dignas de credito por sua probabilidade, e sã consciencia, mas procedendo também aos convenientes exames nos processos, e livros respectivos, que se apontam em prova de taes arguições, e praticando tudo o mais, que o seu zelo lhe sugerir, tendente a descobrir a verdade, em ordem a que, não folgue o crime na impunidade, quando realmente o haja, nem gema tão pouco a innocencia opprimida pela calumnia de ignotos delatores quando aquelle não existe.

\section{Conclusão}

Em outras circunstâncias, como as que ocorreriam nos anos de 1847 e 1850, sabemos que a conduta de Leite Castro chegaria a ser apreciada quer no Tribunal da Relação quer no Supremo Tribunal de Justiça, tendo o resultado final sido a ilibação do arguido, no entanto, no caso de Meda, não temos conhecimento de que tenham sido empreendidas quaisquer medidas complementares então sugeridas pelo procurador-geral da Coroa não tendo o processo tido qualquer seguimento. Por este incidente, o juiz de direito nomeado para Meda não seria alvo de qualquer punição, ou sequer de uma transferência extraordinária, o que quer, igualmente, dizer que este incidente não produziria quaisquer repercussões na sua carreira judiciária. 


\section{APÊNDICE DOCUMENTAL ${ }^{163}$}

\section{Doc. 1}

Sendo algumas camaras da Comarca da Meda e fora della como as de Foz Coa e Authoridades Adm.as dirigido suas representações e queixas contra o Juiz de Direito da Comarca José Januario Teixeira Leite de Castro a Sua Magestade A Rainha pelo Ministério da justiça nada tem resultado, e como os seus excessos, arbitraried.as e despotismos não cessão, por isso dirijo a V. Ex. ${ }^{a}$ a inclusa representação e queixa contra elle, a qual ainda q. anonima não deixa de ser verdadeira para a fazer presente à mesma Aug.ta Senhora a fim de q. ou seja demitido como merece, ou transferido para outro logar, porq. a paciencia, e soffrm.to tem seus limites; e os povos cançados de o aturarem podem cometer algum excesso, q. se deve evitar.

D. G. $a$ V. Ex. ${ }^{a 164}$

\section{Doc. 2}

\section{A participação do administrador de concelho, Miguel António de Figueiredo Vasconcelos, de 10 de Março de 1850}

Por me parecer de urgencia a brevidade de chegar esta a presença de V. Ex $x^{a}$. peço a precisa Licença para representar a V. Ex. ${ }^{a}$ directamente, sem ser por via do Ex.mo Governador deste Districto o que acaba de acontecer com o actual juiz de direito desta Comarca, José Januário Leite de Castro, q he pela forma seguinte.

O R.do Jeronimo de Gamboa Pinto e Souza, que viveu no Logar d'Poço do canto deste Concelho estava em Dezembro de 1849 a dever á Fazenda Nacional125\$280 r. de Décima, e impostos annexos pelos annos de 1845 athé 1848, e ás Congruas de differentes Parochos $15 \$ 600 \mathrm{r}$. dos mesmos annos, e $2 \$ 370$ r. de contribuição para o sustento dos expostos do anno de 1845 , cujo atrazo de pagamento preveio da guerra civil principiada em 1846, em que fui obrigado a retirar-me desta Villa, aonde não pude voltar senão em Setembro de 1847, sendo precizo consummir muitos tempos, para preparar os trabalhos para se principiar na arrecadação dos rendimentos Publicos, em que com m.ta moderação se tem precedido a fim de não inflamar, antes chamar, antes chamar, á amizade destas Ligitimas Aucthoridades os povos que um chefe de guerrilha desta Villa, tinha illudido, e desviado de seus deveres: e observando eu em Novembro de 1849, que o referidoPe. Se achava com aquellas dividas, dei ordem ao Escr.am. desta Adm. Am para passar as precisas Certidoes para administrativam.te ser cumplido ao pagamento, que sendo-me apresentadas em Dezembro do dito anno, lhes lancei despacho para intimações do pagamento dentro dos cinco dias, tendo porem o d.to P.e cahido na cama muito doente, do q. se seguio ser dado á sepultura no dia onze de Janeiro proximo findo, e ficarem na casa q. habitava, seu irmão Carlos António de Gamboa e Souza, e alguns filhos deste, e sendo o dito P.e. uzofructuario de boa porção de beins, que por sua morte devião passar para umas sobrinhas e tendo estes beins alguns olivaes, que o mesmo P.e já tinha mandado varejar e recolhido a azeitona na azenha e andando a fazerse o azeite quando faleceu, eu convidei o referido Carlos António pra pagar, sem ser precisa penhora, ao que elle annuio: porem passados algus dias, tive noticia, que elle tinha ajustado com o juiz de direito, de não pagar couza alguma, e de requerer que procedesse a inventario no que elle quisesse dizer, que ficou pertencente ao P.e, e assim fez, retirando primeiro o q. bem lhe pareceu: por isso mandei proceder nos termos de Lei, para se fazer penhora, que indo para a verificar o Escr.am da Adm.am, no empedimento do Escr.am de Fazenda, ara isso lhes dificultarão a entrada na Adega do azeite, aonde apenas

${ }^{163}$ É mantida a grafia original dos documentos que ora se transcrevem.

${ }^{164}$ No mesmo documento, na margem esquerda, foi inscrito Os papeis relativos demonstram que se tem tomado as provid. ${ }^{\text {as }}$ necessárias, in Iantt, MNEJ, maço 363/5. 
havia quinze almudes, porq. o mais já estava retirado, por isso o escrivão recorreu á assistencia do Juiz Eleito da Freguesia com duas testemunhas em conformidade com o Art. 667, $\$ 3^{\circ}$ da reforma Judicial para a abertura da porta, e formou o auto da penhora. O juiz, porem, que desde a sua entrada nesta Villa se declarou inimigo irreconciliavel de todos os Empregados Administrativos, culpando e prendendo Regedores, e atormentando a todos, sem a previa Licença do Governo e Sua magestade, tem agora espalhado, que vai tirar devaça contra o Juiz Eleito, escrivão e Official de diligencias para os culpar pela entrada na referida adega de azeite, de forma que todos andão medrosos, e não se encontra, quem queira empregar-se no Serviço Administrativo, sendo pessoas amigas da Ordem, e tranquilidade Publica, do q. resulta, que o Adm.orneste Concelho he e será inutil, enquanto aqui existir um tal juiz, por q. todos receião serem culpados, pois ainda q. tem o recurso para a Relação, tem contudo de estarem prezos, suffererem vexames, e fazerem grandes despezas, q. so rezultão em favor do Juiz, e Escrivaes, como aconteceu em Fevereiro de 1848.

Para evitar este inconveniente do Serviço tam illegal, e demorozo, he q tomei a prezente deliberação e Supplicar a V. Ex as Providencias, pelo menos, de q não se conceda Licensa áquelle Juiz, tam conhecido pellos seus excessos absolutos, para proceder a Devaças tam arbitrarias e inlegaes.

D.s G.de a preciosa vida de V. Ex ${ }^{a}$ p.r dilatados annos

Meda 10 de Março de 1850

Ill.mo e Ex.m ${ }^{\circ}$ S.or Ministro dos Negócios do Reino

Secretario d'Estado

O Admn.or do Com.co

Miguel An.to de Fig.do Vas.los ${ }^{165}$

\section{Doc. 3}

Anno do nascimento de Nosso Senhor Jesus Christo de mil oitocentos cincoenta, e aos dezanove dias do mês de Abril do dito anno nesta Villa e concelho da Meda, e casas da Camara Municipal do dito Concelho, aonde compareceo o Administrador do concelho de Figueira de Castello Rodrigo Francisco da Guerra Bordallo da Fonseca, comigo escrivão de seo cargo para efeito de proceder a este auto de investigação em virtude do officio do excellentissimo Senhor Governador Civil deste Districto de vinte e sete do mês de Março ultimo, sob numero trezentos e seis, a cerca dos factos constantes da representação que o Administrador deste Concelho levou à presença do Ministro e Secretário d'Estado dos Negócios do reino que em sustância he o seguinte = primeiro: que o Administrador do concelho da Meda mandou penhorar o azeite que havia em casa do falecido padre Jerónimo de Gamboa Pinto e Souza e que lhe não quizerão abrir as portas, sendo por isso preciso ser arrombadas com assistencia do Juiz Eleito, e que depois disso o Juiz de Direito desta Comarca José Januario Leite de Castro publicou que havia de culpar tanto o juiz como o Escrivão da administração e oficial de Diligencias por irem fazer a penhora = segundo que no dia dezassete de Março deste anno andando o azeite penhorado, digo, andou o azeite penhorado em Praça para se arrematar, porem não se arrematou por não haver lançadores por temerem que lhe não foce entregue por causa de um mandado do Juiz de Direito desta Villa, que mandou ao depositário que não entregace o referido azeite sem ordem sua, apesar de estar penhorado pela administração do Concelho para pagamento de Decima e impostos anexos que devia à Fazenda o dito padre Jerónimo de Gamboa = terceiro que o referido juiz de direito he perseguidor dos empregados Administrativos que tem prendido alguns e os tem processado sem licença do Governo de Sua Magestade em resultado do exercício de seos cargos $=$ E para se examinar a verdade a cerca dos referidos factos mandou o referido Administrador do Concelho de Figueira de Castelo Rodrigo vir à sua presença as pessoas que lhe contou terem mais razão de saber dos mesmos a quem tomou as declarações juradas na forma seguinte. ${ }^{166}$

${ }^{165}$ In Iantt, MNEJ, maço 363/5.

${ }^{166}$ In Iantt, MNEJ, maço 363/5. O escrivão é José Maria Dias Cardoso de Figueiredo. 


\section{Doc. 4}

Ill.mo Ex.mo Senr. ${ }^{167}$

Em cumprimento do que me foi ordenado em Portaria expedida pelo Ministério a cargo de V. Ex. ${ }^{a}$ em 19 de Março ultimo, encarreguei o Administrador do Concelho de Figueira de Castello Rodrigo, de passar ao Concelho da Meda, e conhecer dos factos que fazem o objecto da representação, que V. Ex. ${ }^{a}$ dirigiu o Administrador da ditta Villa, e em desempenho d'esta Comissão, procedeo ao Auto d'investigação que tenho a honra de pôr na presença de V. ex. .

Por este Auto, e pela Informação do sobredito administrador conhecerá $V$. Ex. ${ }^{a}$ que athé hoje ainda não houve por parte do Juiz de Direito da Meda o procedimento judicial que se receia empregue contra os Funcionários Administrativos pelo facto por eles praticado no exercício de suas funções, com o fim de tornarem effectiva a penhora nos bens dos herdeiros do reverendo Jeronimo de Pambôa Pinto, do poço do canto, para pagamento dos tributos ao Estado e Congruas de que aquelle era devedor, porem o receio da parte do Administrador, he tanto mais fundado, quanto he certo que o mencionado Juiz ameaça aquelles empregados com esses procedimentos, que aliás tem levado a efeito, com outros em iguaes circunstancias.

Este Magistrado inimigo declarado do governo, procura todos os meios d'hostilizar, e um deles he por certo emperar, e tornar nula a acção administrativa, processando os seus Empregados por factos practicados no exercício de suas funções, sem previa licença e incutindo n'elles tal terror, que as delligencias que a bem do Serviço reclama, se não fazem tendo em uma espécie de coacção o Administrador do concelho, e todos os Empregados seus subalternos, e se o Governo não tomar medidas tendentes a reprimir tais excessos, e a conter este juiz nos limites de suas atribuições legaes, respeitando também a das Suthoridades Administrativas, não estará longe o momento em que não haja no Concelho da $M e d a$, e nos mais da comarca, quem queira servir os cargos administrativos em vista d'isto $V$. Ex $x^{a} r e-$ zolverá o que tiver por conveniente.

Deos Guarde a V. Ex ${ }^{a}$ Guarda 3 de Maio de 1850

Ill.mo Ex.mo Senr. Ministro e Secretário d'Estado dos Negócios do Reino

O Governador Civil

João Chrisostomo Freire Corrêa. ${ }^{168}$

\section{Doc. 5}

\section{Ministério do Reino \\ Secretaria Geral \\ $1^{a}$ Rep.ção \\ Livro $4, n .^{\circ} 86$}

Ill.mo e Ex.mo Snr.

Merecendo séria atenção o procedimento acintoso e incurial que o juiz de direito da Comarca de Meda José Januário Leite de Castro emprega com alguns dos funccionários administrativos dos diferentes Concelhos da mesma Comarca tenho a honra d' enviar à presença de V. Ex. ${ }^{a}$ a representação que sobre o assumpto me dirigio o Administrador do Concelho, e a informação que recebi do Governador Civil do districto da Guarda, com o auto de notticia lavrado pelo Administrador do concelho da Figueira de Castello Rodrigo, para que se digne de providenciar a similhante respeito como entender acertado, sendo, como acredito, exacto o que se se representa, assim de que as aucthoridades administrativas possão livremente exercer suas funções.

${ }^{167}$ Em papel timbrado do Governo Civil da Guarda, $1^{\text {a }}$ Repartição, n. ${ }^{\circ}$ 125. Apresenta o mesmo documento a seguinte inscrição: O D. 18. N.479 D.G.

${ }^{168}$ In Iantt, MNEJ, maço 542/5. 
Deos Guarde a V. Ex. ${ }^{a}$

Secretaria d'Estado dos Negocios do Reino em 8 de Maio de 1850

Ill.mo e Ex.mo Snr. Ministro e Secretario d'Estado dos Negócios Ecclesiasticos e da Justiça

Conde de Tomar ${ }^{169-170}$

\section{Doc. 6}

\section{Illmo e E.mo Sñr.}

Fui encarregado pelos dois officios de V. Ex. d'oito do mez ultimo, de proceder ás mais minuciosas averiguações acerca dos artigos da queixa que contem o papel que accompanhou hum daquelles off.os que agora devolvo incluzos, dirigido a Sua Magestade A Rainha contra o juiz de Dir.to desta Comarca José Januário Teixeira Leite de Castro, e inquirir testemunhas de probidade que declarem a verdade de taes factos e depois de vir receber as respostas do m.mo juiz áquellas varias arguições, para cujo fim $V$. E. ${ }^{a}$ lhe dirigira por cópia aquelle papel na mesma data, segundo me fez saber em hum dos m.mos off. ${ }^{\circ}$ enviar tudo a V. $E^{a}$ com a minha informação. Em cumprimento disto tenho a dizer que o juiz não me entregou a resposta que $V$. E. ${ }^{a}$ lhe ordenou e que procedi a aquellas minuciosas averiguações e achei tanto por algumas das testemunhas da inquirição incluza, como pelas informações particulares, que tirei, são verdadeiros os factos dos mesmos artigos. Provando-se de mais a mais pelos documentos $n$. ${ }^{\circ} 1$ e 2, que manda prender despoiticamente sem culpa formada como fez com a órfã Máxima de Jazuz do Rabaçal e não do Carvalhal, de que falla o artigo $2^{\circ}$ do papel, que a teve preza na cadeira de Penedono desde 28 de Janeiro athé 27 de Fevereiro do anno próximo findo, em que a mandou remover para caza de Leanor Paes, aonda está ainda depozitada sem outro motivo mais para tal procedimento do que por pretender cazar-se, como jurão as testemunhas a este artigo, eella mesma no seu depoimento o diz.

Acrescendo mais a respeito desta orfa, que ella não he do julgado da Meda, mas do de Marialva, e ao juiz ordinário desta villa, e não ao juiz de direito de Meda he que pertence a inspecção sobre ella, $e$ por conseguinte foi huma arbitrariedade, hum excesso de jurisdição o procedimento do juiz de Dir. ${ }^{o}$ para com ella. Informando-me algumas pessoas de probid.e de Penedono padece nota com hum filho da caza onde está depozitada, com o qual tem querido cazar, mas o Juiz de dir. ${ }^{\circ}$ tem obstado a isso.

Prova-se também pelo documento $n .{ }^{\circ} 3$ que arbitrariamte. se suspendeu o Escrivão da Villa de Penedono Manoel d'Assumpção Proença por fazer avizos aos membros de hum conselho e família e pelo mesmo motivo multou em dez tostões o outro escrivão da mesma Villa António Augusto cezar Osório para a Fazenda nacional, quando pelo $n .^{\circ} 3$ do art. $4^{\circ}$ da nova tabella dos Emolumentos e sallarios judiciários lhes pertence fazer por avizos e não ao official de diligencias, como disse o juiz para essa suspensão e multa.

Prova-se igualm.te assim pellas test.as como pellas trez cartas juntas á inquirição, o $5^{\circ}$ artigo da queixa, vendo-se destas que não admittia aos réos Livramento sem depositio de dinheiro, e que o padre António de Souza se vio obrigado para entrar em Livramento a depositar por si e pelos outros corréos sete moedas. E posto que estas cartas não são do juiz, mas do escrivão do processo, contudo claramte deprehem das pressões dellas que o juiz de diro era quem assim o ordenava ao escrivão.

Nos livros dos termos de fiança dos indiciados em crimes achei que o fiador que elles davão se obrigava não so a aprezenta-los em juizo, mas como principal pagador da multa, pena e custas em que fossem condemnados, quando a Nova Reforma Judicial cap. $5^{\circ}$ em que trata das fianças, não obriga o fiador ao pagamento das custas do processo criminal, mas somente a aprezentar o Réo em juízo quando the for ordenado, e não o aprezentando pagar a fiança taxada, e os termos lavrados por esta forma nos ditos livros corroborão a verd.e do facto allegado no $5^{\circ}$ artigo do mmo papel e o depoimento da test. ${ }^{a}$ Antonio Aires da Fonseca em que diz que ficara por fiador de seu cunhado Manoel Joaqwuim Ferr. ${ }^{a}$ e fizera hum titulo em que se obrigava também pelas custas do processo criminal.

169 Assina.

${ }^{170}$ In Iantt, MNEJ, maço 363/5. 
Aquelle juiz deo a cada hum dos seos escrivães huma copia dos artigos daquelle papel e isto para dois fins, o $1^{\circ}$ para fazerem algumas emendas e reformas na contagem das custas dos inventários e processos crimes em que fossem excessivas, visto ser elle disso arguido. E com effeito depois de suspenso, esteve fazendo, segundo constou, com os escrivães essas emendas; sendo certo, que elle leva mais salários emolumentos do que lhe pertencem e consente que os seus empregados os levem, e grande numero de partes se queixão que pagarão mais emolumentos do que estavão contados nos Autos, de maneira que por estes não se conhece esse excesso, mas o há por levar em mais às partes do que os contados nos Autos.

O segundo fim para que deu aos escrivães a dita cópia dos artigos do papel, foi para saberem quaes erão as test.as que nelles se nomeavão para provas d'elles e as prevenirem a favor do Juiz, como fizerão, e emquanto esteve em exercício publicava havia de culpar os que jurassem nesta diligencias contra elle para as aterrar.

He verdade annular o mm. ${ }^{\circ}$ Juiz os inventários que o primeiro substituto fez emquanto esteve vaga a comarca de juiz proprietário, tomando por fundamento para os annular que não era juiz competente para os fazer, mas o juiz ordinário; e procedei a segundos inventários com as vistas nos emolumentos delles, porque sem os herdeiros, ou as partes enteressadas tal requererem, o juiz de Dir. ${ }^{\circ}$ por assim dizer officiozamente os annullou, sendo bem obvio que foi com as vistas nos emolumentos.

He quanto se me offerece dizer a $V . E^{a}$.

D.s Gde a V. E. ${ }^{a}$

Meda 17 de Maio de 1850

Ill. $m^{\circ}$ e E. m $^{\circ}$ Sñr Conselheiro Presidente da Relação do Porto

O Juiz de Dir. ${ }^{\circ}$ Substituto

Miguel Jeronimo Pinto Ferreira ${ }^{171}$

\section{Doc. 7}

\section{Ill.mo e Ex.mo Senhor}

Tenho presentes dous officios de V. Ex. ${ }^{a}$, um datado de 22 de Junho próximo passado, e outro de 25 do mmo. com aquelle recebi igualmente um processo informatório de queixa contra o juiz de direito d'esta comarca- José Januário Teixeira Leite de Castro, a que procedeo o seu primeiro substituto: do mesmo processo $V$. Ex. "me manda tomar conhecimento, pelos motivos de suspeição que pezão sobre o dito substituto. Com o fim, pois de conhecer a verdade em taes arguições feitas contra o juiz de direito, mandei intimar as pessoas mais qualificadas desta comarca, para que alheias a qualquer sentimento de politica, ou parcialidade, respondessem nos differentes artigos de accuzação, cuja inquirição devolvo a V. Ex. ${ }^{a}$, e igualmente a outra relativa aos autos de investigação / que constavão do $2^{\circ}$ officio de V. Exa/ juntando-lhes também alguns documentos necessários, o q tudo remetto a $\mathrm{V}$. Ex ${ }^{a}$ com todos os mais papeis que tenho recebido a tal respeito.

Deus Guarde a V. Ex ${ }^{a}$

Meda 20 de Julho de 1850

José Cardoso Pinto Leitão

Ex.mo Snr. Bernardo José da Motta Conselheiro Presidente da Relação ${ }^{172}$

\section{Doc. 8}

\section{A representação apresentada pela Presidência da Relação do Porto, de 9 de Abril de 1850}

\section{Cópia}

Senhora. A Vossa Magestade se derige esta representação, e queixa contra o Juiz de Direito da comarca da Meda José Januário Teixeira Leite de Castro pelos factos insólitos, e escandalosos por elle

${ }^{171}$ In IANTT, MNEJ, maço 556/7.

${ }^{172}$ Ibidem. 
praticados no exercício de suas funções que sendo muitos carecem de boa ordem na sua dedução. $1^{\circ}=$ Abusa do seu poder prendendo as testemunhas, que não jurão o que elle quer, e manda escrever o que ellas não dizem, como aconteceu na querela de suposta resistência feita aos officiaes de seu Juizo José Cippriano Pinto e José Maria, sendo as testemunhas inquiridas no processo preparatório da querela Joaquim Nicolau = Manuel d'Almeida Junior = Maria Dorotheia $=e$ Thereza de Jesus de Conceição, as atormentou, e ameaçou por não jurarem virão fazer a resistencia, chamando aos dous primeiros marotos e brejeiros, e às mulheres putas e bebadas, chegando mais ao excesso de as mandar meter em a loja da casa da Camara da Villa da Meda por não haver cadê,e ali estiveram todo dia, e à noute as mandou soltar pagando cada uma ao Official de Deligencias, que as levou 720 r.s! E ainda aqui não parou o seu despotismo pois nas Audiencias geraes do $2^{\circ}$ semestre de 1849 sendo inquirida oralmente no plenário daquela querela a dita testemunha Manuel d'Almeida, e sendo-lhe lido seu depoimento escripto, e por que disse, não tinha sido esse, novamente o insultou, e mandou metter naquela loja pagando ao Official de Deligencias 240 r.s. As testemunhas do mesmo plenário Leocadia filha de Manoel d' Aguiar e Josefa filha do Alfaiate de Confeição por dizerem por dizerem que os seus depoimentos estavão escriptos por diferente modo, do que tinhão jurado as injuriou de palavras, e mandou para a mesma loja pagando cada uma ao mesmo oficial 240 reis. $2^{\circ}$ Prende arbitraria, e despoticamente como fez a uma orphã do Carvalhal julgado de Marialva, que andando com vistas de cazar com individuo, que o tutor não queria a mandou elle juiz por este motivo meter na cadêa de Penedono quatro legoas de distancia da sua terra, e ali a teve dous mezes, cuja prizão foi cauza da desgraça della pela amizade illicita que ali tomou. $3^{\circ}=$ Nas audiências geraes do $2^{\circ}$ semestre de 1849, insultou e descompôs com palavras as mais injuriosas um jury porque não deu por provados os quesitos que elle juiz lhe ditou, até dezia aos jurados, o seu voto a respeito dos quesitos, que devião julgar, ou não provados, de maneira que um jury dando por não provados os quesitos convocou outro, e o $2^{\circ}$ com mêdo delle os deu por provados. $=4^{\circ}=O$ mesmo juiz derigio palavras de injuria, e afronta a uma menina honesta, e bem comportada chamada Damazia filha de Benedita viúva, da Meda por não jurar o que elle queria em uma policia correcional, em que fora dada por testemunha d'accuzação, ficando a sua Mãi que ali estava por a ter acompanhado, e os mais espectadores corridos de pejo, e vergonha com palavras tão afrontosas, $e$ ameaçou dizendo-lhe que atirava com ella de palanquim abaixo. $=5^{\circ}=$ Não admitiu os reos a livrarem-se ainda que fossem pobres sem deposito de dinheiro; em suposto crime de que se falla no Art. $1^{\circ}$ ficando pronunciados vários indivíduos de Casteição, e como só um destes tinha meios para pagar as despezas do livramento, e as outras erão pobres, obrigou o mais abonado a depositar sete moedas para entrar em livramento, sem as quaes o não queria admitir de forma, que pagou por si, e pelos outros corréos, e afora este dinheiro levou ao mais abonado $10 \$ 000$ r.s pela fiança, e sem que pagassem as custas do processo preparatório os não admittiu a livramento, e no termo de fiança obrigava ao fiador ao pagamento dos do plenário. $=6^{\circ}=$ Ficando pronunciado João Niculau David d'Outeiro de Gatos em querella de ferimento leve e como o juiz se recuzasse admiti-lo a livramento com fiança lhe fez um requerimento para o admitir a livrar-se de baixo della, que mandou despachar por seu cunhado António Ferreira, e ao mesmo tempo levava outro requerimento para aggravar do juiz no cazo de lhe indeferir aquelle em que pedia fosse admitido a livrar-se com fiança. Entregando o dito Ferreira ao juiz o $1^{\circ} \mathrm{re}-$ querimento pegou este nelle, e com ímpeto o ameaçou para cima da meza, e dizendo-lhe aquelle - se não the despachava o requerimento pois os Letrados lhe dezião, tinha logar a fiança, respondeu-lhe não lhe importavam os Letrados que viessem cá obriga-lo. Então entregou-lhe o $2^{\circ}$ requerimento e vendo era para aggravar o pouzou de cima da meza com grande ímpeto e colera, e entrou para a salla contigua aquella em que estava. Vendo aquelle Ferreira a maneira do juiz, e receando-se delle se foi embora, sem esperar pelo despacho. No dia seguinte áquelle em que teve logar este sucesso mandou o juiz chamar o culpado João Nicolau para que desse fiança e quando estava dando-lhe lhe diz = Então seu cunhado não esperou pelo despacho? Todo requerimento o tem, bom ou mau= e o que the volveu em resposta = como elle desconfiou dos modos, e maneiras de V. Sa, por isso não esperou por elle; oh! Lhe diz o juiz = Não que elle é macaco do rabo pelado= Estes factos mostrão que é um juiz despótico. $7^{\circ}$ Chamou a policia correcional o Regedor do poço do canto Francisco Coelho e o condenou a trinta 
dias de prizão por actos praticados no exercício do seu cargo; quando não podia ser sem licença do Governo de Vossa Magestade segundo a Circular do Ministério do reino de 19 de Março de 1843, mandada observar pela do da justiça de 29 do mesmo, e o obrigou a pagar quatorze cruzados novos (a) = $9^{\circ}$ Annullou os inventarios, que o substituto do juiz de Direito Manuel Jerónimo fez em quanto esteve vago o Lugar do Juiz proprietário, e fez segundos, unicamente com as vistas d'extorquir os emolumentos dos segundos Inventarios aos infelizes órfãos, tomando por pretexto (frívolo) que os ditos forão feitos por juz incompetente!!! 0100 por assestir á carregação e descripção dos bens nos Inventários leva emolumentos, ou salários sem assistir a ella contra o disposto no titulo 11 Artigo $4^{\circ}$ da nova Tabella dos emolumentos pelo que na forma della deva perder o emprego.

Pelos factos expostos nos 10 Artigos, que são verdadeiros se suplica a Vossa Magestade como graça especial haja de livrar a Comarca da Meda d'um tal juiz, odiado execrando por todos os habitantes della como o foi em Villa Pouca ${ }^{173}$, que o dia da sua sahida foi ali d'inteira satisfação, regozijo acompanhado de foguetes em demonstração della. E dignando-se Vossa Magestade a atender a esta supplica como se espera postos anonima as provas pedirão as bênçãos sobre Vossa Magestade, e seu Governo; porque eles não podem sofrer por mais tempo com tal juiz, pois tendo algumas Camaras da comarca, e fora della, como a de Foscoa, e Authoridades Administrativas dirigido suas representações contra elle, pelo Ministério da Justiça, como nada tenha resultado, motivo porque agora se faz esta a Vossa Magestade. Deos Guarde a Vossa Magestade por dilatados anos como havemos mister.

Esta conforme. Secretaria da Presidencia da Relação do Porto em 9 de Abril de 1850.

O Secretario

Manuel Joaquim Azevedo Vieira

$8^{\circ}$ Nos processos crimes levou aos reos emolumentos excessivos como aconteceu com a certidão de que se falla no art. $5^{\circ}$ ao Manoel Braz do Avelozo, que importarão as custas do livramento, de cada um dos processos em perto de $40 \$ 000$ r.s = pois é o seu rifão 0 ou boa, ou má querela trinta mil reis para ella.

Vieira $^{174}$

\section{Doc. 9}

\section{Resposta de Leite Castro, datada de Meda, 18 de Abril de 1850}

Recebi n'este correio o officio que V.Exa. em data d'oito do mêz que corre teve a bondade de dirigir-me, e com elle um papel (como no mesmo officio de dez) mas a que eu pouca (...) contra a minha umilde pessoa, à Sua Magestade dirigida, delação que contem factos que quando verdadeiros manxarião a minha caraque a despeito de todas as assintozas perseguições conservo sem manxa. Não contém a cópia que me foi remetida à data, nem a assinatura do meu vil delator, entendo ser do meu dever do meu brio e onra opor-me a um proceder tão desleal como injurioso em se me mandar responder a uma delação anonyma por isso baziado na proposizão do art. $940^{\circ}$ da ref, Jud. Exponho a V. ex este meu sentir a fim de que se me enviar uma cópia do tal papel e assinatura.

Assegurando ao mesmo tempo a V.Ex $x^{a}$ que eu aprecio em muito qualquer ensejo que se me offereça em que possa mostrar que tenho mais probidade em minhas botas só que têm na cara todos os Marções tagareiros d'estes sitos.

Duvido alem d'isso entregar a minha resposta ao Substituto Miguel Jerónimo Pinto Teixeira, por quem como V. Ex a de ver aprovado por documentos que no tempo em que elle teve a jurisdição de juiz de direito n'esta comarca que foi desde Maio de 1846 até ao início de Novembr de 48 em que eu tomei posse do lugar a justiça tenha daqui desaparecido. Até $V$. Ex $x^{a}$ ver que os assassinos e ladrões roubavão

${ }^{173}$ Refere-se à questão verificada em Vila Pouca de Aguiar, $v d$. dados biográficos.

${ }^{174}$ In Iantt, MNEJ, maço 542/5. 
de dia e no meio das povoações e praças a que se não de tal e se acazo se conhecia tudo terminava em bem enviando dinheiro.

Até V. Ex $x^{a}$ ver que se ouvião as querelas de morte e alguns réos a 4, 5 e 6 moedas e uma ouve que custou 3 r. foi a José Maria Gomes do lugar da Ferronha. Até V. Exa. ver que ouve inventários que se não fizerão e pagarão. Até $V$. Exa. ver que este juiz não passou a jurisdição orfanológica para o juiz ordinário ordenando-os elle dar-se o seu começo dando d'esta parte os emolumentos ao juiz ordinário e cauzando graves transtornos aos órfãos, como já tem cauzado. Até ver os subdelegados a levarem tanto como os juizes ordinários d'hirem assistir a descripções dos bens dos inventários. Até V. Exa. Ver inventários principiados com papeis da morte do inventariado e outros pois para se concluir e assentar sem conto em um bem pequeno, encontrei seis e uma d'ellas com duas verbas, um carro forrado e um relógio avaliado em 3:200r, era o inventário de Luiza de Locena Cardozo, do Rabaçal.

Até V. Ex ver que os escrivães dos juizes eleitos e alguns destes ficavão com as multas impostas aos gados e contratavão com os pastores por queijos e lã. Até $V$. Exa ver que alguns escrivães dos julgadores levam caminho todas as vezes que hiam a casa do juiz que assistia na sua aldeia fora da villa. Até $V$. Ex $x^{a}$ ver que se mandou para casa da prizão uma ré pronunciada em crime de morte sem que o processo fosse sentenciado. Até $V$. Ex $x^{a}$ ver e o público ver outras muitas couzas d'este juiz.

Cuido pouco a pouco de remediar tantos males e os autores d'elles como sabem que para mim não há empenhos nem dádivas a que os omens que por aqui tudo mandavão, não mandão em mim, é mui natural a sua perseguição com que me onro. Eu já tinha sido prevenido, ainda que gratuitamente que Miguel Jerónimo Pinto Ferreira e Sebastião Morgado Coelho escrivão já suspenso por suas abilidades cuidavão em ver se o governo d'aqui me transferia, no que eu de bom grado convinha. Parece pois que avendo quatro juizes substitutos não deve ser o indicado pelo que deixo dito o informante: no em tanto envie V. Exa . a quem quizer a minha resposta por que a minha conduta está superior a toda a calúnia, mas eu feita que seja heide remette-la directamente a essa Presidencia.

Deus G.de a V. Exa. Meda 18 d'Abril de 1850

Ill. mo e Ex. mo Snr. Conselheiro Presidente

Da Relação do Porto

O Juiz de Direito

José Januário Teixeira Leite de Castro ${ }^{175}$

\section{Doc. 10}

\section{Segunda resposta de Leite Castro}

\section{Senhora}

Em 17 do mez que findou recebi um officio do Conselheiro Presidente da Relação d'este distrito accompanhado d'um papel, sem data nem assinatura de pessoa alguma, que contra mim contém arguições que se verdadeiras fossem offenderão a minha honra que de meus paes recebi e conservo sem mancha.

Duvidei /por falta d'assinatura/ responder, assim o expus em data de 18 do mez passado ao Presidente da Relação que me desse remeter o tal papel no mesmo estado que pelo governo lhe fora mandado sem se me ordenar respondesse ou não, encarregando-se ao mesmo tempo de informar o principal manobrador da delação que tenho razões para crer é Miguel Jerónimo Pinto Teixeira, juiz substituto a quem eu anullei os inventários mandados por elle fazer na cabeça do julgado, condenando-o a satisfazer aos interessados, as custas e prejuizos que lhe motivou.

Mais Senhora nos dias d'oje tudo assim marxa contra os que bem servem á Vossa Magestade e ao paiz!

Incrivel parece que no século em que vivemos se tomasse conhecimento de uma delação anonyma, mas eu não costumo e mesmo não posso duvidar d'aquillo que vejo!

${ }^{175}$ In Iantt, MNEJ, maço 556/9. 
Respondo; Não devo consentir que quando se tracta da minha onra que mais que prezo mais do que a vida prezo, eu deixe isso a revelia. Fá-lo-hei respondendo com documentos e providencias remediando e castigando os abusos e roubos do meu principal acuzador e sócio.

Direi antes de tudo, o que sei, e é oje na camara publica a respeito por auctores da delação de que se tracta. Miguel Jerónimo Pinto Ferreira, homem / a todos os respeitos insignificantel é correlegionário político do actual governador civil da Guarda e do seu secretário, todos miguelistas furibundos, tratarão do modo de me incommodar e tirar da comarca, encarregando a Miguel Jerónimo e ao Administrador do Concelho, também miguelista e mariola de colherem e indagarem aos autos da minha vida que lhe parecessem menos legaes: estes assim o cumprirão. Esquecerão as invejas antigas que entre estes pois avia e cuidando-se mandarão a Guarda o Secretário da Camara, ladrão publico, como me será facilissimo provar com estas particulares a que alli derão a ordem por que se axão escriptas, alli foi sem serimonia um por empregar escripta de que alli for sem serimonia pela auctoridade paternal enviada ao Ministério do Reino. É o que a este respeito sei. Se a própria delação me tivesse sido e não a cópia, remettida, talvez se reconhecesse a lettra.

Por este ensejo direi qual o motivo d'indispozição d'estes miguelistas personagens, contra a minha umilde pessoa. Foi por eu lhe processar e mandar prender alguns dos assassinos e ladrões que elles em lugar de perseguir, protegião e assinavão. N'esta comarca a vizinhança, antes d'eu tomar conta da jurisdição, matava-se e roubava-se nas praças e ao meio do solsem que a contrário punissem os seus auctores. O calendário de mortes e roubos que no doc. ${ }^{\circ}{ }^{\circ} 1$ se tem, provão o que digo. A convivencia das auctoridades provão-no $\left(. .{ }^{176}\right)$ por ellas dadas, o acolhimento e amizade em que vivião com as assassinas e sem lhe fez. Eu sei Senhora, que as Só do Rafael da Figueira só the mandou embargar uma cavalgadura, para o conduzir até ao lugar dos Chãos quando hia na diligencia d'o matar. Quem o mandou embargar foi o honrado Administrador d'este infeliz Concelho: a cavalgadura era d' Anna Brilhante! Que mais é mister para provar a conivencia das Auctoridades Administrativas?

Eu devo, Senhora, nada occultar a Vossa magestade a fim de que o governo e paiz inteiro saiba quaes as auctoridades administrativas d'este mal fadado distrito. Em Villa Nova de Foz Coa e vizinhanças forão mortos e espancados os indivíduos constantes do documento $n .^{\circ} 1$. Mais de duzentas pessoas só d'aquella villa andarão/até a pouco/ expatriados. Os seus perseguidores colhião e arrecadavão os frutos das propriedades d'aquelles e nunca a tal Auctoridade administrativa e paternal deo a tal respeito uma única providencia. Taes auctoridades devião a muito ter ido, com a mesma coroa, enforcadas.

A minha inergia, Senhora, e o anno do nascimento bastará para eu restituirn a paz a minha comarca $e$ as gentes que confiara aos meus cuidados.

Chegou, a tanto, Senhora, o descaramento que José Formiga, por Charta foi prezo por Sebastião Coelho Macedo e outros d'Outeiro n'esta villa para ser arcabuzado não o foi por que José António a título de que hia xamar o confessor foi por ordem para que não o arcabuzassem, e quem a deo foi Luis Bernardo da Foiça.

Esperarão em quanto elle foi ao lugar do Poço do Canto onde se axa aquelle que tinha dado a ordem, e voltou com uma contra ordem para que o não matassem e o conduzissem prazo para Villa Nova para onde foi. Nem a audiência administrativa, nem a judiciaria derão no momento providencias algumas, nem depois conhecerão.

Inevitavel isto parece, ahi está porem toda a Villa e que diga se isto é ou não verdade.

Depois que eu tomei conta da jurisdição, tomarão as coizas nova marxa. O assassino e salteador e o perturbador não era infalivelmente punido, acuso provar. Ameaças de morte, esperas e ${ }^{177}$ ouve para tal fim, contra mim, mas nada me fez vacilar no exacto cumprimento dos meus deveres para o que sempre me subejarão forças.

É-me dezagradável dizer estas coizas, mas eu sou a isso provocado e é a culpa de quem me provocou. De mais eu posso dizer a Vossa Magestade a verdade agora, eu fora a quem ferir para em presença de

\footnotetext{
${ }^{176}$ Vocábulo ilegível.

${ }^{177}$ Ibidem.
} 
tudo se poder fazer o paralelo entre a dezordem e a paz; entre a costação e a inteireza; entre a justiça e a injustiça. A justiça, Senhora, não se administrava, vencia-se como depois farei com documentos, ver.

Vou responder as arguições que me são feitas.

Nunca em tempo algum mandei prender testemunha alguma por não dizerem o que eu pretendia, por que eu nada, além da verdade, d'ellas fallarem, mandei sim é verdade prender duas, ou mais testemunhas de Casteição, mas foi por insistirem, d'um modo atrevido em dizerem não juravão o que sabião d'ouvir, por que não acreditavão no que ouvião, não sou surdo por maneiras possivel convence-las de que devião jurar o que tinhão ouvido, embora não o acreditassem: E com muito boas tenções estava d' os processos se me não viessem dizer juravão o que tinhão ouvido. A gente d'aquella freguezia é muito rústica e muito má, e estavão na usança de dizerem nada sabião embora os crimes se commetessem, ao meio dia e nas marcadas como entre outros foi o assassinato feito na Granja pelo Farinho, assassino por Marçães e não o pronunciarão! Creio aver obrado como o cazo previa. Ou queria o Snr. Miguel Jerónimo, meu delator eu fizesse como elle uzava fazer? Queria que eu não deligenciasse descobrir uma rezistência feita no meio d'uma povoação e ao meio do dia a dois empregados do juizo? Queria, bem o sei, mas não o permitia a justiça. Algumas d'ellas tinham sido referidas: um Nicolao, Ayres e mulher d'este que é filha do seu alfayate. Esta mulher, agora xamada pelo juiz substitutoautor da delação e encarregado d'informar disse que sabia tudo o que estava n'aquelle papel /deferindo-se a conta por que era interrogadal por que o Snr. Abbade Lhe avia dito!

O Abbade Senhora, é o pae, tio ou padrinho ou o que quer que seja, da mulher do denunciante que esta encarregara d' informar! É estava na freguesia de Casteição donde as testemunhas são, mas rezide quaze sempre em Outeiro dos Gatos nas casas que deo á afilhada ou filha cazada com o juiz denunciante e infamante.

Não lhe dirigi, nem mesmo era possivel dirigir as testemunhas as explicações que na delação se dizem, por que são expressões que a minha edocação não concente eu dirigisse jamais a ninguém. É verdade os hirem os prezos para a caza que serve de prizão n'esta villa, em quanto não vão para a cadeia de Marialva. E é igualmente verdade ser a prizão uma loja. Será isso culpa minha em não aver melhor prizão aonde recolha os prezos? E onde os tinha o Snr. Miguel jeronimo, Juiz substituto e outros juizes?

Só agora sei que os officiaes se pagarão e quanto, e eu não posso remediar o que não sei.

Segunda arguição

É verdade o mandar eu prender uma orfã do rabaçal, Máxima de jesus, por aver fugido em a n oute de Natal de 48 de caza de seu tutor e sair para caza do raptar aonde passados dias da sua fuga, foi encontrada; mandei querelar ao raptor. O tutor veio queixar-se, e não queria que a orfã que tinha oito mil réis de legitima cazasse com o raptor, que pouco tinha, e era além d'isso d'uma familia avida por ladrões.Foi para Trancoso para estar mais retirada do perigo, e por que assim o previo o Tutor que alli tem parentes e amigos.

Se acazo se prostituio, que culpa posso eu ter n'isso? Eu fiz o que as circunstancias me aconselhavão envieia para longe do perigo. Fiz o que devia fazer um juiz, e mesmo um pae cuidadozo na dignidade e honra de suas filhas a quem ellas tão ordinariamente enganão.

Tinha sua graça de os juizes se tornarem responsaveis pela má conduta das órfãs d'uma comarca!

O Snr. Miguel Jerónimo, autor da conta, queria que eu como elle fizesse. Queria que eu me deixasse sobornar pelo pretendente d'orfã contra a mesmo do Tutor, e mesmo sem o ouvor autorizasse o cazamento como elle fez com a orfã Candida Joaquina de Longravia que sem seu pae e tutor querer, sem o ouvir, sem conhecer das conveniencias do cazamento, sem mesmo o pai saber apareceo cazada : Documento $n^{\circ}$ 2. dizem as más linguas que o Snr. Miguel Jerónimo, juiz substituto, juiz delator, juiz infamante levou rasca para assim dar a licença.

Snr. Miguel Jeronimo não avalie pelo seu o meu proceder.

Terceira arguição

Nunca insultei nem mal-tractei jury algum. Nunca lhe ditei nem insinuei nem directa nem indirectamente suas respostas aos quezitos. E sendo assim desnecessario seria annular-lhas por iniquas, como 
succedeo uma única vez em um crime de morte cruelmente feita. Mais d'um direito que o Art. 542 t. 3 da Ref. me dá.

O Snr. Miguel Jerónimo axou novo este meu proceder, por que elle servisse de juiz/como o Réo d'essel estava servido. Era assim ou não? Que fazia o IIl. Delegado do procurador Régio, ou o deffensor do réo quando eu ditava as resposta aos jurados? Outro officio Snr Miguel Jerónimo, o offício do seu pae que não assiste estes comprometimentos.

Quarta arguição

O Snr. Miguel jeronimo como soubesse que damazia filha de benedicta tinha vindo a juizo declarar que nunca fora testemunha e não for a por mim insultada, mandou chamar a outra irmã Margarida que também não foi testemunha no processo que me consta dizer e fora (documento $n .^{\circ}{ }^{4}$ ). Saiba-se que a caza da mãe d'estas raparigas é onde o Miguel Jerónimo vai puzar quando vem a Meda e cuja familia tem acreditado pouco!

Quinta arguição

Nunca desde que sou juiz, mandei fazer deposito aos reos para se livrarem nem das partes recebi jamais emolumentos alguns, recebo o que me é contado e recebo-o da mão d' escrivão. Roubei-o a minha conta.

Isto tanto nos processos crimes como nos civeis e orfanoologicos que só depois de ultimar as contas é que me vão pagar. E quantas vezes é necessário esperar ainda as partes?

Não me consta também que os escrivães recebão dinheiro às custas das partes por que me lembro de que um cabeça de cazal recebendo no marcado que todos os mezes na Villa se faz, quis dar a conta d'inventário para mandar ao escrivão e este veio consoltar-me se as deveria ou não acceitar. Foi o escrivão Silva: cabeça de cazal foi o Domingos da Quinta da Veiga.

Outra occazião succedeo que um réo do lugar d'Avellozo que foi um fulano xamado João só culpado em uma querela de ferimentos vende-se uma propriedade, e veio saber d' escrivão em quanto haveria importar a querella para lhe pagar. Veio o escrivão e o réo ter commigo e eu que conhecia o comprador disse-lhe deixa- se na mão d'este o que pouco mais ou menos visse, pelos outros querelar, poderião importar as custas. não é.

Quem assim obra não recebe as contas. Nem a isto se pode xamar deposito porque em verdade o

Não me constou que os réos pronunciados na querella de rezistencia fossem pobres, nem isso do processo consta e sei oje que todos tem mais ou menos. Sei agora que o Reverendo J. João António de Sousa pagou ao escrivão por alguns dos réos, por que estes lhe venderão generos para o seu livramento. Um dos reos vendeu ao abade, tio, pae ou padrinho da mulher de Miguel jerónimo. A fiança importou na quantia de 3:490 r. documento $n^{\circ} 5$.

Os affiançados ou seus fiadores jamais forão por mim obrigados a coiza alguma. Os termos são escriptos pelos escrivães da mesma forma que d'antes o erão, o processo para a fiança e como a lei o manda fazer. Documento $n^{\circ} 6$.

É verdade a ver eu notado em um processo crime do roubo das pratas da igreja da Trova o ter-se concedido fiança ao comprador e receptador dos objectos roubados e não obrigar o Juiz Miguel jeronimo o réo sendo de guimarães, a escolher do muito contra o que o Art. 931 da Ref. Dispoem. Documento $n^{\circ} 7$

Mas, senhora não pára só aqui a pouca vergonha e ladoreira, concedeo-se a fiança ao comprador dos objectos sagrados, concedeo-se ou antes vendeo-se como se ve no documento $n^{\circ} 8$ o juiz, Delegado o escrivão todos roubarão. Vergonha e dezonra da justiça.

Sexta arguição

Não é verdade porque eu tenho criados para hirem aceitar os requerimentos as partes. Como veio aggarvar o réo de lhe não conceder fiança quando no preparo de pronucnia já estava concedida a fiança? Documento $n{ }^{\circ} 9$ 
O tal cunhado do réo é barbeiro de Miguel Jerónimo o denunciante, é barbeiro a quem mandei suspender d'escrivão de juiz eleito da freguesia dos gatos.

Sétima arguição

É verdade o ter sido processado correiccionalmente o regedor da freguesia do poço do canto, mas por actos comemetidos fora d'exercicio das suas funções, por esperar com outro companheiro a António Joaquim satam e atirarem-lhe pedradas com que o ferirão na cabeça, quebrarão-lhe a porta e umas poucas de telhas. Condeneio em um mez de prizão e nas custas.

Processei afora este mais dois: um por por fogo ao povo; porem este não podia servir de regedor, por já estar pronucniado em uma querella de ferimentos, quando foi nomeado regedor. Outro foi por arrombar as 11 oras da noute, a porta da caza d'um cidadão, para o prender, por não ter meter guarda a cadeial ou lojala um prezo d'administração.

Tenciono fazer outro tanto aos mais que como este o merecerem. Acredite o Snr. Governador civil e companhia que eu não temo ou suas hiras miguelinas; bem como não receberei d'elle lições d'honra e probidade e não a pagar nada: pagou as custas do processo e sellos do mesmo em que o condemnei. O processo ahi está d'elle se pode ver a verdade.

Oitava arguição

Já fica dito que eu nunca em dias da minha vida recebi emolumentos sem serem os processos contados; nem me consta que os escrivães d'este juizo os recebão, por que todos tres me devem conceito. Desafio a todos os meus inimigos/ que só são os traficantes/ para que (... $)^{178}$ uma única pessoa que diga eu já recebi da mão das partes os meus emolumentos, ou mesmo o meu criado. Offereço a minha cabeça se o contrário do que digo, se provar. Confessome devedor d'esta justiça mesmo aos meus inimigos politicos.

O documento $n^{\circ} 10$ mostra que os processos por dois reos não chegarão à Rellação.

Annulei sim alguns inventários feitos pelo juiz substituto Miguel Jeronimo lauctor d'esta delação como ai consta/ e anullei porque segundo a lei não era elle quem os devia fazer, mas sim o juiz ordinario e que é feito por juiz incompetente é nulloe o que é nullo não pode produzir effeito. O que é mais, mandei-lhe restituir os emolumentos indevidamente recebidos que montão perto de quatro centos mil réis. Como o cavalo da batalha. E a couza principal d'esta delação. Coitado! Como ainda deixou para ultimo seu dezabafo! Como adverte em lugar de Miguel Jeronimo, diz Manoel Jeronimo! Coitado! É filho de um barbeiro não pode ser cavalheiro!

Em annulando os inventários por elle feitos em desempenho de meus deveres, tive em vista os meus interessesem prejuizo dos orfãos e elle fazendo-os contra a lei não foi com a mira nos emolumentos? Dos orfãos não tem elle a ter dó, por que aquelles que tenho annulado tem sido sem custar condenando a paga-los quem os motivou. Esta é que é a cauza da comissão do Snr. Miguel Jeronimo, juiz substituto, juiz delator, juiz infamante! Eu, Senhora, annulando os inventários por elle feitos cumpri uma lei, e elle fazendo-o ofendeo a lei e com semelhante proceder cauzou aos orfaos graves prejuizos e com as questões que já alli se movem e (... $)^{179}$ emolumentos ao juiz ordinario a quem por direito pertencião, eu pelo contrário remediei os males aos orfãos não cauzando prejuizos.

Décima arguição

Em quanto a lei obrigava os juizes a hirem assistir a (... $)^{180}$ e louvação fui sempre depois que na ultima reforma das tabelas se dispensou a sua assistencia, nunca mais fiz as arguições e não se me contão por essa razão emolumentos. Ahi estão os processos que melhor que o meu denunciante deixarão ver a verdade.

\footnotetext{
${ }^{178}$ Idem.

${ }^{179}$ Idem.

${ }^{180}$ Idem.
} 
Direi por ultimo que na comarca de Villa Pouca fui sempre tão estimado e bem quisto como o sou na de Meda com excepção dos gaiatos e tratantes como Miguel Jerónimo que já o condenei a repor o que, sem o fazer, o fez seu. A minha saída da comarca da Villa Pouca ouve lagrimas, não ouve foguetes. Por eu me nunca d'alli (.... ${ }^{181}$ todo o tempo que alli estive. Querendo saber se é isto assim pode dirigirse a comarca d'aquella villa e sente-se dezenganada.

Isso a meu rogar aos do meu delator na parte em que roga a Vossa magestade me transfira d'aquella comarca, mesmo para que elle como juiz substituto que não propuz, receba na suzencia dos juizes os emolumentos, e a mais que elle e alguem mais sabe.

Agora Senhora, resta-me cumprir com o que prometti ao Prezidente da Relação no meu officio de 18 do passado e foi o seguinte - que no tempo em que Miguel Jerónimo servio de substituto que foi desde maio de 1846 até hoje os assassinos matavão e roubavão impunemente, não ser condenados por muitos crimes e outros de que se conhecia por fim se concluião em bem, dando dinheiro.

Não se querellou da morte praticada na pessoa do José d'Oliveira de Casteição, de José Bernardo Rodrigues, do Moutinho, de José António d'Araújo d'Alcarva, da Trova, a quem Miguel Jerónimo fez exame, mas não ouve mais procedimento.

Principiou-se a querella da morte feita na pessoa de António Fontes, mas mandou tres moedas para o escrivão, e não sei quantas para o juiz deixou-se esta no estado vergonhozo que mostra o documento n. ${ }^{\circ} 11$. Sem se despaxar petição, sem se lavrar o auto da querella, as assentadas em branco, em branco os dizeres das testemunhas, e no fim as assinaturas das testemunhas que sabião escrever, documento $n{ }^{\text {os }} 11$ e 12 .

Não conheceu Miguel Jerónimo por ferimentos feitos com um tiro na cara de Camilo António de (.... ${ }^{182}$, e isto por lhe dar o tio do que deo o tiro , o (... $)^{183}$ dos Chãos, uma vitela já grande que o mesmo juiz creou em caza e depois vendo em marialva como é notório. Tudo aver o exame o conheci eu: documento $n .^{\circ} 13$.

Outro tanto succedeo com os ferimentos feitos no ferrador leitão de Malhados, que eu conheci já, por me vir a mão o exame. Documento $n .^{\circ} 14$.

O numero a respeito do processo de João Nicolao e outros vizinhos do tal Juiz Miguel jeronimo que não quis conhecer.

Vendião-se as querelas de morte, uma pelos escrivães e outra mesmo pelo delegado do procurador régio, e uma ouve que custou ao réo 36 moedas. Documento $n .^{\circ} 15$. D'isso não cuidava o juiz Substituto Miguel Jerónimo, cuidava só por inventariar e dão-lhe estes ainda hoje cuidado.

Disse que no tempo do substituto Miguel Jerónimo se pagavão inventários sem se fazerem, eu para que se não fizessem se pagava Documento $n .^{\circ} 16,17$.

Disse que o tal substituto Miguel Jerónimo não passou a jurisdição orfanologica para o juiz ordinario, fazendo-se os inventarios sob sua prezidenecia provisoria, por tal forma, o juiz ordinário dos emolumentos que lhe pertencião e trazendo às partes os (.... ${ }^{184}$ que já andão em juizo.

Isto confessa-o elle mesmo na prezente delação, não junto, por isso documento algum. O livro da distribuição mostra ter elle distribuido 101 inventarios de menores.

Disse que em alguns julgados da comarca os sub-delegados hião assistir a descripção e louvação dos bens dos orfãos, e levão diarias e o mesmo que o juiz. Documento $n .^{\circ} 18$. Este mesmo documento mostra que os escrivães levavão diaria as partes quando hiam a caza do juiz ordinario a algum fim que interessava a estes. Este documento mostra o mais que se fazia quando exercia jurisdição Miguel Jerónimo, ainda oje Substituto.

Disse que em alguns cartórios dos julgados se vencerão todos os processos crimes. Documento n. ${ }^{\circ} 19$.
${ }^{181}$ Idem.
182 Idem.
${ }^{183}$ Idem.
${ }^{184}$ Idem. 
Disse que nos julgados de trancozo, os empregados da justiça não davão andamento / por dinheiro/ aos processos crimes. Documento $n .{ }^{\circ} 20$.

Disse que o Sub-delegado de Penedono vendera um titulo de compra e a certidão da siza, ou antes vendera os autos a onde estes documentos estavão, e que respeitavão a uma orfã. Documento $n .^{\circ} 21$.

Disse que se concentia no tempo de Miguel Jeronimo que um escrivão tivesse serventuário, ou servisse por elle o outro companheiro, dando ao outro $3 \$ r$ por mez. Documento $n .^{\circ} 22$. O escrivão era José maria Sá que já foi demitido por ser assassino e ladrão.

Disse que o dinheiro das multas do juizo tinha sido vil e vergonhozamente sorrepiado. Documento $n^{\circ} 23$ e 24.

Disse que Miguel Jerónimo consentio que o escrivão José Botelho de Carvalho Junior servisse até maio de 1848 o oficio d'escrivão de que tinha sido demitido a muito. Documento $n .^{\circ} 23$. Consentio também que o juiz ordinario estivesse exercendo jurisdição até que eu d'elle tomei conta, não obstante serlhe ordenado pela Presidencia da relação a passasse ao substituto em razão do contador do juizo ser filho de Mathias Hipolito, primeiro juiz ordinario. Documento $n .^{\circ} 26$.

Disse que Miguel Jeronimo mandara passar uma deprecada para serem presos um réo da villa Nova de Foz Coa sem ser pelo escrivão do processo nem pelo do juizo, mas sim por uma letra e pessoa particular e isto depois d'eu já aver tomado conta da jurisdição. Documento $n .^{\circ} 27$.

Disse que Miguel Jerónimo Pinto Ferreira mandara sem cauza nem motivo suspender o escrivão Salvador António de Seixas, e nomear para o substituir Sebastião Maxado Coelho d'Azevedo, hirmão d'outro escrivão do mesmo juizo de Marialva. Documento $n .^{\circ} 28$.

E isto sendo o (... $)^{185}$ para o substituir além d'hirmão d'outro escrivão, matador e ladrão. Documento $n .^{\circ} 29$.

Disse que Miguel Jerónimo consentio que o escrivão Botelho, ladrão como o $(\ldots)^{186}$, fizesse as escripturas sem distribuição, que pessoas particulares escrevessem no Livro das notas, e o mais que do Documento $n .^{\circ} 30$ consta.

Disse que Miguel Jerónimo permittia que o escrivão José Botelho processasse os inventários em papel por sellos e recebendo das partes o dinheiro dos sellos, e a fazenda ficou a perdendo, ou está ainda sem os receber. Documento $n .^{\circ} 31,32,33$.

Disse mais que Miguel Jerónimo quando servio de substituto dispunha do dinheiro dos orfãos sem consentimento dos tutores, emprestando-o a quem com elle se sabia intendre sem que os devedores dessem fiador, sem escripturar e sem hipoteca. Documento $n .^{\circ} 34$.

Tudo o mais, Senhora, tandava por este gosto, tenho pouco a pouco $(. . .)^{187}$ em remédioss tantos males, por cujos serviços não aguardava louvor, por que só cumpria os meus deveres, mas também não esperava esta paga.

Termino minha resposta.

Meda 30 de Maio de 1850

O Juiz de Direito

José Januário Teixeira Leite de Castro (com 34 documentos) ${ }^{188}$

\title{
Doc. 11
}

\section{A exposição da Presidência da Relação do Porto de 30 de Julho de 1850}

\section{Ill.mo e Ex.mo Senr.}

Tenho a honra de levar ao conhecimento de V. Ex. ${ }^{a}$ as diligências a que se procedeu acerca das arguições feitas ao Juiz de Direito da Comarca de Meda José Januário Teixeira Leite de Castro, assim no

\author{
${ }^{185} \mathrm{Idem}$ \\ ${ }^{186}$ Idem. \\ ${ }^{187}$ Idem. \\ ${ }^{188}$ In Iantt, MNEJ, maço 542/5.
}


papel sem assinatura, como no auto de investigação do Administrador do Concelho de Figueira de Castello Rodrigo, e sobre as quaes fui mandado informar por Portarias Régias do $1^{\circ}$ de Abril e 14 de Maio proximo passado, depois de o ouvir por escrito.

Accuzão aquelle Juiz de ter injuriado, ameaçado, e mandado prender na loja da caza da Camara alguas testemunhas por não jurarem o que elle quer, e por dizerem que seus depoimentos não se achão escriptos, como por elles forão dictados, levando-lhes os officiaes custas por taes diligencias, e appontão os processos e as testemunhas, com quem tiverão lugar taes excessos. - De ter insultado, e injuriado com grande acrimonia no segundo semestre de 1849 a um Jury, por não dar por provados os quezitos, de pois de lhes dizer que o estavão, e por ter convocado outro, que só por medo dera tudo por provado. - De não admitir a livramento os culpados sem depozito, obrigando os ricos pelos pobres, e com excesso de emolumentos e sallarios, especificando-se um processo, em que isso tivera lugar. - De mandar prender uma orfãa na cadêa de Penedono distante de casa, quatro légoas, pelo simples facto de querer caar contra a vontade do Tutor, dano com isso ocazião á sua desgraça, por ter ahi contrahido amizade illicita. - De ter ameaçado com procedimentos aos Empregados Administrativos no exercício de suas funções, e de os processar e prender sem licença do Governo; e ppontão-se alguns desses procedimentos, e por que occazião tiverão lugar. - E finalmente é mais accuzado de ter annulado, só por interesse proprio, os Inventarios, que fizera o Juiz Substituto, durante a vacatura do proprietário; e de ter levado emolumentos pela assistencia á descripção de bens, sem a ella ter assistido.

Para conhecimento da verdade sobre taes representações ordenei ao $1^{\circ}$ Substituto d'aquelle Juizo de Meda, que inquirisse testemunhas e procedesse ás mais diligencias necessarias, como exames nos processos, mas conhecendo depois pela resposta do juiz accuzado que entre este e aquelle havião insdispozições que o tornavam suspeito, transmiti aquellas diligencias ao segundo substituto para verificar a exactidão das mesmas, e proceder ao mais necessário.

Por uma e outra diligencia vê-se, que o primeiro Substituto só inquiria por testemunhas pessoas que se dizem offendidas pelo Juiz arguido, e que não procedera aos exames necessarios, e que o segundo substituto inquirira testemunhas mais qualificadas e desinteressadas e que procedera a outras diligencias, ainda que não a todas as necessarias.

E de tudo, e resposta documentada do juiz parecesse, que se pode concluir, que o juiz accuzado para com todos tem sido forte, talvez em demazia, podendo conseguir o mesmo por meios mais suaves e legaes, porem não que tenha levado emolumentos excessivos, por que isso não se prova, nem ordenado o depozito de custas para o livramento dos culpados, ou que os sallarios dos officiaes de diligencias, de que fallão as testemunhas da primeira inquirição, fossem com conhecimento seu, quando não fossem devidos, ou excessivos.

Pelos documentos e resposta do juiz, mostra-se que alguns dos procedimentos contra Empregados administrativos forão authotizados e que outros forão excessivos; assim como se provaque aquella Comarca quando para ali fora, estava em dezordem e anarchia, e que hoje se acha em milhor ordem.

Em quanto a Inventarios é sem duvida, que annulara os que havia feito o Juiz Substituto, durante a vacatura do juiz proprietario; e que condemnara aquelle Juiz Substituto nas custas dos mesmos, de que tem vindo recursos ao Tribunal da Relação. O meio de que se servio para o fazer, não me parece legal.

V. Ex. ${ }^{a}$ rezolverá o que lhe parecer de Justiça.

Deos Guarde a V. Ex. ${ }^{a}$

Porto e Prezidencia da Relação em 30 de Julho de 1850

IIl.mo e Ex.mo Senr. Ministro e Secretário de Estado dos Negócios Eccleziasticos e de Justiça

O Cons. ${ }^{\circ}$ Prezidente da R.am

Bernardo José V. ${ }^{a}$ da Motta ${ }^{189}$

189 Ibidem. 


\section{Doc. 12}

\section{Parecer do Procurador da Coroa, de 31 de Março de 1851}

\section{Senhora}

Revertem À Augusta Presença de Vossa Magestade os papeis concernentes às arguições feitas ao Juiz de Direito da Comarca de Meda, José januário Teixeira Leite de Castro, e interpondo sobre elles o meu humilde parecer, em cumprimento da Determinação de Vossa Magestade na Portaria expedida a esta Repartição pelo Ministério da Justiça, repartição da mesma, em data de 5 de Agosto do anno proximo passado, tenho a honra de declarar a Vossa Magestade que examinando cuidadosamente, $e$ confrontando entre si as averiguações, quer judiciaes, quer administrativas, a que se mandou proceder pelo Ministério do Reino em Portaria dirigida ao Governador Civil da Guarda em 19 de Março, e pelo Ministério da Justiça em Portarias expedidas à Presidência da Relação do Porto, em data de $1^{\circ}$ de Abril e 14 de Maio do predito anno, não pude, e creio que ninguém poderá, formar um juizo seguro sobre a veracidade dos factos extra-legaes e alguns qualificados criminosos por Lei, attribuidos ao referido Magistrado no exercicio de suas funcções judiciaes na indicada Comarca; factos extensamente dedusidos; assim na Representação anonima, como na do Administrador do Concelho de Meda, dirigidas ambas ao Ministério dos Negócios do Reino em Março do anno findo.

Pois que as indagações, a que procedeu o segundo Substituto do Juiz de Direito na dita Comarca, José Cardoso Pinto Leitão, coherentes com a resposta documentada do Juiz arguido, e às quaes a Presidencia da Relação do Porto deu maior crédito em sua Informação, contrastam perfeitamente com as anteriores, a que do mesmo modo procedera o primeiro Substituto daquella Comarca Miguel Jerónimo Pinto Ferreira, que o juiz arguido suppoem ser o autor da Representação anonima, bem como com a Investigação, a que procedera também o Administrador do concelho de Figueira de Rastelo Rodrigo, Francisco da Guerra Bordalo da Foncêca, na qual o Governador Civil da Guarda funda a sua Informação. Nestas ouvidas varias pessoas, que depozerão de facto proprio, mostra-se o Juiz increpado vergando debaixo do pezo enorme de uma responsabilidade immensa por numerosos actos despoticos, arbitrarios e criminosos com escandaloso abuso de seu respeitável ministério: naquellas, consultados os caracteres, que pareceram mais qualificados e fidedignos por sua sisudez, independencia e imparcialidade, apparece o mesmo juiz a salvo de todas essas violentas recriminações, forjadas, segundo elle presume, pelo ignobil sentimento de vingança do seu primeiro Substituto Miguel Jerónimo, contra o qual em reconvenção apresenta um catálogo infinito de malversações escandalosas, por elle e outros empregados commettidos em quanto a Comarca esteve sem Juiz proprietario.

No meio pois de tão encontradas informações, que produsem no meu animo a maior dúvida e perplexidade sobre a precedencia das arguições feitas ao Juiz de Direito, de que se trata, assim como sobre a das que elle retribue ao seu presumido delator, eu julgo absolutamente necessario e indispensável mandar-se novamente informar a este respeito a Presidencia da Relação do Porto, ordenando-se-lhe mais positivamente, que encarregue ao Juiz de Direito d'uma das Comarcas mais próximas à de Meda e não a nenhum dos Substitutos do juiz de Direito desta, a escrupulosa indagação de umas e de outras arguições, e que ao mesmo tempo lhe recomende, se haja nesta diligencia com o maior acerto e circumspecção, não se limitando a inquirir as pessoas que tenham sufficiente rasão de sciencia de cada um dos factos, e sejam comtudo insuspeitas, e dignas de credito por sua probabilidade, e sã consciencia, mas procedendo também aos convenientes exames nos processos, e livros respectivos, que se apontam em prova de taes arguições, e praticando tudo o mais, que o seu zelo lhe sugerir, tendente a descobrir a verdade, em ordem a que, não folgue o crime na impunidade, quando realmente o haja, nem gema tão pouco a innocencia opprimida pela calumnia de ignotos delatores quando aquelle não existe.

Digne-Se portanto Vossa Magestade Mandar proceder a novas indagações na forma exposta e para então reservo emittir a Vossa Magestade com a minha costumada franquesa o parecer que a consciencia me dictar á vista do resultado d'essa nova indagação.

Procuradoria Geral da Coroa 31 de Março de 1851. 
O Ajudante do Procurador Geral da Coroa Joaquim Pereira Guimaraens ${ }^{190}$

${ }^{190}$ In Iantt, MNEJ, maço. 